\title{
BLACK SEA REGION IN WORLD POLICY: ACTORS, FACTORS, AND SCENARIOS OF THE FUTURE
}

\author{
MONOGRAPH
}

Editors Olga Brusylovska, Volodymyr Dubovyk, and Igor Koval

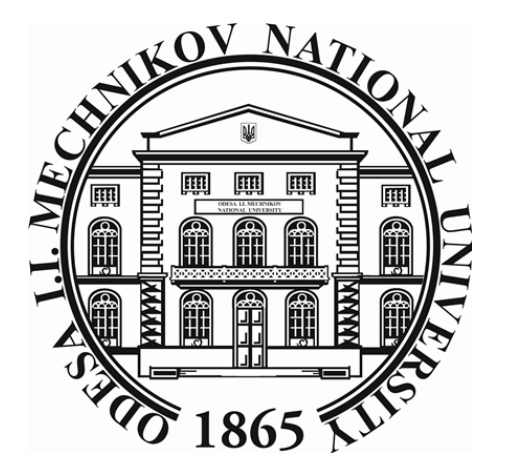


Brusylovska, Olga, Dubovyk, Volodymyr, and Koval, Igor (eds.),

Black Sea Region in World Policy: Actors, Factors, and Scenarios of the Future (Odesa: Odesa Mechnikov National University Press, 2020. - 168 p.).

Odesa Mechnikov National University Press is a department of the Odesa Mechnikov National University.

Odesa Mechnikov National University

Dvoryanska, 2

65082 Odesa

Tel: $+38 / 048 / 723-52-54$

Fax: $+38 / 048 / 723-35-15$

Email: rector@onu.edu.ua

http://onu.edu.ua/en/

Published in Ukraine by Odesa Mechnikov National University Press

Elisavetynska, 12, Odesa, 65082.

Published with support by Fulbright Ukraine

Proofread by Valeriia Lozova

All rights reserved. No part of this publication may be reproduced, stored in a retrieval system, or transmitted, in any form or by any means, without the prior permission in writing of Odesa Mechnikov National University. You must not circulate this work in any other form and you must impose this same condition on any acquirer.

ISBN 978-617-689-406-3

(C) Odesa Mechnikov National University

ISBN 978-617-689-407-0

Press 2020

DOI $10.18524 / 978-617-689-406-3$ 


\section{TABLE OF CONTENTS}

PREFACE

4

(Igor Koval)

CHAPTER 1. STRUCTURAL REALISM VS CONSTRUCTIVISM?

MODERN SCIENTIFIC APPROACHES TO THE STUDY

OF THE BLACK SEA REGION 6

(Olga Brusylovska)

CHAPTER 2. TURKEY'S POLICY IN THE BLACK SEA REGION:

THE BALANCE OF POWERS, THREATS AND INTERESTS

(Yevgeniya Gaber)

CHAPTER 3. ANNEXATION OF CRIMEA: LEGAL

AND SECURITY PERTURBATIONS 46

(Sergii Glebov)

CHAPTER 4. THE RUSSIAN BLACK SEA FLEET: IS THERE

A PLACE FOR STRATEGIC DIMENSION?

(Polina Sinovets)

CHAPTER 5. THE EU'S POLICY TOWARDS THE BLACK SEA

REGION: CLASH OF INTERESTS, RESPONSIBILITY

AND THREATS 80

(Iryna Maksymenko)

CHAPTER 6. NATO IN THE BLACK SEA: TRANSFORMATION

OF APPROACHES AND TAILORED PRESENCE 96

(Hanna Shelest)

CHAPTER 7. FEATURES OF THE MODERN APPROACH

OF CHINA TO THE BLACK SEA REGION COUNTRIES

(Olga Brusylovska)

CHAPTER 8. THE STATES OF THE BLACK SEA REGION IN JAPAN'S FOREIGN POLICY: HISTORY AND MODERNITY (Violetta Udovik)

CONCLUSIONS 158

(Igor Koval) 


\section{PREFACE}

Political, economic and cultural borders are usually different from geographical ones; this also applies to the Black Sea region. Only six countries border the Black Sea: Bulgaria, Romania, Ukraine, Russia, Georgia and Turkey. But the Charter of the Organization of Black Sea Cooperation (BSEC) was also signed by Albania, Moldova, Azerbaijan, Armenia and Greece. Moldova can be geographically considered a part of the Black Sea region, as it is located between Ukraine and Romania and is close to the Black Sea. Greece is close to the mouth of the Bosporus, which connects the Black and Mediterranean Seas. Armenia does not border the Black Sea, but is located near it. Two other countries are located on the shores of other seas connected to the Black Sea by many waterways: Azerbaijan (via the Caspian) and Albania (via the Adriatic). Therefore, the definition of the Black Sea is based on the signing of the BSEC, which laid the foundation for modern economic and political relations between 11 countries in the region.

However, the relevance of this monograph is primarily due to the fact that the BSEC has not become the main field of interaction for the Black Sea states. On the contrary, its current state can be bluntly described as "comatose". Therefore, this collective monograph is devoted, firstly, to identifying the behaviour of the main systemic and non-systemic actors that determine the development of the regional system of the Black Sea region, and, secondly, to identify factors that affect these actors in order to predict their behaviour in the medium term.

The purpose of the monograph is to identify the causes of the decline of the Black Sea regional system. The research dilemma can be formulated as follows: to what extent is this decline the result of the actions of the two regional leaders, Turkey and the Russian Federation, and to what extent is it due to non-systemic actors? Among the tasks is the identification of modern theoretical approaches that most adequately help to build a study of the dynamics of the Black Sea region. Also included in these tasks is the the identification of the following features: a) the policy of Turkey and Russia as regional leaders of the Black Sea region, b) the policies of the EU and NATO as the most influential international organizations, and c) the policies of China and Japan as non-systemic actors whose influence on the Black Sea is constantly growing.

The concepts of systemic and non-systemic actors are critically important for this monograph. Therefore, a systematic approach was chosen for the study, which in turn provided an opportunity to: 1) consider the object under study (the Black Sea) as a complex system of input and output signals, 2) to 
establish the connection of the system with its environment (world politics, which is manifested in the politics of major world actors), and to 3) specify the object of study (the Black Sea) as a system that is limited by internally defined relationships between elements. A systematic approach to the phenomenon includes the analysis of: 1) the elements that make up the system, 2) the patterns of the origin and development of the phenomenon, 3) its evolution, 4) the reasons for the changes, and 5) the essence and laws of its development. The application of the systems approach first enabled the division of the Black Sea into a number of subsystems (including lower level systems, such as regional leaders, EU newcomers, New Eastern Europe, and the South Caucasus), and then allowed for an analysis of the harmonization of each subsystem within the overall purpose of the system. It further allowed for a final construction of a systemic hierarchy, and the hierarchy of factors which make up this system and contribute to its functioning. A prominent place in the study is given to the study of direct and feedback relations of the Black Sea with the EU, NATO, China and Japan, which constitute the environment of the regional system under study.

Additional research methods were chosen, namely the prognostic method and the case study method; the selection of these methods provides for an opportunity not only to investigate individual cases, but also to apply the acquired knowledge in further scientific research on other cases. Scenario construction is a means of forecasting, which is used to predict the development of political events. This establishes a logical sequence of events, based on an existing or given situation. The scenarios focus on the connections between events and on the critical points where the effects can actually have an impact on the situation. Therefore, a study of the Black Sea's place in world politics would be incomplete without trying to provide potential scenarios for the coming decades.

The monograph focuses on the various developing relations in the Black Sea region, which over the years have been researched by the staff of the Department of International Relations of the Odesa I. I. Mechnikov National University. Accordingly, the work is structurally divided into eight sections, each of which covers a separate area of the foreign policy of international and national actors.

The work is designed for everyone who is interested in foreign policy and international relations - from students to experts. 


\title{
CHAPTER 1 \\ STRUCTURAL REALISM VS CONSTRUCTIVISM? MODERN SCIENTIFIC APPROACHES TO THE STUDY OF THE BLACK SEA REGION
}

\author{
Liberalism is a many-headed creature \\ (Jorgensen, 2010, p. 57) \\ Structures never tell us all that we want to know. \\ Instead they tell us a small number of big and important things \\ (Waltz, 1979, p. 72)
}

\section{Introduction}

The Black Sea region is a specific established structure in which the main actors are states (big and small) and supranational forces (EU, NATO, BSEC, etc.). In this view, it is not surprising that structural realism was chosen to study the Black Sea Region (BSR). However, this section also examines the liberal tradition of the study of international relations (IR), namely constructivism. This is due to certain gaps in structuralism that need to be supplemented by alternative theory.

Neorealists claim that great powers pay close attention to the balance of power and competition among themselves in order to gain power at the expense of others or at least not to lose their power/authority. They do so because the anarchic structure of the international system leaves them little choice if they want to survive. These competitions for power create a dangerous world in which great powers fight each other. Concentration on big states prompts a researcher that the provisions of structuralist theory may appear insufficient to analyze a region where most of the players are small states.

On the other hand, constructivists consider IR as a social construct; therefore they consider what can be changed by conscious actors in the process of their interactions. If realists operate with such basic concepts as "interests", "strength/power" and "balance", then constructivists raise the importance of "identity", "language" and "causality" in IR, which in our view is extremely important for understanding ongoing processes in the BSR, which has historically been a field of interaction of actors with different religious, cultural and ideological roots.

The problem is that both schools of scientific thought, although the most relevant for the analysis of modern international studies, are dissonant more 
than resonant, so it raises the question of their compatibility in the framework of integrated scientific research. Consequently, this section is aimed at clarifying what can be borrowed from each party so that their scientific ideas will complement each other while not violating the scientific unity of the research structure.

\section{Structural realism}

Realists from Hans Morgenthau to John Mearsheimer believe that power (strength, might, force) is the axis of international politics. It is important not only to have a significant amount of power, but it is also essential to be sure that no other state changes the balance of power in its favor. For realists, "international politics" is synonymous with "power politics".

Structural realism (neorealism) is a branch that, according to Knut Erik Jorgensen, is more complementary and innovative (first debate in the realist tradition), rather than simply a continuation of classical realism. They proceed from classical realism as a "starting point" and then largely sever ties with tradition (Jorgensen, 2010, p. 84). Instead, Barry Buzan (1993) and Glenn Snyder (1997) developed classical realism, enriching it with new variables "interaction" and "alliances" respectively (second debate). It should be noted that, according to Jorgensen, there are also post-neorealists who are closely related to the classical tradition and "revenge" neorealists for their separation from the foundations (third debate) (Jorgensen, 2010, p. 85).

Neorealists approve that the very structure of the international system forces great powers to seek authority. In a system where there is no higher power than big states, where there is no guarantee that one will not attack other, it is extremely essential to be strong enough to defend oneself in the case of attack. Essentially, big states are locked in a cage- they have no choice, so they must compete with each other for power if they hope to survive (Mearsheimer, 2013, p. 78).

In this sense, evolution of interstate relations in the Black Sea region can be a good illustration of the above thesis, because after the end of the Cold War and the weakening of Russia, the region became a showcase of the competing ambitions of the Russian Federation and Turkey. As they had failed to cooperate in the 1990s, there was less of a chance of Putin coming to power and reviving Russia's great-power claim.

It is important for our study to emphasize the weakness of structural-realism theory: it ignores cultural differences between states, as well as differences in the type of regime, because, in their view, the international system creates the same incentives for all. Whether a state is democratic or authoritarian, it has relatively little influence on its policies toward other states. The fact of who is responsible for foreign policy also does not matter much. 
Structural realists refer to states as "black boxes": they "must" be the same, except for the fact that some states are more influential than others.

In our view, without understanding the nature of the Russian Federation and Turkey, it is impossible to examine the evolution of their policies in the Black Sea region: many facts indicate the undemocratic nature of these regimes, which in turn complicates not only their bilateral relations but also relations with other relatively weaker states of the BSR. Therefore, at this point structural realism must be supplemented by the achievements of alternative theory.

Further analysis of structural realism revolves around the following main issues. Firstly, why are the great powers in international anarchy are afraid of each other? Secondly, what is the security dilemma and is there a solution to it? Thirdly, how much power do they want?

Structural realists base their thinking on five key assumptions (for them they are axioms) about the international system. The first of these assumptions: great powers are the main actors in world politics and they operate in an anarchic system (Jorgensen, 2010, p. 84). This does not mean that the system is characterized by chaos/mess; anarchy is the principle of order, which means that there is no centralized power or arbiter over states. The opposite of anarchy is hierarchy - the principle of organizing domestic policy. The second assumption: all states have some military potential; each state can do some harm to its neighbor. The third assumption: states can never be assured of the intentions of other states; states want to know whether other states intend to use force to change the balance of power (revisionist states) or whether they are sufficiently satisfied with it and they are not interested in using force to change it (status quo state). The problem with this specific assumption is that it is almost impossible to determine with a high degree of probability the intentions of another state. Unlike military capabilities, intentions cannot be verified empirically. Intentions are in the minds of decision makers, and they are especially difficult to distinguish. One could answer that policy makers disclose their intentions in assessable speeches and policy documents. But realists write that politicians lie (sometimes) or hide their true intentions (always). Even if it could be possible to determine the intentions of another state today, it is impossible to determine its intentions tomorrow. It is impossible to know who will conduct foreign policy in the country in five or ten years, and, moreover, whether they will have aggressive intentions or not. An actor can never be sure whether he is dealing with a revisionist state or a status quo state. The fourth assumption: the main goal of states is survival. States seek to preserve their territorial integrity and the autonomy of their domestic political order. They may pursue other goals, such as prosperity and 
protection of human rights, but these goals are always secondary to survival. Fifth assumption: states are rational subjects, i.e. they are able to develop reasonable strategies that maximize their prospects for survival (Mearsheimer, 2013, p. 78). However, of course, as states work with imperfect information in a complex world, they sometimes make serious mistakes.

None of these assumptions inherently suggest that states should compete for power. Realists believe: only when all assumptions are combined, there are circumstances when states are not only concerned about the balance of power, but also gain powerful incentives to gain power in the fight against others.

Let's start with the fact that states are afraid of each other, worried about the intentions of other states because they are so complicated to guess. Their greatest fear is that another state may have the ability and motive to attack them. The level of fear between states varies, but it cannot be reduced to an insignificant level; the stakes are huge. International politics is a case where there is a constant possibility of war, which often means mass murder on and off the battlefield- which can even lead to the destruction of the state. This danger is increased by the fact that states operate in an anarchic system; this means that there is no "night watch" that could save them if they are threatened by another state. If there is no higher power to which they can turn, this does not mean that states can form alliances that are useful for fighting dangerous opponents. After all, states have no choice but to put their interests above the interests of other states, as well as so-called international community (Mearsheimer, 2013, p. 79).

Fearing other nations and knowing that they are operating in a world of self-help, states quickly realize that the best way to survive is to be powerful. The argument here is straightforward: the stronger the state, the less likely it is to be attacked. This simple logic encourages large powers to look for opportunities to change the balance of power in their favor. Of course, every state in the system understands this logic, which leads to continuous competition for power. In essence, the structure of the system forces every great power to think and act as necessary as a revisionist state. One might think that peace should be possible if everyone is satisfied with the status quo. The problem, however, is that states cannot be sure of each other's intentions, especially future intentions. Today it may be the status quo, but tomorrow it may not be the same. In an anarchic system, where there is no final arbiter, states that want to survive have no choice but to assume the worst intentions of other states and fight them for power (Mearsheimer, 2013, p. 80).

This is the tragedy of great-power politics. And as was mentioned above, in modern Russia the ideology of great power was artificially (from 
above) revived; therefore, its next policy in the BSR is a confirmation of the negative consequences of such policy for itself (economic losses, aggravation of relations with the USA, NATO and EU). In effect, Russia does not control the situation, but rather is its hostage.

The structural imperatives, which are described above, are reflected in the well-known concept of the security dilemma. The essence of this dilemma is that most of the steps taken by a big state in order to increase its own security reduce the security of other states. For example, any country that improves its position in the global balance of power does so at the expense of other states that lose relative power. In this zero-sum world, it is difficult for a state to improve its chances of survival without threatening the survival of other states. Of course, under threat of extinction, states do whatever is necessary to ensure their survival, which threatens other states.

All realists agree only on the conclusion that nuclear weapons are of little use for offensive purposes, except when only one side of the conflict possesses them. The reason is simple: if both sides have the appropriate abilities, neither of them will benefit from the first blow. Moreover, both camps agree that a normal war between nuclear-weapon states is possible, but unlikely because of the danger of escalation to the nuclear level.

But there are great differences among realists. Especially in terms of how much power the state should seek.

Defensive realists acknowledge that the international system creates strong incentives to gain additional power, but argue that it is strategically unwise to pursue hegemony. It means over-expansion, which will lead to worse consequences. Instead of maximizing power, states should strive for what Kenneth Waltz called the "appropriate amount of power" (Waltz, 1979, p. 40).

"Theory of International Politics" (1979), written by the aforementioned Waltz, is a fundamental text of structural realism and, perhaps, the most influential book written in the field of international relations of the last half-century. Jorgensen called it "the best product of rationalist thinking" (Jorgensen, 2010, p. 84). Waltz's main thesis is that the lack of higher power to which great powers can turn in times of crisis, combined with their interest in survival, leaves states without choice but to fight for power with each other. It makes sense to have more power than your opponents if you have to rely on yourself when problems arise. After all, stronger states are less prone to attacks than weaker ones. Waltz, however, claimed that states should not try to maximize their power, because attempts to gain more power can easily lead to the opposite result. They certainly should not strive for hegemony. Actually, their main goal should be to ensure that other states do not gain power at 
their expense. The first concern of states, he emphasizes, is not in maximizing power, but in preserving their positions in the system. In addition, Waltz did not assume that entering the war to gain power makes strategic sense. The state must curb its appetite for power, Waltz argues, because of the predominance of balanced behavior. States almost always check competing states that seek to become particularly powerful. States which feel threatened can create their own capabilities, an "internal balance" or unite and form a balancing coalition - "external balance".

"Theory of International Politics" contains several other important ideas. Waltz argues that bipolar systems are more peaceful than multipolar ones. Based on systemic principles, from the standpoint of which the polarity of the system is considered as its structural characteristic, Waltz showed that the foreign policy behavior of states depends on the so-called "systemic tension". There are certain "systemic restraints" between states, which ultimately determine their foreign policy. This is the reason for the different levels of state involvement in world politics. Therefore, in order to understand or try to predict the behavior of states in the international arena, it is necessary to take into account the features of the international system and the specifics of its structure. This category especially, according to Waltz, gives an understanding of how the positions of states differ from each other and how they relate to each other in terms of their ability to act (Waltz, 1979, p. 80). In particular, the international system in a bipolar world is far more suppressing of its constituent parts, while in a multipolar system states have more freedom for military alignment (Waltz, 2001, p. 158).

For example, the structure of the world system during the Cold War required a clear definition of foreign policy orientation and joining one of the two hostile blocs, which significantly limited the ability of regional states to conduct an independent foreign policy. Unlike the bipolar system, in a multipolar system the choice of allies is no longer clearly defined by the structure of the system, but instead is largely determined by the national interests of each state, which significantly expands its range of partners and opponents and allows it reconsider its place in international relations.

Thus, if during the bipolar periods the system imposed strict restrictions on its structural units and significantly limited their actions, then with the collapse of the USSR the space for foreign policy maneuvering for small and medium-sized states was significantly expanded. This tendency to intensify foreign policy activities is clearly followed, in particular, by the example of Ankara's policy in the Black Sea region.

Structural changes in the system occur extremely rare, so in 1991 there was a unique chance to redistribute functions between its members. In par- 
ticular, for Turkey it was an opportunity to change the principle of relations with the United States from a "subject-object" model to a "subject-subject", at least in a regional context. Under the new world order, the level of systemic "tension" became much lower, the effect of structural restrictions on foreign policy-making by regional states weakened, and Ankara was objectively able to pursue a more diverse, multi-vector policy which often ran contrary to US interests. According to the logic of the neorealists, in such conditions the main motive of Turkey, as well as any other regional state, is the desire to balance the forces of the most powerful state (USA) by uniting with other participants of the system (primarily Russia).

Even for Kenneth Waltz in his early works, the policy of balance of power, which was expressed in increasing one's own power or creating alliances, is not the only possible policy. Other strategies are open to a country - for example, it can join a stronger state or, conversely, it can seek a leadership position. Waltz also recognizes that in a hierarchical system, "secondary states" are more motivated in increasing their absolute benefits (even if they are slightly smaller than other members of the system). And for this they are likely to move to the side of more powerful states (Waltz, 1979, pp. 161-194). In practice, this means that when there is an opportunity to "pass the buck to the shoulders of another", most countries will take this opportunity to reduce the risks and costs that are inevitable in balancing (Posen, 1984, p. 64).

Waltz also introduced an important distinction between balancing and "bandwagoning". The latter will be inherent in a state that joins forces with a rising state that wins wars and gains power. He claims that balancing is a behavior caused by the system, because states do not want to be vulnerable. Finally, Waltz argues that cooperation between states is complicated by fears of "relative benefits". It is difficult to conclude agreements because states are concerned that the other side will get more and shift the balance of power in their favor.

Thus, according to Waltz, the restraint of states is the result of three factors. If any state becomes too strong, the other great powers will create their own armed forces to balance and form coalitions. This will in turn leave the hegemon less secure and possibly even destroy it. Even when conquest is implemented, it does not pay: the costs outweigh the benefits. Because of nationalism, it is especially difficult, and sometimes impossible, for a winner to properly subdue the defeated foe. The ideology of nationalism, which is widespread and powerful, is based on self-determination, which effectively guarantees that the occupied population will rise up against the occupier. In addition, it is difficult for foreigners to exploit a modern economy, mainly because information technology requires openness and freedom. In general, it is 
difficult to truly conquer a foe- but even in the rare cases where large powers do conquer another state, they gain little benefit and many troubles. These basic facts about life in the international system should be obvious to all states and should limit their appetite for more power. If all states recognize this logic - and they should do so if they are rational actors - security competition should not be especially intense, and there should be few conflicts involving all or almost all major powers (Mearsheimer, 2013, pp. 82).

Waltz, realizing the incompleteness of his answers to the main questions of the IR, argued that his "theory of international politics" should be supplemented by a separate "theory of foreign policy" that could explain the erroneous behavior of the state. But D. Fearon noted that Waltz aimed to explain the behavior of the state, its various variants (balancing, bandwagoning, and seeking relative or absolute gains), so in this sense, structuralism is a theory of foreign policy (Fearon, 1998, p. 290).

It should be also noted that this "additional theory", which, according to Waltz, should turn to the analysis of domestic political factors, no longer fits into the theory of structural realism. In other words, we must find other theories to answer the questions that troubled Waltz.

Later, defensive realists such as Barry Posen, Jack Snyder, and Stephen Van Evera confirmed that without an alternative theory, it would not be possible to explain the cases in which the great powers acted in non-strategic ways. For this purpose, Posen (1984) relies on organizational theory, Snyder (1991) - on the type of internal regime, and Van Evera (1999) - on militarism. Stephen Walt (1987) paid great attention to social factors and created the concept of "balance of threat", which led to the inclusion of important variables of state behavior such as "consciousness" and "self-awareness". Walt and Snyder both showed in their research how political elites become hostages to their political rhetoric. Also, their empirical studies included intangible and internal factors. Jack Snyder (1991), Colin Elman (1996), Samuel Huntington (1996), Henry Nau (2002) thus proved that "realism" and "cultural" factor are not the antithesis (Jorgensen, 2010, p. 86). Finally, now there are works by structuralists (Charles Glaser, Randall Schweller, and David Price) who focus not on states as major players, but on international organizations, arguing that they really matter and that they can minimize the security dilemma and the fear of deception that is inherent in every state (Glaser, 1995; Schweller \& Priess, 1997). At the same time, Jorgensen emphasizes that these all cases are isolated, and that neorealists, in general, do not pay systematic attention to the dimensions of social reality; they should supplement their keywords with concepts such as "morality", "ethics" and "identity" (Jorgensen, 2010, p. 86). 
So, in essence, defensive realists must go beyond the terms of structural realism to explain how states operate in the international system. They must combine internal and systemic theories to explain how this world works.

Offensive realists tend to rely exclusively on structural arguments to explain international politics, but they recognize that states sometimes act strategically unwisely and that these cases contradict their theories. But that is all that they agree with Waltz and other defensive realists.

Offensive realists believe that states should always look for opportunities to gain more power whenever it is possible. States must maximize power, so their ultimate goal must be hegemony. Offensive realists such as John Mearsheimer (2001) argue that possessing predominant influence is the best way to ensure one's survival. If for classical realists power is a goal in itself, then for structural realists power is a way to reach the goal- and the ultimate goal is survival. Power is based on the material capabilities of the state. The balance of power is a function of the tangible military equipment owned by states, such as armored divisions and nuclear weapons. However, states have another type of force, a latent force that belongs to the socio-economic components that are part of building military power. This is a latent government, which is based on the wealth of the state and population. Hidden power refers to the potential that can be used to compete with other states. It is clear from this discussion that war is not the only way for states to gain power. They can also do this by increasing their population and their share in the world's wealth.

This view is also easily confirmed in the BSR - both through the study of high-power policies and non-systemic actors such as China and Japan. These players are relatively new forces in the Black Sea area but have already shown remarkable success in redistributing power.

Offensive realists claim that balancing is often ineffective, especially when it comes to forming coalitions, and that this inefficiency provides some opportunities for a reasonable aggressor. In addition, states that are under threat sometimes prefer not to join a coalition; they try to force other states to assume the burden of testing a strong opponent while they themselves stand aside. Such behavior also creates opportunities for aggression. Offensive realists deny the claim that the defender has a significant advantage over the attacker. Indeed, historical data show that the party which initiates a war wins more often than it loses. Finally, although offensive realists acknowledge that sometimes conquest does not pay off, they also point out that sometimes it justifies itself. Conquerors can use the economy of a defeated state for profit, even in the information age. Peter Liberman claimed that information technology has an "Orwellian" dimension that contributes to repression (Liber- 
man, 1996, p. 126). Moreover, the victorious state does not need to occupy the defeated state in order to gain an advantage over it. The winner may annex part of the territory of the defeated state, divide it into two or more small states, or simply disarm and prevent rearmament. It seems then that this could almost be a direct statement on the peculiarities of Ukraine's policy as related to the fluctuations of "neutrality-NATO", "East-West", and its consequences, such as the loss of Crimea and the hybrid war.

All structural realists recognize that states can go to war for a number of reasons, so it is impossible to put forward a theory that will point to one factor as the major cause of the conflict. Security is not always the main driving force behind decision on war. Ideology or economic considerations sometimes matter more. For example, nationalism was the main reason why Bismarck started wars against Denmark, Austria, and France: he wanted to create united Germany.

It should be noted that after the Cold War, instead of the "end of history", we also encountered another source for the revival of nationalism as the leading ideology of the modern world with all its benefits (the consolidation of nations) and disadvantages (ethnic cleansing, disrespect for minority rights, the idea of expanding living space at the expense of "inferior peoples" - read as "failed states"). Maybe this therefore, from the realists, is the answer to the question, why - in an era of total informatization and of a growing influence of civil society on world politics - do states behave so irrationally in the XXI century?

Although, identifying the specific cause of wars/conflicts is not a fruitful approach, structural realists argue that their likelihood is influenced by the structure of the international system.

Some argue that the key variable is the number of great powers or poles in the system. Long-standing debates among realists are whether bipolarity is less prone to war than multipolarity, which is tempting to say in the $\mathrm{XX}$ century. However, this argument seems much less convincing when the timeline extends to the XIX century: from 1815 to 1853, and then from 1871 to 1914 there was no war between the great powers. The long periods of relative stability which have occurred in multipolar Europe compare favorably with the Cold War. Proponents of multipolarity also assert that great powers have more opportunities to fight each other in a multipolar system. In a multipolar system, there are three potentially conflicting dyads when there are three or even more great powers. Secondly, in a multipolar system, great powers are less hostile because the amount of attention they pay to each other is less than in a bipolar system. States cannot afford to worry too much about one of their neighbors; they must extend their attention to all great powers. With the end 
of the Cold War and the collapse of the Soviet Union, many realists argue that a monopoly has emerged (Wohlforth, 1999). In other words, the United States is the only great power- it has achieved global hegemony. Others, however, argue that the post-Cold War system is multipolar: the United States is, undoubtedly, the most powerful state on the Earth, but there are other major powers such as China and Russia (Mearsheimer, 2013, p. 85).

Instead of looking at the number of great powers to explain the phenomenon of war, some realists argue that the key variable is how much power each great power controls. Force can be more or less evenly distributed between large forces. Although the balance of power between all the great powers affects the prospects of all, the key is the relationship between the two most powerful countries in the system. Realists claim that the presence of a particularly powerful state promotes peace. However, war between smaller and larger powers is still possible because the balance of power between any two of them will sometimes be approximately equal, which suggests that one may defeat the other. But even if the dominant power believes that such wars can disrupt a favorable international order, it must be able to stop them or at least make them extraordinary (Mearsheimer, 2013, p. 86).

Some realists argue that it is wrong to focus on static indicators, such as the number of great powers or the amount of power that each has. They argue that instead, the focus should be on the dynamic of the balance of power, especially on the significant changes taking place in the distribution of power (Copeland, 2000). Perhaps their best-known argument is that an overwhelming force when opposing a rising enemy creates a particularly dangerous situation, as the result is usually a central war. The ruling state, knowing that its days at the top of power are numbered, has strong incentives to start a preventive war; the declining state must still operate over its rising competitor. Some scholars argue that an ascending state may also start a war (Mearsheimer, 2013, p. 87). But it does not make much sense, because time is on the side of the rising state; it does not need war to overtake the leading state.

This theoretical position can be fruitfully applied in the comparative analysis of the policy of the Russian Federation and the EU in the BSR: Russia acts as a predominant force that wants to restore hegemony over the former satellites and opposes the rising enemy ("collective West"). On the contrary, the EU does not need a war to expand its sphere of influence, which became important for the organization only after the last enlargement: the countries of the region, including Turkey, have chosen the path of integration into the European Union.

While examining the BSR, it is impossible to ignore Chris Brown's basic work on the policy of great powers (Brown, 2004), which proves that only 
in extreme cases can they "ignore" each other and cultivate a narrow, selfish, short-sighted concept of national interest, nor can the works of the eternal critic of the US foreign policy John Mearsheimer be ignored(Mearsheimer, 2003, 2006); likewise for one of the most fruitful works on the EU foreign policy by Barry Posen (Posen, 2004).

However, structural realist Jack Donnelly personally stressed that nowadays, rather than "Theories of International Politics", we need theories of international politics, both realistic and unrealistic, which together will give us a chance to come to terms with diverse human goals and complex practices and processes, that represent world politics (Donnelly, 2000, p. 198). Going further, we need to emphasize that we need to study not only material factors, but also ideological, social and cultural ones if we want to understand such "irrational" actors as Russia, China and even the EU.

\section{Constructivism}

The failure of leading researchers in prediction the imminent end of the Cold War on the basis of the dominant theories of IR increased the importance of new theoretical challenges, including the so-called "constructivist turn" (Checkel, 1998). Constructivists criticized the static material assumptions of traditional theory of international relations, emphasizing the social dimensions of IR and the possibility of changing them. The idea from which constructivism is based is that IR is a social construction. According to Nicholas Onuf, to construct something is to create a subject or object that would not otherwise exist. Material objects that do not exist in nature, but emerge through the acts of "human creation" (Onuf, 1989), have a certain meaning only in context. They are social constructions in so far as they are riddled with social values and norms. States, alliances or international institutions, namely collective subjects of international relations, are built on human nature, but take specific historical, cultural and political forms, which are the product of human interaction in the social world.

Perhaps the most ambitious constructivist work was Alexander Wendt's "Social Theory of International Politics" (Wendt, 1999). Jorgensen called it a "constructivist liberal theory of international cooperation" (Jorgensen, 2010, p. 67). As the title suggests, the book was an attempt to form an opposition to Kenneth Waltz's "Theory of International Politics", which had been published 20 years earlier. If in realism the main thing is material factors, then in constructivism there are social factors. If in realism the main thing is the "anarchy of the IR", then in constructivism, it is the possibility of creating an "anarchic community" based on attention to the identity of partners and the development of common norms. In other words, institutions transform interests, and interactions change both interests and identities. These considera- 
tions of Wendt were very close to the main provisions of the English school, for example, Tim Dunn's article "The Social Construction of the International Community" (1995) focuses on common norms, which are created by states themselves (Dunne, 1995); this allowed Chris Brown and Kirsten Ainley to call them "cousins of Theory of International Relations" (Brown \& Ainley, 2009 , p. 48). As for Wendt himself, he emphasized that although he considered himself as a part of the "loyal opposition", everything he sought was dialogue with Waltz's followers (Brown \& Ainley, 2009, p. 52).

Constructivists identified several topics. The first one is the concept of social construction which includes a difference in context, not in objective reality. Traditional theories of IR give priority to the identification of patterns. Constructivists sought to understand and explain extraordinary changes after the end of the Cold War by the importance of the historical context and asked whether it was possible to move from conflict to cooperation, from peace to war.

The BSR provides rich material to support this thesis, as the idea of cooperation between former enemies was at the heart of Turgut Ozal's arguments about the organization of the BSEC in 1990, before the collapse of the USSR; then there was the TRACECA program, the creation of the Parliamentary Assembly of the Black Sea Economic Cooperation (PABSEC), the Black Sea Trade and Development Bank (BSTDB), the Ituri project, and so on - successes and failures that cannot be explored without the context of the traditional ties of the Black Sea countries.

Secondly, constructivists emphasized the social dimensions of international relations and demonstrated the importance of norms, rules, and language (Fierke, 2013, p. 189). The importance of Gorbachev's "new thinking" for ending the Cold War, the growing importance of the concept of "humanitarian intervention" and the spread of liberal democratic values have provoked criticism of the realists` exclusive emphasis on material interests and power.

In fact, it is the trio of "norms, rules and language" that helps to explore the problems that remain unclear in the relations between the post-communist countries and their liberal-democratic partners in the BSR, based solely on the concept of competition for survival. In the case of Turkey, with its centralized and deeply personalized decision-making process (which became even more visible after the transition to a presidential form of government in 2017), as well as the diversity of cultural and civilizational identities in society, the constructivist approach reveals the specifics of foreign policy, rules and language. The Kurdish issue, the role of diasporas in Turkey, which support one side or another in "frozen" or hot conflicts in the region (Abkhazians, 
Ossetians, Circassians, Crimean Tatars, Meskhetian Turks, and Gagauzi) and significantly restrict the space for Ankara's ability to "maneuver" in the international arena - these things require a study of the impact of values on the formation of foreign policy.

Thirdly, constructivists claimed that international politics is far from being an objective reality, but is instead "the world of our creation" (Onuf, 1989). Constructivists introduced the possibility of agency (a person's ability to act, the ability to act as an independent agent, to make informed and free choices) and interaction. It is not that actors are completely free to choose their environment, but rather that they make choices in the process of interacting with others (Ruggie, 1998; Risse, 2000) and, as a result, create historical, cultural and political "realities". In this regard, IR is a social construct, and does not exist independently of human meaning and action. If IR is a construction, a game, then an important next step is to consider that the rules of the game can be changed (Onuf, 1989; Kratochwil, 1989). The central themes of changes, sociality and interaction point to the value of constructivism, an important step forward in the study of foreign policy compared to structuralist conclusions.

Most constructivists were critical of rationalism, but they did not reject it as a scientific method. The central issues of their dialogue with rationalists were the nature of being (ontology), the relationship between "structure agent", and the role of cognition.

Rationalist theories of IR have an individualistic ontology, because the fundamental unit of analysis is the individual (usually the state). For example, neorealist theory views states as if they are people trying to survive. In neoliberals such as Judith Goldstein and Robert Keohane ideas are cause-effect factors that fully formed actors exchange (Goldstein \& Keohane, 1993). Constructivists, on the other hand, emphasize social ontology. Being fundamentally social beings, states cannot be separated from the context that determines who they are and what opportunities they are given. Indeed, the concept of sovereignty is particularly a social category, as a precondition for recognizing the sovereignty of individual states is a common understanding and acceptance of this concept. John Searle went so far to argue that social facts depend on human consent and require human institutions; another example is that the boundaries that divide states exist only by human consent (Searle, 1995, p. 2).

The "agent - structure" relationship is important for both rationalism and constructivism, but is perceived differently by each of them. For rationalists, the structure functions through competition and the distribution of material opportunities. Rationalists are guided by the logic of consequences, namely, a rational action is one that will produce a result that maximizes the 
interest of the individual. Constructivists are guided by the logic of conformity (March \& Olson, 1989), i.e. a rational act is a legitimate act determined not by purely individual interests, but by common values and norms in institutions or other social structures. Actors try to "do the right thing" rather than optimize their preferences (Risse, 2000, p. 4). Human rights are an integral feature of liberal democracies, and at the international level an integral feature of their legitimacy. The social structure leaves more room for agency the influence of the state on the surroundings and vice versa.

The title of Alexander Wendt's famous article "Anarchy Is What States Make of It" (1992) is the best expression of this idea. Although constructivism was firstly introduced in IR by Nicholas Onuf (1989), its foundations are often identified with this article by A. Wendt. In the article, he discussed the potential of the agency in the absence of global power in anarchic conditions. Wendt's criticism directly concerned the assertion that states had little choice but to compete to survive. Wendt provided a basis for thinking about interests as "constructed" and thus transformable. He aimed to build a bridge between two traditions, rationalist and reflective (or positivist and postpositivist), and developed constructivist arguments borrowed from sociology. Wendt believed that actors "determine their interests by determining the situation". Institutions are relatively static sets/"structures" of identities and interests, but have a motivating force only due to the socialization of the actor. It is necessary to take into account the "intersubjective structure of identities and interests in the system" and to interact - not to act individually. Wendt argued that actors have the ability to choose. This can happen, for example, in the presence of new social circumstances that cannot be reflected in the old concepts. Actors can participate in "self-reflection and practices specifically designed to transform their identities and interests", and "change the games" of which they are a part. Interactions develop over time and are not always characterized by hostility and selfishness (Wendt, 1992, pp. 404-405).

American foreign policy cannot be explained without taking into account the variable "identity". John Ruggie compared US policy toward Canada, France, on the one hand, and Egypt and China, on the other. He ensured that it was not just due to security, but to a common identity with the former and a dramatically different one with the latter. Ruggie also stressed that "interests" were not an invariable category; they were subject to constant change under the influence of interaction with "others" (Brown \& Ainley, 2009, p. $50)$.

The United States and the United Kingdom have been evolving as friends for a long time. Many countries in the modern EU are former enemies who learned to cooperate with each other. Although constructivists do 
not deny the importance of interests, they associate them with the "identity" of the actor. Neither identity nor interests can be detached from the world of social significance. The identity of liberal democracies cannot be separated from the interest of human rights. In a region like the BSR, where liberal and illiberal actors interact, with illiberal ones predominating, this adds difficulties to a process of any sectoral cooperation.

When thinking about cognition, many realists and constructivists relied on Max Weber's concept of 'Verstehen' (understanding). The difference is that the former emphasized the individual and the latter emphasized the social. However, the difference is not so significant; the rational thought processes "Alter" and "Ego" (Wendt, 1992) precede social interaction. Thus, constructivism adds a social dimension that rationalists lacked. Constructivism borrows from positivists "causality" and "hypothesis" and complements it with "rationality of individuals built-in the social context".

According to Brown and Ainley, "constructivism has become a label, which began to try on scientists, especially in the United States, who wanted to gain some independence from the mainstream American Theory of International Relations, and at the same time maintain a certain level of respectability" (Brown \& Ainley, 2009, p. 48). In doing so, they identified themselves with the middle ground between the rationalist and poststructuralist approaches. Brown and Ainley, however, believe that the works of A. Wendt, F. Kratochvil, and N. Onuf are radical alternatives to the conventional Theory of International Relations (Brown \& Ainley, 2009, p. 48). Is that really so?

Both rationalists and constructivists argue that they are not divided by great differences (Wendt, 1998, p. 116; Katzenstein, Keohane \& Krasner, 1998, p. 675). In the last two decades, IR specialists have been trying to build a dialogue between classical realism and constructivism (Sterling-Folker, 2002; Barkin, 2003; Jackson, 2004). Realism makes assumptions about actors and how they act (seekers of power that exist in a competitive environment). From a constructivist point of view, it is necessary to analyze how competitive relations turn into processes of interaction.

The role of language is largely ignored in discussions between rationalists and constructivists. Between looking at language as a "mirror of the objective world" or as a "pure interpretation" is an understanding of language and action as a "rule-based norm". From the point of view of constructivists, the use of language is fundamentally social. We socialize and understand how to act in the world: what it means to promise, to threaten, to lie; which it means to vote, to deploy a missile system. The use of language is a part of the action in the world. Without language, we would not be able to give meaning to objects or actions, to think or express feelings. Attitude towards language 
as a norm requires us to look at what language is used by social actors (Fierke, 2013, p. 196).

For example, the dominant categories that defined identity in communist Yugoslavia differed from those that arose with the conflict between Serbs, Croats, and Muslims. The category "Yugoslavia" covered everyone under the label "South Slavs". However, ethnic categories became the norm during the transition of the conflict in Yugoslavia. Although SFRY is the clearest example, similar circumstances can be found in the BSR.

Intentions and actions are determined by the public language of socially formed actors. The "intentions" of those involved in ethnic cleansing cannot be separated from the social world, in which neighbors have become "dangerous strangers" defined as Chetniks, Ustaše or the Ottomans - labels with a deep historical resonance - which must be eliminated as a threat. We cannot get inside the individual consciousness, and the competition for the "true" cause or intention usually turns into a battle of interpretations. Questions should be asked, focusing on the social context of the action under study and how it became possible (Fierke, 2013, p. 197).

We can ask the question, "how did this become possible", as Peter Howard (2004) put it: that Iraq was in fact a lesser threat to the United States than North Korea, but still became the target of invasion. He traced how the historical pattern of interaction with the United States laid the groundwork for different policies toward the two "axes of evil". The question "how is this possible" reveals the importance of public language. Now it is known that intelligence agencies on both sides of the Atlantic were mistaken in believing that Iraq had weapons of mass destruction. Whether the actors believed intelligence or forged them, this "ground" made the invasion possible. This method of convincing the American public and American soldiers that this is was a legitimate act of government proved effective. The legitimacy of the base arguments was strengthened by the political discourse between Saddam Hussein and the 9/11 attacks. The assumption that Hussein had weapons of mass destruction, although based on erroneous data, created a context to justify the invasion. The reason for the invasion was articulated in common political language. The intention to invade was laid down in language games and in the very act of invasion. Thus, there has been a turn in IR to treat invasion as an international "practice" or a socially significant model of action which is more or less competently implemented (Adler \& Pouliot, 2011).

\section{Conclusions}

In the 1990s, it was common for scholars to declare that international politics had transformed with the end of the Cold War, that the world was becoming more peaceful and realism was dead. Economic globalization has 
supposedly bound the state; some even foresaw her imminent death. Others argued that Western elites were thinking for the first time about international politics in terms of cooperation and the hope that the globalization of knowledge would contribute to the spread of this new approach. Many have argued that democracy is spreading around the globe, and because democracies do not fight each other, we have reached, according to Fukuyama, the "end of history". Others argued that international institutions were finally able to motivate key actors to act in accordance with the rule of law.

After 11 September, this optimism faded or even disappeared completely, and realism returned. This was partly due to the fact that almost every realist opposed the war in Iraq, which turned into a strategic catastrophe for the United States. But more to the point, there is no reason to believe that globalization or international institutions have harmed the state. Indeed, the state, as the main international actor, has a bright future, not at least because of the nationalism, that supports the role of the state, remains a powerful political ideology. Even in Western Europe, where unprecedented economic integration has taken place, the state lives and prospers. In addition, military power remains an essential element of world politics. The United States and the United Kingdom, two major liberal democracies, have fought five wars since the end of the Cold War. Iran and North Korea remind us that nuclear proliferation remains a serious problem, and it is easy to formulate plausible scenarios where India and Pakistan find themselves at war with nuclear weapons. It is also possible, though unlikely, that China and the United States could be drawn into a war (over Taiwan or North Korea). As for China's rise, even optimists acknowledge that there is a serious problem with this profound shift in world power. In essence, the world remains a dangerous place, although the level of threat varies from place to place and from time to time. States are worried about their survival, which means that they cannot ignore the balance of power. International politics remains synonymous with power politics, as it was before.

Therefore, scholars should proceed from the concept of power and develop their own answers as to why states want power, how much power is enough, and when competition in security can lead to an armed conflict. Reflections on this are needed to develop strategies on how states can mitigate the dangers of international anarchy.

But it is also true that "the War on Terror" after 9/11 not only revived political realism, but also gave obvious themes of "constructivist turn", such as identities and human emotions, greater social value expressed in political narratives. President George W. Bush had to give good reasons for his foreign policy actions as do all modern politicians. Although language and practice 
interact, they also contain contradictions that contribute to the transformation of the context. These inconsistencies manifested themselves in several aspects of the Bush administration's policies. Firstly, the practice of war involved human rights abuses, contempt for international law, and ignorance of the voices of even traditional allies who opposed the invasion of Iraq. Secondly, measures to suspend many civil liberties during the war were in conflict with the purpose for which the war was being waged, namely to preserve a way of life defined by openness and freedom. While the United States initially received broad support and sympathy from the international community after the 9/11 attacks, that support weakened over time as Bush`s practices violated the rules and norms of international law. The dubious legitimacy of the 2003 invasion of Iraq, the Guantanamo incidents, and the exposure of photographs of prisoners humiliated in Abu Ghraib in Iraq have all led to a serious loss of legitimacy and questions about whether the United States has deviated from its basic principles in trying to overcome a security threat. Although these practices seemed to violate international norms and rules, this violation soon strengthened the importance of norms and rules for determining proper conduct in IR.

As constructivist analysis has shown, human suffering is often used to consolidate collective identity and mobilize military force. In this regard, this particular constructivist analysis that opens up space for greater reflection on both sides of the conflict, allowing actors to step back and ask how their own actions can help to build the same problems they sought to solve.

Thus, when analyzing specific cases, it becomes clear that joint research by realists and constructivists gives a much more objective picture of reality than they are able to do alone.

\section{References}

1. Adler, E., \& Pouliot, V. (Eds.). (2011). International Practices. Cambridge: Cambridge University Press.

2. Barkin, S. (2003). Realist Constructivism. International Studies Review, 5, 325-342.

3. Brown, C., \& Ainley, K. (2009). Understanding International Relations. Palgrave Macmillan.

4. Brown, C. (2004). Do Great Powers Have Great Responsibilities? Great Powers and Moral Agency. Global Society, 18, 21-42.

5. Brown, M. E., Coté Jr, O. R., Lynn-Jones, S. M., \& Miller, S. E. (2004) (Eds.). Offense, Defense, and War. Cambridge: MIT Press.

6. Buzan, B. (1993). From International System to International Society: Structural Realism and Regime Theory Meet the English School. International Organization, 47, 3, 327-352. 
7. Checkel, J. T. (1998). The Constructivist Turn in International Relations Theory. World Politics, 50, 2, 324-348.

8. Copeland, D. C. (2000). The Origins of Major War. Ithaca, NY: Cornell University Press.

9. Dickinson, G. L. (2008). The European Anarchy. Gloucester: Dodo Press.

10. Donelly, J. (2000). Realism and International Relations. Cambridge: Cambridge Univ. Press.

11. Dunne, T. (1995). The Social Construction of International Society. European Journal of International Relations, 1, 367-389.

12. Dunne, T., \& Schmidt, B. (2004). Realism. In Baylis, J., \& Smith, S. (Eds). The Globalization of World Politics, 99-112. Oxford: Oxford University Press.

13. Elman, C. (1996). Horses for Courses: Why Not a Neorealist Theory of Foreign Policy? Security Studies, 6, 7-53.

14. Fearon, D. (1998). Domestic Politics, Foreign Policy, and Theories of International Relations. Annual Reviews of Political Science, I, 289-313.

15. Fierke, K. M. (2013). Constructivism. In Dunne, T., Kurki, M., Smith, S. (Eds.). International Relations Theories. Discipline and Diversity, 187-204. Oxford Univ. Press.

16. Glaser, C. L. (2010). Rational Theory of International Politics: The Logic of Competition and Cooperation. Princeton: Princeton University Press.

17. Goldstein, J., \& Keohane, R. O. (Eds.) (1993). Ideas and Foreign Policy: Beliefs, Institutions, and Political Change. Ithaca, NY: Cornell University Press.

18. Howard, P. (2004). Why Not Invade Korea? Threats, Language Games and US Foreign Policy. International Studies Quarterly, 48/4, 805-828.

19. Huntington, S. (1996). The Clash of Civilizations and the Remaking of World Order. NY: Simon \& Schuster.

20. Jackson, P. T. (Ed.) (2004). Bridging the Gap: Toward a Realist-Constructivist Dialogue. International Studies Review, 6/2, 337-352.

21. Jorgensen, K. E. (2010). International Relations Theories. A New Introduction. Palgrave Macmillan.

22. Katzenstein, P., Keohane, R. O., \& Krasner, S. D. (1998). International Organization and the Study of World Politics. International Organization, 52/4, 645-685.

23. Kratochwil, F. (1989). Rules, Norms and Decisions: On the Conditions of Practical and Legal Reasoning in International Relations and Domestic Affairs. Cambridge: Cambridge University Press.

24. Liberman, P. (1996). Does Conquest Pay: The Exploitation of the Occupied Industrial Societies? Princeton: Princeton University Press.

25. March, J. G., \& Olson, J. P. (1989). Rediscovering Institutions. New York: Free Press.

26. Mearsheimer, J. J. (2001). The Tragedy of Great Power Politics. New York: Norton.

27. Mearsheimer, J. J., \& Walt, S. (2003). An Unnecessary War. Foreign Policy, $134,50-59$.

28. Mearsheimer, J. J. (2006). Conversations in International Relations, Part I and II. International Relations, 20, 105-125 / 231-245. 
29. Mearsheimer, J. J. (2013). Structural Realism. In Dunne, T., Kurki M., Smith S. (Eds.). International Relations Theories. Discipline and Diversity, 77-93. Oxford Univ. Press.

30. Nau, H. R. (2002). At Home Abroad: Identity and Power in American Foreign Policy. Ithaca, L.: Cornell Univ. Press.

31. Onuf, N. (1989). World of Our Making: Rules and Rule in Social Theory and International Relations. Columbia: University of South Carolina Press.

32. Posen, B. R. (1984). The Sources of Military Doctrine. Ithaca, NY: Cornell University Press.

33. Risse, T. (2000). "Let's Argue!": Communicative Action in World Politics. International Organization, 54/1, 1-39.

34. Ruggie, J. G. (1998). What Makes the World Hang Together? Neo-Utilitarianism and the Social Constructivist Challenge. International Organization, $52 / 4,855-885$.

35. Schmidt, B. C. (1988). The Political Discourse of Anarchy. Albany: State University of New York Press.

36. Schweller, R., \& Priess, D. (1997). A Tale of Two Realisms: Expanding the Institutions Debate. Mershon International Studies Review, 41, 1-32.

37. Searle, J. R. (1995). The Construction of Social Reality. London: Allen Lane; New York: Free Press.

38. Snyder, J. (1991). Myths of Empire: Domestic Politics and the International Ambition. Ithaca, NY: Cornell University Press.

39. Snyder, G. H. (1997). Alliance Politics. Ithaca, NY: Cornell Univ. Press.

40. Sterling-Folker, J. (2000). Competing Paradigms or Birds of a Feather? Constructivism and Neoliberalism Institutionalism Compared. International Studies Quarterly, 44/1, 97-119.

41. Van Evera, S. (1999). Causes of War: Power and the Roots of Conflict. Ithaca, NY: Cornell University Press.

42. Walt, S. M. (1987). The Origins of Alliances. Ithaca, NY: Cornell University Press).

43. Waltz, K. N. (1979). Theory of International Politics. Reading: Addison-Wesley.

44. Waltz, K. N. (2001). Man, the State, and War: A Theoretical Analysis. Columbia: Columbia University Press.

45. Wendt, A. (1992). Anarchy is What States Make of It: The Social Construction of Power Politics. International Organization, 46/2, 391-425.

46. Wendt, A. (1998). Constitution and Causation in International Relations. Review of International Studies, 24/5, 101-117.

47. Wendt, A. (1999). Social Theory of International Politics. Cambridge \& New York: Cambridge University Press.

48. Wohlforth, W. C. (1999). The Stability of a Unipolar World. International Security, 24/1, 5-41. 


\section{CHAPTER 2}

\section{TURKEY'S POLICY IN THE BLACK SEA REGION: THE BALANCE OF POWERS, THREATS AND INTERESTS}

(Yevgeniya Gaber)

\section{Introduction}

Turkey holds a unique position in the Black Sea region. Being a NATO member with the second largest armed forces in the Alliance, it continues to develop close defence, political and military cooperation with the Russian Federation. Major regional actor in the Black Sea, Ankara has vital interests in the security sphere in the Middle East, implements ambitious economic and energy projects in the Eastern Mediterranean, benefits from the common historical and cultural heritage spreading its "soft" power in the Caucasus and Central Asia.

On the one hand, this multiregional identity provides Turkey with additional leverages of influence on a vast geography from the Balkans to the Western China. On the other, Turkey's unique position does not only entail geopolitical advantages but also creates difficult security dilemmas, which place significant constraints on Ankara's foreign, security and even domestic policies.

The Black Sea basin has remained an area of continuous confrontation between the regional powers since the times of the Russo-Ottoman wars. Though an area of contested leadership, the Black Sea, often referred to as the "Russian-Turkish lake", has been regarded in both capitals as a sphere of exclusive national interests, and none of the countries was ever willing to let the "outsiders" meddle in the regional affairs.

During the Cold War, Turkey once again found itself on the different sides of the "iron curtain" with Russia, playing a role of an important NATO ally whose primary mission was to deter the Soviets at the South-Eastern flank. At the same time, Ankara's relations with the United States were developing more under pressure of the structural incentives of the bipolar international system rather than as a result of a "free will" and well-balanced choice (In this regard, the Cyprus crisis of 1974 and the subsequent US embargo on arms sales to Turkey, which almost led to severance of diplomatic ties, is a good example of a real level of trust and coordination between the two allies).

In the 1990's, Ankara tried to move away from a traditional NATO-Russia dichotomy in its foreign policy by claiming its own leadership ambitions, promoting multilateral initiatives in the region and developing bilateral relations with the new independent states that emerged after the collapse of 
the USSR. It was then, that the Friendship and Cooperation Agreement was signed between Ukraine and Turkey in 1992, laying the foundations of the modern bilateral relations.

The first years in the aftermath of the Cold War were marked with a number of multilateral integrational projects as an emerging track in Turkey's regional policy. The biggest of them, the Black Sea Economic Cooperation Organization (BSEC), was founded in 1992 with the headquarters in Istanbul. However, quite soon it became evident that such formats were not able to provide neither a regional stability nor a national security. Thus, the next years witnessed an enhanced regional cooperation between Turkey and the West (mostly, US and NATO). For instance, when NATO's Partnership for Peace program was launched in 1994, Turkey (a NATO member since 1952) used this opportunity as a chance to develop close relationships with the post-Soviet republics, well aware of the fact that its cooperation with Washington would bring significant dividends in maintaining relations with the new independent states and, thus, strengthen Turkey's regional stance without going at odds with Russia.

This chapter will focus on the analysis of Turkey's modern policy in the Black Sea region through the prism of structural realism and constructivism theories. It will start with a short overview of historical preconditions shaping Turkey's strategic culture, then look at the recent developments in its regional policy and conclude with three possible scenarios of changing Ankara's regional stance in the mid-term future.

\section{Theoretical framework of Turkey's regional policy analysis}

Structural realists see the main way of sustaining equilibrium in the international system in maintaining the balance of power, but mainly regard it as a function of the constraints and incentives, which the structure imposes on its elements. According to Kenneth Waltz, one of the original founders of the neorealist school of thought, the balance of power logic plays a defining role in alliance formation since the anarchy of the international environment forces the states to balance against the most powerful one. The structural changes and shifts in the existing balance of power can happen any time but any changes in the configuration of the military forces or political power rest unable to change a basic structure of the world system or drastically modify the behaviour of its sovereign parts. In his own words, this does not mean that the balance of power once achieved will be preserved, but that the balance of power once disturbed will tend to be restored (Waltz, 1979).

Elaborating the Waltz's theory, another neorealist Stephen Walt came up with an idea of the balance of threat, shifting the focus of analysis from the level of existing distribution of power to the level of potential threats. 
He, thus, argued that since survival was the highest end, states would not take chances and risk further strengthening the hand of rising or threatening powers. Walt also stressed that "because an alignment that preserves most of a state's freedom of action is preferable to accepting subordination under a potential hegemon... it is safer to balance against potential threats than to hope that strong states will remain benevolent" (Walt, 1985, p. 15).

This theory can explain, for instance, why Turkish leadership has preferred to balance against the American power rather than to align with it, having with almost $80 \%$ of the population who see the US as a major threat to their national security (Turkish Foreign Policy, 2019).

Contributing to the neorealist debate, Glenn Snyder defended the idea that even under the "bipolar global system" the behaviour of states should be regarded within "multipolar regional subsystems", existing as its autonomous parts (Snyder, 1997, p. 266). Balancing in the post-bipolar world has become even more clearly "regional in its character". As Stephen Brooks and William Wohlforth put it, "Politics, even international politics, is local. Although American power attracts a lot of attention globally, states are usually more concerned with their own neighbourhoods than with the global equilibrium. Were any of the potential challengers to make a serious run at the United States, regional balancing efforts would almost certainly help contain them..." (Brooks \& Wohlforth, 2002, p. 24).

Besides, balancing against a global power entails significant costs, making it an available option only to a limited number of actors. For this reason, many secondary states lacking resources and leverages of influence to pursue a classical balancing on the global level choose a strategy of "regional balancing" trying to maintain equilibrium at least in their close neighbourhood. For the most part, such models of behaviour are typical for the foreign policy of those states which cannot question the US dominance in the global politics but have enough power to counterbalance their influence in certain regions. Consequently, this policy often leads to a clash of interests between these secondary states seeking regional leadership with those of the United States as well as with the NATO commitments.

While some countries try to balance against the dominant partner, others choose to engage in various forms of bandwagoning with it in order to increase gains from this cooperation, or to reduce possible threats from a hostile environment. Taking into account military, political, diplomatic and other benefits that allying with a global leader can bring to a second-tier state, as well as the costs of counterbalancing against it, it might be more reasonable for many regional states to align with the United States, rather than against it (Huntington, 1999, p. 45-46). 
Similar considerations were also expressed by Randall Schweller, who proposed his concept of balance of interests, a revision of Kenneth Waltz's balance of power and Stephen Walt's balance of threat theories. Assuming that states will try to unite their efforts on the principle of common interests in order to effectively oppose other countries with divergent interests, he explained the desire of many second-tier powers to align with the superpower in order to ensure their own goals at the expense of a leader of the international system (Schweller, 1994).

Christopher Layne put forward his explanation of a motivation behind bandwagoning with a global leader. As he correctly observes, this happens "because counterbalancing against an actual hegemon is much more complex than balancing against a rising one" or allying with it (Layne, 2006, p. 29). William Wohlforth also underlined that formation of "counterhegemonic alliances" demanded much more efforts than formation of any other state coalitions, because there is always a temptation to benefit from the advantages which naturally come from an alliance with a more powerful state: "states are tempted to free ride, pass the back, or bandwagon in search of favours from the aspiring hegemon" (Wohlforth, 1999, p. 29).

As John Mearsheimer put it, in fact, the only choice facing states in the realists' world is between balancing against a more powerful state at their own expense or allying with it and passing the buck. This brings him to a conclusion that most countries will prefer the second option every time they face a real threat to their interests or national security (Mearsheimer, 2001, p. 140). Another political scientist Jack Snyder shared similar views (Snyder, 1990).

On the same issue, William Wohlforth commented that the apparently dominant position of the United States in the post-Cold War era has incentivized other states to unite around the US as the only center of power in the new system: "the second-tier states faced incentives to bandwagon with the unipolar power as long as the expected costs of balancing remained prohibitive" (Wohlforth, 1999, p. 8).

Therefore, various concepts of the neorealist school of international relations can be collected under two major headlines: 1) those based on the principle of "balancing against" a more powerful state ("balance of power", "balance of threat", "balance of interests"); and 2) those based on the idea of "bandwagoning" or allying with a stronger state.

According to this logic, the authors of the abovementioned concepts propose the second-tier, regional states two fundamentally different styles of behaviour on the international arena. Proponents of the concept of "bandwagoning with a global leader" expect that all secondary states will join the apparent leader of the system to maximize their profits, de facto meaning 
uniting around the United States in the post-Cold War era. Whereas advocates of the "balancing" concepts argue that regional states will continue their attempts to create coalitions in order to counterbalance the influence of the global power at least on the regional level ("regional balancing").

Although there is an ongoing debate between these two "camps", the case of Turkey has proved that both strategies can be successfully combined in the foreign policy-making of one state. An overview of Ankara's security and foreign policy strategy in the aftermath of the Cold War can be summarized in a phrase coined by Daniel Whiteneck: a "long-term bandwagoning and short-term balancing" against the United States in order to maximize gains and minimize possible threats (Whiteneck, 2001).

Thus, on the global level Turkey acts as a long-term strategic partner of Washington, participating in global anti-terrorist coalitions, cooperating within multilateral NATO framework and bilateral agreements, since, like most other countries in the world, it lacks both military and diplomatic resources to oppose the United States. However, at the regional level, where the US does not have sufficient leverages to act unilaterally without the support of its partners on the ground (and where Ankara's national interests demand closer cooperation with other regional actors), Turkey often choses to free-ride claiming its rights for a self-sufficient autonomous foreign policy. Hence, this quest for "strategic autonomy" and ambitious regional initiatives addresses "regional problems with regional powers".

As Joshua Walker put it, although "Turkey's long-term interests in the region and beyond align with those of the United States", Ankara continues to work on developing closer cooperation with the regional actors, successfully maintaining this "fragile balance" between these two vectors of its foreign policy (Walker, 2008, p. 106).

The theory of neorealism, or structural realism, explains well the systemic incentives and constraints, which determine the objective conditions shaping Turkish foreign policy in the Black Sea region. Obviously, after the end of the Cold War, the level of systemic tensions has become much lower, the impact of structural constraints on the foreign policy-making of regional states weakened, giving Ankara much more opportunities to pursue diverse, multi-vector and more independent regional policy, often at the expense of the US interests. According to the neorealist logic, in these new geopolitical realities the main incentive of Turkey, like of any other regional state, becomes a desire to counterbalance against US as a leader of the global system by joining forces with other second-tier states in the regional subsystem (primarily with Russia). On the other hand, bandwagoning with US and cooperating on the matters of common concern largely benefited Ankara in promoting its own interests in the region. 
With this being said, it would be a significant simplification to consider Turkey's actions in the Black Sea exclusively through the lenses of neorealism, which leaves out many factors not related to the structure of the international system. Although states and alliances are indeed guided by the systemic logic (actually doing what the current structure of the world system "allows" them to do), their policies take concrete forms as a result of subjective decisions of state leaders and the interplay of many historical, social, religious, cultural and ideological factors.

In particular, one of the important issues explored by constructivism is the impact of a historical trauma and nation's collective memory on the formation of its strategic culture. As Douglas Becker wrote in his article "Memory and Trauma as Elements of Identity in Foreign Policy Making", the Waltzian neo-realist approach to foreign policy formation is guided by "systemic-level variables", such as the number of poles, whereas "power distributions and structures determine interests and opportunities". By contrast, "constructivists highlight the importance of identity and image in guiding state foreign policy behaviour". It is, thus, a combination of both that allow for a comprehensive study of a state's foreign policy choices (Becker, 2014, p. 57).

Another constructivist Ted Hopf also emphasized the importance of a multi-level analysis: "whereas neorealism assumes that all units in global politics have only one meaningful identity, that of self-interested states, constructivism treats identity as empirical question to be theorized within a historical context" (Hopf, 1998, p. 178).

In the case of Turkey, with its centralized and highly personalized decision-making process, diversity of cultural and civilizational identities, and a complex historical heritage, constructivist approach allows to fill these methodological gaps of a systemic-level analysis.

\section{Historical Roots of Turkey's Black Sea Policy}

Turkey's strategic thinking regarding the Black Sea region has been shaped by two major historical traumas.

Firstly, the Russo-Ottoman wars of the $18^{\text {th }}-19^{\text {th }}$ centuries, which proved Russian dominance in the region. They also created a myth of "great Russia", whose interests "have to be taken into account" in this part of the world and whose overwhelming power "does not allow the luxury of not cooperating with Russia" for any regional country.

Secondly, the so-called "Sèvres syndrome" meaning Turkey's deeply rooted distrust to the Western countries, which is embedded in collective memory as a threat of "being betrayed and weakened by the West" (the Sèvres Syndrome is a popular belief in Turkey that some outside forces, especially the Western countries, have a hidden agenda to weaken or divide the coun- 
try. The term originates from the 1920 Treaty of Sèvres, which was signed after the WWI between the Ottoman Empire and the Allied Powers. The Treaty marked the partitioning of the Ottoman Empire and led to the occupation of considerable territories by Britain, France, Italy, and Greece). This lack of trust is still defining political rhetoric of the nationalist and conservative parties, including those in the government coalition. In many cases, these sentiments are reinforced with strong anti-American, anti-Western and nationalist feelings dominating in Turkish society or find support in Kremlin-instigated Eurasianism concepts. Advocates of a closer cooperation with Russia have reportedly gained more bureaucratic influence as they have assumed some positions in the Turkish foreign ministry and armed forces vacated by "Atlanticists" in the wake of the 2016 coup attempt (Flanagan \& Larrabee, 2020, c. xix).

This psychological and geopolitical trap of being stuck between the two major powers, resulted in Turkey regarding the Black Sea as either a "Russian lake" or a "NATO's backyard". As a result, multilateral regional diplomacy became instrumental to reaching Ankara's goals of a status-quo stability and regional leadership.

The Balance of Powers: between the "Russian Lake" and "NATO's Backyard"

In the aftermath of the Cold War and the dissolution of the Soviet Union Turkey's interests in the Black Sea region were determined by the necessity to deter emerging Russia's influence as well as by its own arising leadership ambitions.

To achieve both goals, Ankara has become the main driving force behind the regional integration processes since early 1990's, when it initiated the first regional organization based on ideas of economic cooperation. Extending the "Black Sea area" to include six littoral states, and Moldova, Armenia, Azerbaijan, Greece, Albania (and later - Serbia), the Black Sea Economic Cooperation (BSEC) initiative emerged in 1992 giving a rare opportunity to bring twelve countries under the umbrella of the Ankara-led multilateral regional organization. By bringing together countries from different geographies - from the Caucasus to the Balkans - Turkey prioritized a more inclusive approach, which allowed it to claim a leading role in a much broader and complex regional architecture.

Many experts believe that "such grouping of those states clearly indicates the absence of a conception of the Black Sea region, as a single entity of littoral states, in Turkey's foreign policy thinking and strategic planning" (Petriashvili, 2015). To quote D. Lynch, every time "when the focus of the regional heavyweights, such as Russia and Turkey, has been toward the re- 
gion, their objective has been traditionally how this region could potentially become part of their respective spheres of influence" (Lynch, 2003, p. 10) rather than how to create a strong sense of regionalism or to promote the spirit of regional cooperation.

Hence, BSEC has become the first step on the way to mapping an autonomous regional system under the Turkey's leadership. This helped Turkey reach its goals. On the one hand, being a NATO member and long-term US ally, Ankara has got important leverages to counterbalance Russia's growing influence in the region. On the other, the "regional solutions for regional problems" approach, adopted by Turkey and gladly welcomed by Moscow, was called to prevent the militarization and "internationalization" of the Black Sea basin in case of a wider presence of the NATO navy or military bases in the region.

Historically, one of the major concerns for Turkey has been to prevent the Black Sea from becoming "a new focal point of global rivalry and conflict", and in this regard any extension of naval power beyond the existing measures has been regarded by Ankara as a dangerous move to change the status quo and, thus, destabilize the so far "neutral" region (Celikpala, 2010, p. 289).

Turkish experts acknowledge that "Turkey's position in the Black Sea is based on defending the status quo, and the country opposes interference by outside powers, creating a de facto Turko-Russian condominium in the Black Sea. Very strict adherence to the Montreux Convention of 1936, which regulates the passage of naval warships from the Mediterranean to the Black Sea via the Turkish Straits, forms the basis of Turkish policy" (Devlen, 2014, p. 2).

That is why, for instance, in 2006 Turkey and Russia opposed the extension of NATO's Operation Active Endeavour from the Mediterranean to the Black Sea. Both countries considered a more active US involvement as a destabilizing factor in the region. Officially, Turkey claimed that the presence of NATO warships in the Black Sea might threaten Article 18 of the Montreux Convention, which put restrictions on the number, type and length of stay of non-littoral states' warships in the "Straits". Besides, Turkish officials argued that NATO was already active in the Black Sea through the presence of the Turkish, Bulgarian and Romanian navies (Winrow, 2007, p. 130-131). However, this raised accusation in the West that Turkey and Russia were striving to establish a "naval condominium" in the Black Sea (Socor, 2005).

From Turkey's point of view, NATO's Operation Active Endeavour would be redundant to the Black Sea Harmony, a Turkish national operation to patrol the Black Sea basin, which was later expanded to littoral states, and 
to BLACKSEAFOR, another regional initiative led by Turkey. As Turkish TEPAV analyst S. Koru said, "with most of these initiatives, Turkey was careful to work with regional countries only... [since] Ankara wanted to create an institutional framework that would facilitate its leadership in the region. Initiatives by its Western allies would not only undermine the regional legitimacy of this kind of diplomacy, but also overshadow Turkey's role" (Koru, 2017).

The tendency to keep outsiders off the region became even more evident during the Russo-Georgian war of 2008, when Ankara denied passage for two American vessels carrying humanitarian aid to Georgia, in a fear of provoking Russia's response and further militarization of the Black Sea. Officially, the reason to deny passage was a violation of the Montreux Convention, but the fear of a negative reaction from Russia seemed a similarly reasonable justification.

At the same time, Turkey's then-Prime Minister Recep Erdogan proposed the idea of creating the "Caucasus Stability and Cooperation Platform", a regional organization bringing together five regional states (Turkey, Russia, Armenia, Georgia and Azerbaijan) to work on the settlement of the conflict. Turkish then-Foreign Minister Ali Babacan explained it by saying that these "countries need to develop a functional method of finding solutions to their problems from within", instead of waiting for help to come from outside (Babacan, 2008).

Since 2008, Turkey's regional policy has been defined to a considerable extent by this concept of creating "regional solutions for regional problems", contributing to Ankara's image of an independent security actor playing a leading role in regional processes while minimizing the military and even at times the diplomatic presence of its traditional Western partners. Washington, well aware of Turkey's concerns about losing its dominant position in the Black Sea basin to the growing US presence, has actively supported trilateral formats of Bulgaria - Romania - Turkey military exchanges and consultations, in an effort to assuage Ankara's fears of violation of the Montreux Convention (Cohen \& Conway, 2006).

However, when in 2016 Romanian president came up with a so-called "Black Sea flotilla" initiative, which was supposed to include Romanian, Bulgarian, Turkish and Ukrainian navies in order to develop interoperability among the staff and conduct joint naval exercises, the idea was criticized by Ankara for bringing unnecessary tensions to the region, provoking further escalation with Russia and replicating the already existing NATO formats of naval cooperation (Tol, 2019).

It should be mentioned that the idea got initial support from Ankara during the 2015-2016 "jet crisis" with Russia, when President Erdogan re- 
versed his traditional reluctance about a NATO presence in the Black Sea, acknowledging that NATO was "absent from the Black Sea": "The Black Sea has almost become a Russian lake. If we don't act now, history will not forgive us" (Flanagan, 2020, p. 126). So, when NATO allies agreed at the 2016 Warsaw Summit to initiate a tailored forward presence for the Black Sea region, Ankara pledged to participate in Romania's multinational brigade under a NATO flag, aimed at responding to Russia's assertive posture in the region. However, as the crisis with Russia was soothed and relations with Moscow quickly improved after the failed coup attempt, Turkey "dragged its feet at the creation of a limited maritime coordination function in the Black Sea" - the idea that it had previously promoted (Toucas, 2018).

The Balance of Threats: Competing Security Priorities in the Black Sea and the Middle East

Russia's invasion of Ukraine and illegal annexation of Crimea have led to a dramatic change in the security situation in the Black Sea, detrimental to Turkey's interests. Militarization and nuclearization of the occupied Crimean peninsula, enhanced military modernization of Russian armed forces, including deployment of new types of strategic weapons in Crimea, development of a modern submarine fleet and widespread use of the electronic warfare tools have strengthened Russian ability to project its maritime and military power to the Black Sea basin, Eastern Mediterranean and far beyond. In fact, together with the occupied territories of Crimea and critical infrastructure in the territorial waters of Ukraine, Russia has got an opportunity to maintain control over a vast area reaching out to Turkey's national borders.

At the same time, the humanitarian situation on the occupied peninsula has quickly deteriorated due to the human rights violations (including against the Turkic Crimean Tatars) and attempts to change the demographical situation in Crimea. Not least important, Russia has continued to increase its military and naval capabilities in the Black Sea that, for the first time, after the dissolution of the Soviet Union, raised concerns among Turkish military experts.

As "Atlantic Council" analyst Stephen Blank sums up, in a couple of years following the illegal annexation, Moscow has built a combined arms force of land, sea, air and electronic forces fully capable of denying access to NATO forces seeking to enter the Black Sea during a potential conflict. Now it is building a similar network of anti-access area denial (A2/AD) capabilities against NATO in both the eastern Mediterranean and the Caucasus, in fact surrounding Turkey to the north, south and east by Russian troops and enhanced military presence in Crimea, East of in Ukraine, Syria, Armenia, and Georgian breakaway province of Abkhazia (Blank, 2016). 
Turkish experts warn that Russia's Black Sea and Syrian "A2/AD bubbles" should raise concerns in Turkey for several reasons. Firstly, because "they spell an end to the relative naval superiority that Ankara had established in the Black Sea, the Aegean Sea and the Eastern Mediterranean after the Cold War". Secondly, because they mean that Turkey will have "to redirect resources away from its ambitious build-up of force-projection platforms toward developing strategies and weapons to counter the Russian military presence". Besides, there is also a rightful concern that while Russian-Turkish relations appear better at this point of time, the future is uncertain and "if a crisis erupts similar to the November 2015 shooting down of a Russian Su-24 by a Turkish F-16, Ankara would face fearful odds against Moscow" (Kurtdarcan \& Kayaoglu, 2017). The biggest problem in this case would be to find oneself vis-à-vis Russia without traditional Western allies' support to deter its aggressive moves.

These changing dynamics supposedly should prompt the Turkish leadership to step up measures to deter Russia, in particular by strengthening cooperation with NATO partners. However, despite some expectations that after the occupation of Crimea Turkey would become a key security provider in the region as a NATO member and a major naval force, able to deter Russian growing military build-up, this did not happen.

One of the reasons explaining Turkish attempts to prevent a negative spill-over effect from contradictions around the Crimean issue to the generally positive dynamics in its dialogue with Russia has been a significant deterioration of the security situation in other regions (in particular, the Middle East and the Aegean Sea), which, unlike the occupied Crimea and the "frozen" conflicts in GUAM countries, pose an existential threat to Turkey.

A 2020 Kadir Has University survey showed that despite all important processes unfolding in the Black Sea, the region was not even in Turkey's top five security priorities. According to respondents, the main threats to the Turkish national security included the escalation of tensions in Syria, Libya and the Eastern Mediterranean, humanitarian and diplomatic crisis over refugees, and Kurdish terrorism (namely, PKK and YPG who get their support, as goes a popular belief, from the United States) (Türkiye Eğilimleri, 2020). Interestingly enough, it is the same United States (Turkey's strategic partner and NATO ally) that tops the list of national security threats to Turkey for many years in row (championing with $81,3 \%$ in 2019), leaving far behind such "traditional rivals" as Russia, Syria, Armenia or Cyprus (Research on Public Perceptions, 2019).

In this regard, Erdogan's statements at the 2019 NATO London Summit were quite telling. His initial promises to block the Alliance's defence plans 
for Poland and the Baltic States in case of Brussel's failure to recognize Kurdish YPG groups as a terrorist organization have clearly demonstrated that for Turkey "NATO's eastern flank problem" (Turkey Threatens, 2019) extends not along the Baltic Sea but across its border with Syria. And it is this region that is regarded in Ankara as a number one security priority.

Secondly, many Turkish officials still share traditional fears that expanding NATO's military capabilities near Russia's borders would provoke an undesirable escalation on the part of Moscow, which could be otherwise avoided. At the same time, there are expectations in Turkey that the policy of "appeasement of the aggressor" and the continuing "constructive dialogue" with the Kremlin will help ensure the sustainable peace. Thus, although Ankara has not recognized the illegal annexation of Crimea and repeatedly defended Ukraine's territorial integrity, it has always avoided strong wording on Russian aggression in the region.

The same desire "not to poke the Russian bear" explains Turkey's weak reaction to the 2018 "Kerch incident". After Russia seized three Ukrainian vessels and took hostage 24 sailors, Turkey's Foreign Ministry issued a statement "emphasiz[ing] [the importance of] freedom of passage at the Kerch Strait" and "urg[ing] all parties to refrain from steps endangering regional peace and stability" (Press Release, 2018).

Some pro-government Turkish experts go as far as to suggest that Ukraine should also become a part of this "inclusive dialogue" whereas "[all] parties, including Ukraine, need to sit together to augment security cooperation in a wide region" (Yalçınlıkl1, 2017). On a political level, this approach includes calls to send back Ukrainian liaison officers and resume participation in the Operation Black Sea Harmony and BLACKSEAFOR, which has been suspended after 2014.

The "Jamestown" analyst Volodymyr Socor called this policy "a reality-denying position" saying that Ankara is "clinging to a status quo that no longer existed": "Turkey does not, and cannot on its own any longer, counterbalance Russia's threatening power, but neither does it work proactively with its NATO riparian and non-riparian allies to deal with this mounting challenge" (Socor, 2018).

This "reality-denying position" of Ankara "comes to terms with reality" when analysed through the prism of the balance of threat theory. Under the current circumstances, the United States is perceived in Turkey as a major source of potential threats in the region. Given the overall positive dynamics in the Turkish-Russian relations, allying with Russia - even though in a short-term perspective - is likely to bring more benefits that balancing against it. 
In Turkey, "having Russia on-board" is seen as a key to maintaining stability not only in the Black Sea, but also in the wider Middle East region. Therefore, it should be expected that any steps taken by Ankara in the Black Sea region will be checked for consistency with its goals in other areas and regions of higher priority. Besides, the Kurdish issue, which has long become a matter of national security rather than a foreign policy issue, will remain an important factor demanding its continuous cooperation with Russia.

Thus, the existence of more urgent threats in other regions, requiring Moscow's direct participation, to a large extent has determined Ankara's somewhat passive stance in the Black Sea. At the same time Russia's increasing military build-up in the Eastern Mediterranean and in Syria in close vicinity to the Turkish borders, has become a strong argument in favour of maintaining "friendly relations" with the Kremlin.

The Balance of Interests: Pragmatism as a Cornerstone of the Turkish Foreign Policy

Convergent interests and a number of joint Turkish-Russian projects in such strategic spheres as the defence industry, military-industrial complex and energy supplies have also played an important role in Turkey's alliance with Russia. After coming to power in the early 2000's, the Justice and Development Party has declared pragmatism as one of the pillars of the new "proactive" Turkish foreign policy, and its Black Sea regional dimension was no exception (Mikhelidze, 2017).

The period after the 2016 coup attempt (which is widely believed to have been orchestrated in the FBI/CIA headquarters and defeated with the generous support of the Russian intelligence services) witnessed an unprecedented rapprochement between Moscow and Ankara. It has been marked with burgeoning cooperation on a number of key issues, including de-conflicting efforts in Syria, supply of S-400 air defence systems to Turkey, energy cooperation on TurkStream gas pipeline, construction of nuclear power plant Akkuyu etc. This made Ankara's Black Sea policy largely determined by the desire to resume full-speed cooperation with Russia and to avoid any moves that could potentially threaten the implementation of these plans.

Furthermore, other factors usually ignored by the neorealist theory which mainly focuses on the systemic and state levels of analysis, have been essential in the Russian-Turkish relations. Personal ties between both presidents and their similar style of governance, "simplified" decision-making process and state systems with a highly consolidated power vertical (unlike the clumsy and time-consuming bureaucratic procedures of the Western democracies), similar foreign policy ideologies and values (Eurasianism, anti-Americanism, historical perception of the Black Sea as an "inner sea" etc.) 
- a combination of all these factors have significantly contributed to the formation of a "common agenda", distinct from the Euro-Atlantic one.

With this being said, one should not overestimate the level of trust in the Turkish-Russian relations. The historical memory bears dozens of examples of Moscow's treacherous acts, while modern geopolitical realities entail conflicting interests in Syria, Libya, Crimea and the wider Black Sea area (Nagorno Karabakh, Abkhazia, Southern Ossetia, and Transnistria). The awareness of this complex interdependence makes Ankara seek for a diversification of its foreign policy choices that would allow it to counterbalance the growing influence of its "strategic partner" (since early 2000's Russia holds a status of Turkey's strategic partner as well as the USA, Ukraine, and Georgia).

While Turkey opposes NATO presence in the Black Sea basin on a permanent basis, it takes active part in joint maritime exercises and training drills, like PASSEX or Sea Breeze, designed to increase interoperability of the participating countries on sea, land and air.

Turkey has always paid attention to maintaining close cooperation with Ukraine and Georgia, both within the NATO framework and on a bilateral level. Ankara remains a strategic partner and important political-military ally of Ukraine and has significantly intensified defence and security cooperation with Kyiv in recent years, including supply of Turkish professional communication systems and combat UAV's to the Armed Forces of Ukraine. In 2019, both sides declared creation of a joint Ukrainian-Turkish venture "Black Sea Shield" aimed at combining technological and industrial potential of the two countries in the aviation, security and defence spheres (Ukraine and Turkey, 2019). As Turkey's disagreements with Russia on Crimea, Libya and Syria leave less and less shared interests holding two countries together, Ankara sees Ukraine as a feasible alternative to ease its dependence on military-technical cooperation with Russia and create national autonomous defence industrial complex of full cycle.

One of the other issues that the Turkish leadership will still have to address is the issue of the Straits and the legal status of the new artificial "Canal Istanbul". In particular, it is still unclear whether the new canal will be subjected to the clauses of the Montreux Convention, which regulates the passage of the non-littoral states' warships through the Straits and imposes restrictions on their tonnage and duration of stay in the Black Sea basin.

The Preamble of the Convention defines the general term "the Straits" as "the Straits of the Dardanelles, the Sea of Marmara and the Bosporus". However, it rests uncertain about any other artificial waterways (Convention Regarding, 1936, c. 225-227). Experts agree that when it comes to commer- 
cial vessels, Ankara has every right not only to charge a fee for the passage through an artificial canal located within the sovereign territory of Turkey, but also to regulate shipping traffic in accordance with the provisions of national law. It is much more difficult to understand the legitimacy of application of the Montreux restrictions on the warships of non-Black Sea countries, which will get to the Black Sea basin through a new "entry point", bypassing the Bosporus.

The heated debate among maritime law experts flared up with a new vigour after president Erdogan had recently said that the Convention was only "binding" for "the Straits", whereas Canal Istanbul would be kept "totally outside Montreux". As he put it, "the Canal will function as Turkey's national waterway", therefore "it has no relation to the Montreux regime whatsoever" (Hincks, 2020). If so, this would mean a drastic change in Turkey's almost century-long tradition of seeing the Montreux Convention as the Alpha and Omega of its Black Sea policy that had to be respected no matter what.

Any attempts to suggest the amendments to upgrade the 1936 Convention in line with the technical characteristics of modern warships, have been met in Ankara with a strict rejection. As one Turkish Ambassador noticed, obviously "Russia would [also] prefer the continuation of the Montreux order to avoid new uncertainties and challenges, particularly after the annexation of Crimea with Sevastopol home to its Black Sea Fleet... For centuries, Russia's dream was to have Istanbul, the Marmara region and the Straits. Now, this can no longer be the case ..." (Tuygan, 2020).

Furthermore, after the mounting offensive of Russian-backed Assad forces in Syria, several Turkish media reported Erdogan as "considering closure of Bosporus for the passage Russian vessels" as one of the possible options "on the table" in case of further escalation in the Syrian Idlib (Turkey May Close, 2020).

In the meantime, given the current level of tensions in its relations with the West, Ankara is unlikely to provoke a serious crisis in relations with Russia by opening the Black Sea basin to the NATO warships. However, if the Montreux provisions will not be valid for the new waterway, Canal Istanbul might create a completely different geopolitical landscape in the region. This would give Ankara much more flexibility in foreign policy decision-making and would considerably strengthen its hand at a negotiation table with both Moscow and Washington, allowing it to maintain a fragile balance of power, threats and interests between two competing strategic partners.

\section{Conclusions}

The post-Cold War system of international relations is characterized by the emergence of new regional powers in different parts of the world and the 
regionalization of the global security architecture. Although the power of the United States is still largely overwhelming, regional states have been playing an increasingly active role within their regional subsystems.

With a gradual transition of the world system from unipolar to a multipolar structure, the mechanisms of balance of power, threat and interests have played a key role in the redistribution of power between the newly emerging regional leaders, with Turkey being one of them. Therefore, the neorealism theory, which provides relevant theoretical and methodological basis for studying these structural shifts, has been instrumental in analysing Turkey's policy in the Black Sea region. At the same time, the constructivist methodology has allowed to analyse the role of cultural, ideological and social factors as well as the influence of collective memory and historical traumas on the formation of Turkey's strategic culture.

Taking into account the current state of play in the Black Sea region and recent dynamics in Turkey's relations with the key players (in particular, US, NATO and Russia), three scenarios for the mid-term future seem worthy of consideration.

1. Turkey's withdrawal from NATO and institutionalization of its alliance with Russia. Though many experts tend to talk about the "historical low" in Turkey's relations with Europe and a deep crisis in the transatlantic partnership, the extreme scenario of Turkey's "abandoning the West" looks highly improbable. The shared desire to limit US and NATO influence in the Black Sea makes Ankara and Moscow tactical allies, but does not help build strategic partnership in the long run. Neither does it add to the mutual trust of traditional rivals. No matter how successful the cooperation between the two countries might be at certain periods of time, historically, strategically and psychologically, the Turkish-Russian relations remain in the paradigm of competition for regional leadership and control over the Straits.

2. Refusal of cooperation with Russia amid escalating tensions over Libya, Syria, Crimea (or other contested areas) is also unlikely, given shared interests of Turkey and Russia in other regions and a number of joint projects in strategically important areas. In times of crisis with Russia, Ankara may be more willing to develop naval and military cooperation with US and NATO allies. However, it is more likely that Turkish leadership will use a possibility of NATO's enhanced presence in the Black Sea as a bargaining chip in its dialogue with Russia, rather than as a real opportunity to strengthen the Alliance on the ground (be it on land or at sea).

3 . It is, thus, highly likely that Turkey will continue a pragmatic policy of balancing between Russia and the West, guided by its own national interests and the desire to maintain a favourable status quo. This means that by 
deepening cooperation and entering into situational coalitions with Russia and/or other regional players (i.e. Iran), Ankara will still maintain its longterm strategic relations with Washington.

At the same time, it should be expected that Turkey will become increasingly active and independent in its own regional initiatives, often at the expense of its cooperation with US or running counter to its NATO commitments, if the developments in the neighbourhood will require. Turkey's pragmatic balance between Russia and the United States remains a cornerstone of Ankara's foreign policy, and there is no reason to believe that this may change in the foreseeable future.

\section{References}

1. Babacan, A. (2008, 23 September). Calming the Caucasus. The New York Times. Retrieved from http://www.nytimes.com/2008/09/23/opinion/23ihtedbabacan.1.164 07371.html

2. Becker, D. (2014). Memory and Trauma as Elements of Identity in Foreign Policy Making. In E. Resende, D. Budryte (Eds.) Memory and Trauma in International Relations: Theories, Cases and Debates, 57-74. Routledge.

3. Blank, S. (2016). Putin's Dream of the Black Sea as a Russian Lake. Newsweek. Retrieved from http://www.newsweek.com/putin-dream-black-sea-russianlake-476321

4. Brooks, S. \& Wohlforth, W. (2002). American Primacy in Perspective. Foreign Affairs, 81 (4), 20-33.

5. Celikpala, M. (2010). Escalating Rivalries and Diverging Interests: Prospects for Stability and Security in the Black Sea Region. Southeast European and Black Sea Studies, 10 (3), 287-302.

6. Cohen, A. \& Conway, I. (2006). U.S. Strategy in the Black Sea Region. Backgrounder, 1990. The Heritage Foundation.

7. Convention Regarding the Regime of the Straits, Montreux (1936). United Nations Treaty Series, 173 (4015). Retrieved from https://treaties.un.org/doc/ Publication/UNTS/LON/Volume\%20173/v173.pdf

8. Devlen, B. (2014). Don't Poke the Russian Bear: Turkish Policy in the Ukrainian Crisis. Policy Brief of the Norwegian Peace-Building Resource Center.

9. Flanagan, S. \& Larrabee, S. (2020). Turkey's Nationalist Course: Implications for the U.S.-Turkish Strategic Partnership and the U.S. Army. RAND Corporation Research Report. Retrieved from https://www.rand.org/pubs/ research_reports/RR2589.html

10. Hincks, J. (2020). How the Kanal Istanbul Is Dividing Erdogan's Turkey. Time. Retrieved from: https://time.com/5783560/canal-istanbul-erdoganimamoglu-infrastructure/

11. Hopf, T. (1998). The Promise of Constructivism in International Relations Theory. International Security, 23 (1), 171-200.

12. Huntington, S. (1999) The Lonely Superpower. Foreign Affairs, 78 (2), 35-49. 
13. Koru, S. (2017). Turkey's Black Sea Policy: Navigating Between Russia and the West. Black Sea Strategy Papers. Retrieved from https://www.fpri.org/ article/2017/07/turkeys-black-sea-policy-navigating-russia-west/

14. Kurtdarcan, B. \& Kayaoglu, B. (2017). Russia, Turkey and the Black Sea A2/ AD Arms Race. National Interest. Retrieved from http://nationalinterest.org/ feature/russia-turkey-the-black-sea-a2-ad-arms-race-19673

15. Layne, C. (2006). The Peace of Illusions: American Grand Strategy from 1940 to the Present. Ithaca: Cornell University Press.

16. Lynch, D. (2003). A Regional Insecurity Dynamic. In D. Lynch (Ed). The South Caucasus: A Challenge for the EU, 10-22, Paris: EUISS.

17. Mearsheimer, J. (2001). The Tragedy of Great Power Politics. N.Y.: Norton \& Co.

18. Mikhelidze, N. (2017). Turkey's Policy in the Black Sea Region: Oscillating Between Pragmatism and Opportunism. In S. Toperich \& A. Ünver Noi (Ed.) Turkey and Transatlantic Relations, 133-149, Washington D.C.: Center for Transatlantic Relations.

19. Petriashvili, S. (2015). Where is the Black Sea Region in Turkey's Foreign Policy? Turkish Policy Quarterly, 14 (3), 105-112. Retrieved from http:// turkishpolicy.com/article/777/where-is-the-black-sea-region-in-turkeysforeign-policy\#_ftn16

20. Press Release Regarding the Tension in the Azov Sea and Kerch Strait №321 (2018). Official web-site of the Ministry of Foreign Affairs of the Republic of Turkey. Retrieved from http://www.mfa.gov.tr/no-321-azak-denizi-ve-kercbogazindaki-gerginlik-hken.en.mfa

21. Schweller, R. (1994). Bandwagoning for Profit: Bringing the Revisionist State Back. International Security, 1, 72-107.

22. Snyder, G. (1997). Alliance Politics. Ithaca: Cornell University Press.

23. Snyder, J. \& Christensen, T. (1990). Chained Gangs and Passed Bucks: Predicting Alliance Patterns in Multipolarity. International Organization, 44 (2), 137-168.

24. Socor, V. (2005). Black Sea Watch. Eurasia Daily Monitor, 2 (34). Retrieved from https://jamestown.org/program/black-sea-watch/

25. Socor, V. (2018). Turkey Stalls NATO, Clings to Defunct Status Quo in the Black Sea. Eurasia Daily Monitor, 15 (116). Retrieved from https://jamestown. org/program/turkey-stalls-nato-clings-to-defunct-status-quo-in-the-black-sea/

26. Tol, G. (2019). Balance in the Black Sea: Complex Dynamic between Turkey, Russia and NATO. Middle East Institute Policy Analysis. Retrieved from https://www.mei.edu/publications/balance-black-sea-complex-dynamicbetween-turkey-russia-and-nato

27. Toucas, B. (2018). Turkey Has No Allies in the Black Sea, Only Interests. CSIS Commentary. Retrieved from https://www.csis.org/analysis/turkey-hasno-allies-black-sea-only-interests

28. Turkey May Close the Bosphorus to Russia Warships. (2020). Middle East Monitor. Retrieved from https://www.middleeastmonitor.com/20200224turkey-may-close-the-bosphorus-to-russia-warships/ 
29. Turkey Threatens to Block NATO's Baltic Defence Plan Over YPG. (2019). Aljazeera. Retrieved from https://www.aljazeera.com/news/2019/12/turkeythreate ns-block-nato-baltic-defence-plan-ypg-191203083651527.html

30. Turkish Foreign Policy (2019). Research on Public Perceptions by Kadir Has University. Retrieved from https://www.khas.edu.tr/en/haberler/researchpublic-perce ptions-turkish-foreign-policy-2019

31. Türkiye Eğilimleri - 2019 (Тенденції Туреччини - 2019). (2020). Public Opinion Survey by Kadir Has University. Retrieved from https://www.khas. edu.tr/sites/khas.edu.tr/files/inlinefiles/TE2019_TUR_BASIN_15.01.20\%20 WEB\%20versiyon\%20power point_0.pdf.

32. Tuygan, A. (2020). The Montreux Convention: Russia's Perspective. EDAM. Retrieved from https://edam.org.tr/en/the-montreux-convention-russiasperspective/

33. Ukraine and Turkey Set Up a Joint Venture in Precision Weapons and Aerospace Technologies. (2019). Official web-site of the National Security and Defence Council of Ukraine. Retrieved from https://www.rnbo.gov.ua/en/ Diialnist/3345.html

34. Walker, J. (2008) Reexamining the U.S.-Turkish Alliance. The Washington Quarterly, 31 (1), 93-109.

35. Walt, S. (1985). Alliance Formation and the Balance of World Power. International Security, 9 (4), 3-43.

36. Waltz, K. (1979). Theory of International Politics. N.Y.: Random House.

37. Whiteneck, D. (2001). Long-Term Bandwagoning and Short-Term Balancing: The Lessons of the Coalition Behaviour from 1792 to 1815. Review of International Studies, 27, 151-168.

38. Winrow, G. (2007). Turkey and the Greater Black Sea Region. In N. A. Guney (Ed). Contentious Issues of Security and the Future of Turkey, 121-134. Ashgate Publishing.

39. Wohlforth, W. (1999). The Stability of a Unipolar World. International Security, 24 (1), 5-41.

40. Yalınkılıçl1, E. (2017, October 16). Turkey's "Near Abroad" in the Black Sea: Ankara's Predicament Between Kiev and Moscow. Daily Sabah. Retrieved from https://www.dailysabah.com/op-ed/2017/10/16/turkeys-near-abroad-inthe-black-sea-ankaras-predicament-between-kiev-and-moscow 


\section{CHAPTER 3 \\ ANNEXATION OF CRIMEA: LEGAL AND SECURITY PERTURBATIONS}

(Sergii Glebov)

\section{Introduction}

If we agree that the history of mankind is a history of wars, we should also agree that the Russian Federation has been doing its best to prove such an old-age dramatic adage in a chain of historic events in the XXI century. At the same time, starting from the WWI, since the WWII, and especially after the end of the Cold War, a certain part of mankind was trying to avoid warfare- at least within a widening circle of democratic states. A certain amount of hope, especially in Europe, to embrace Newly Independent States (NIS), including post-Soviet Russia, and to end with that kind of history (if not with the next stage of the clash of civilizations) became feasible after the formal disappearing of the USSR. At the same time, the new world order in the post-bipolarity began to languish by the end of the century. Consequently, the post-bipolar global re-ordering became much more complicated with Russia's use of hybrid mechanisms of waging proxy-wars against ex-Soviet republics and the rest of the democratic world to justify its own vision of the future world order. The war imposed on Ukraine, and the ensuing Russian military aggression, brought us back to the times of the Cold War and revived the days of triumph for the neo-realists. As Steven Rosefielde from the University of North Carolina, Chapel Hill, admits, "Russia's annexation of Crimea on March 18, 2014, appears to herald the end of the post-Soviet world order founded on partnership and the West's Wilsonian idealist concepts of the rule of law, democracy, and the sanctity of national independence" (2017, p. 45). The Western triangle USA-NATO-EU appeared to be not only an enemy but a major competitor to Kremlin in restoring dividing lines while designing the 'old school' spheres of influence in the post-Cold War era. Russia considered this threesome's intention to share security guarantees and democracy-based values associated with NATO's and the EU's enlargements eastward a threat to itself.

So, quite idealistic, but nevertheless with some objective grounds, a hope to substitute the post-bipolar European history of wars by the history of peace finally failed in 2014 with the annexation of Crimea. "The Ukraine crisis is most likely not just a regional problem," Ms. Merkel, the German Chancellor, said in a speech at the Lowy Institute for International Policy in Sydney, Australia, in November 2014. "In this case, we see it affects us all." 
"Who would've thought," she continued, "that 25 years after the fall of the Wall, after the end of the Cold War, after the end of the division of Europe and the end of the world being divided in two, something like that can happen right at the heart of Europe?" (Smale, 2014). The Chancellor's question sounds quite rhetorical these days as far as "Putin's seizure of Crimea was so startling, so disruptive of Western expectations, that many leaders seemed to forget that he had been the leader of Russia for the last decade and a half," and definitely "not a new kid on the block" (Kalb, 2015, p. 2). What is more important nowadays is that the West can do little to preoccupy Putin's Russia's future in connection to the tragic events in Ukraine, even though the case with the annexation of Crimea in 2014 is quite instructive.

\section{Crimea as an object of collision: retrospective}

The strategic importance of the Crimean war hero Admiral Nakhimov's statement "who owns Crimea owns the Black Sea" had delineated the importance of the Black Sea navy base of Sevastopol for the Russian Empire as well as the importance of the whole Black Sea region for the Russian Federation. As Vladimir Putin put it, it was "a region for which so many Russians gave up their lives during all the previous centuries" ("Transcript: Vladimir Putin's", 2014). The 'historical wound' to the empire inflicted by Nikita Khrushev, who decided in 1954 to reassign Crimea to Ukraine, was bleeding until February 2014. One might argue that the process in 1954 could have been more elaborate and better planned, but no matter how one judges the expeditiousness of the territorial reconfiguration, the main point to stress here is that it is incorrect to say (as some Russian commentators and government officials recently have) that Crimea was transferred unconstitutionally or illegally (Kramer, 2014). As Mark Kramer (2014), Director of the Cold War Studies Program at Harvard University concludes, "the legal system in the Soviet Union was mostly a fiction, but the transfer did occur in accordance with the rules in effect at the time". It is indeed difficult not to share such a conclusion when reference is made to internal territorial changes in a totalitarian country, where the official status of the Soviet Union as a federation was also fictitious given the authoritarian rule of the Communist party over the Soviet Union. Moreover, regardless of how the transfer was carried out, the interstate administrative border between the UkSSR and the RSFSR, as well as the territorial integrity of each of the parties, was confirmed by a bilateral agreement of November 19, 1990, signed by Boris Yeltsin and Leonid Kravchuk in Kyiv, still in the USSR (“Договор между РСФСР”, 1990). Later, this agreement was reconfirmed by the newly independent state of Ukraine and the Russian Federation, both of which recognized the succession of the UkSSR and the RSFSR, respectively. 
After the collapse of the USSR, the inviolability of the newly formed states' borders was confirmed by the Belavezha Accords on December 8, 1991, declaring that the Soviet Union would cease to exist and proclaimed the Commonwealth of Independent States (CIS) in its place ("Соглашение о создании", 1991). This document was signed and approved by the Ukrainian and the Russian side without any reservations regarding the territorial integrity of the states comprising the CIS. Moreover, a Declaration on the observance of the sovereignty, territorial integrity and inviolability of the borders of the member states of the Commonwealth of Independent States was adopted in Moscow on April 15, 1994 (“Декларация о соблюдении”, 1994). In this document, all parties, including the Russian Federation, expressed the intent to mutually respect sovereignty, and confirmed the territorial integrity and inviolability of each other's borders (“Декларация о соблюдении”, 1994). Russia, among other nuclear powers, via the 1994 Budapest Memorandum on Security Assurances to Ukraine confirmed that it would "respect the independence and sovereignty and the existing borders of Ukraine" and "refrain from the threat or use of force against the territorial integrity or political independence of Ukraine, and asserted that none of its weapons would ever be used against Ukraine" ("Memorandum on Security", 1994). Under a broader, 'normative' meaning, the 1994 Budapest Memorandum appeared to be "perhaps the most famous example of agreement concluded by Ukraine with other states in respect of jus contra bellum" (Daulenov, 2018, p. 10). As Miras Daulenov, Director of the Academy of Legal and Economic Research at KAZGUU University in Astana insists, "despite the opinion of some authors about the non-binding character of the Budapest Memoranda, it may be regarded as a treaty, granting substantive rights and imposing legal obligations regulated by international law" (2018, p. 11). The fact that neither the rights nor the obligations entered into force is separate issue, related to the lack of effectiveness of bilateral and multilateral treaties and agreements in the modern international system.

The inviolability of borders and the territorial integrity of European states are confirmed by the Final Act of the Conference on Security and Cooperation in Europe of August 1, 1975. Both Ukraine and Russia joined the Helsinki Final Act which obliged the participating States to "refrain... from the threat or use of force against the territorial integrity or political independence of any State", and to "regard as inviolable all one another's frontiers as well as the frontiers of all States in Europe and therefore they will refrain now and in the future from assaulting these frontiers" ("Conference on Security", 1975). In conclusion, both sides signed an Agreement on the Russia-Ukraine state borders in January 2003 (“Договор между Российской”, 2003), which 
confirmed the existing borders between the two countries in accordance with the UN Charter, Helsinki Final Act.

Nevertheless, the annexation was not an unexpected outcome: the issue of Crimea and the related matter of the Black Sea Fleet and the status of Sevastopol was always a point of friction in Russian-Ukrainian relations. There had already been an attempt to proclaim the Russian status of Sevastopol (a city which was Ukrainian both de facto and de jure) when the Russian Parliament adopted a decree "On the status of the city of Sevastopol" on July 9, 1993 ("Постановление ВС РФ", 1993). The decree cited a "Russian federal status for the city of Sevastopol within the administrative and territorial borders of the city district as of December 1991", (paragraph 1) and entrusted the appropriate parliamentary committee to incorporate the federal status of Sevastopol into the Russian Constitution (paragraph 4) ("Постановление ВC PФ", 1993). This provocative intention from the side of the supreme legislative body of Russia was condemned by the UN Security Council under the presidency of Sir David Hannay. Noting the groundlessness of Russia's claims, the UN Security Council confirmed the territorial integrity of Ukraine and the inviolability of its borders ("Complaint by Ukraine", 1993). In his response to a letter from the Ministry of Foreign Affairs of Ukraine requesting a qualified assessment of the Decree of the Supreme Council of the Russian Federation "On the Status of the City of Sevastopol" dated July 9, 1993, Sir David Hannay emphasized that this decision had no legal force ("Complaint by Ukraine", 1993). In any case, the Decree was in violation of paragraph 4 of Article 2 of the UN Charter, which forbids any threat or use of force against the territorial integrity or political independence of any state ("Charter of the United", 1945).

It is noteworthy that in his speech about this issue to the UN Security Council in the summer of 1993, the Russian representative emphasized that the decree adopted on 9 July 1993 by the Supreme Soviet concerning the status of Sevastopol diverged from the policy of the President and the Government of the Russian Federation. He contended that his country "remained dedicated to the principle of the inviolability of the borders within the Commonwealth of Independent States and would strictly abide by its obligations under international law, the Charter and the principles of CSCE" ("Complaint by Ukraine", 1993). The Russian representative also assured the UN Security Council, that "regarding its relations with Ukraine, the Russian Federation would continue to be guided by its bilateral treaties and agreements and in particular those concerning respect for each other's sovereignty and territorial integrity" ("Complaint by Ukraine", 1993). This seemingly paradoxical polyphony in Russian foreign policy on the issue of Sevastopol's status in 
1993 can be explained by the sharp political dissent between Yeltsin's administration and the Parliament at the time - which resulted in the October 1993 shelling of the Parliament. This ambivalence in Russia's position on Sevastopol's status in 1993 lies in stark contrast to the political clarity and determination exhibited in the era of President Putin. Putin's February-March 2014 annexation campaign of Crimea had the full support of both chambers of the Russian Parliament and of the entire political apparatus of the country.

The risk of a military clash between Russia and Ukraine in the Kerch strait area was also on the table of bilateral concerns back during the 2003 crisis over the Tuzla Island. The Tuzla incident confirmed the Russian intent to place the Kerch strait under full Russian sovereignty. The annexation of Crimea by Russia in 2014 was not just about the land itself; and moreover, it was not just a symbolic act of reclaiming 'Russian' Crimea. The Russian motivation was much more pragmatic and deeply related to the history of relations not only between Ukraine and Russia, but also between Russia and the West both before 1991 and thereafter. It can be argued, that one of the primary reasons that Russia wanted to regain sovereignty over Crimea, was its perceived strategic importance for geopolitical control of the Black Sea region - to 'own Crimea' in order to 'own the Black Sea' - which became a top priority on the back of the emerging aggravations between Russia and NATO since the turn of the Century.

\section{The Black Sea Fleet and the 'pre-annexation' concerns}

It would not be an exaggeration to claim that the intense Russian interest in Crimea was always connected to the navy base of the Soviet Black Sea Fleet in Sevastopol. The Black Sea Fleet of the former USSR itself was a subject of negotiations between Russia and Ukraine since 1995, in regard to the division of the warships and the material infrastructure between the two countries. Russia, under the conditions of the Agreement on the Black Sea Fleet with Ukraine of June 9, 1995, secured 81.7\% of the Soviet Black Sea Fleet against 18.3\% for Ukraine ("Угода між Україною", 1995). At the same time, the issue of the Russian naval base in Ukraine always extended far beyond the confines of navy discourse and adopted agreements. While the post-1991 Russian claims on the former Soviet Black Sea Fleet and the

former Soviet Black Sea naval base in Sevastopol were understandable, the introduction of territorial claims was not. As Taras Kuzio (an author of "Russia-Crimea-Ukraine. Triangle of Conflict", 2007, and "The Crimea: Europe's Next Flashpoint?", 2010) claimed as far back as in 1995, the failure of attempts to solve the problem of the Black Sea Fleet lay precisely in Russia's inability to recognize the sovereignty of Ukraine over Crimea and Sevastopol (Кузьо, 1995, р. 45). 
The Russian Federation was basically the last country in the Black Sea region to recognize Ukraine's territorial integrity and its sovereignty over Sevastopol and Crimea in a bilateral 'big' political Treaty on Friendship, Cooperation, and Partnership between Ukraine and the Russian Federation signed on May 31, 1997 (“Договор о дружбе”, 1997). It is essential to note that this Treaty was signed right after Ukraine had agreed to keep Russia's part of the Black Sea Fleet in Sevastopol at least until 2017. A package of agreements on the Black Sea Fleet of the former USSR had been signed just a few days prior, on May 28, 1997 (“Соглашение между Российской Федерацией и Украиной о параметрах”, 1997; “Соглашение между Российской Федерацией и Украиной о статусе", 1997; “Соглашение между правительством", 1997). Despite the favourable terms for Russia, the 'Big' political Treaty remained unratified by the Federal Assembly of Russia for a long time, and was finally approved only on February 17, 1999 (Ukraine had ratified the Treaty a year before, on January 14, 1998). It is worth noting, that in the context of the on-going war of Russia against Ukraine, the latter expectedly announced its intention to not renew the treaty in September 2018, and hence it expired on April 1, 2019.

With the election of Viktor Yanukovich as President of Ukraine in 2010, the confident Russian statement that "the Black Sea Fleet will stay in Sevastopol as long as it is necessary for Russia" (“Российский адмирал”, 2007) materialized. The ratification of the so-called 'Kharkiv Pact' in the Ukrainian parliament on April 27, 2010, which prolonged the berthing of the Russian Black Sea fleet in Crimea until 2042, also proved that Ukraine failed to pass the test of its ability to pursue its pro-NATO aspirations. In addition to this, Yanukovich's Ukraine proclaimed its non-allied orientation with the "Law on the Basics of Internal and Foreign Policy" (“Закон України Про засади”, 2010) which was adopted by the parliamentary coalition of July 1, 2010. The withdrawal of Ukraine from its bid to join NATO signified that Russia secured its status as the sole military 'protector' of Ukraine. In general, the perceived threat of NATO played one of the crucial roles in Russia's decision to annex Crimea. The general idea of such a provocative message was that the Russian President tried to convince the Russians and the rest of the world that it was NATO which made him act while presenting the situation as if NATO had already deployed its bases in Crimea. It is enough to recall a tricky anti-NATO justification from the Russian President during his address to State Duma deputies, Federation Council members, heads of Russian regions, and civil society representatives in Kremlin on March 18, 2014 ("Address by President", 2014), and during his question-and-answer session with Russians in a studio audience on April 17, 2014 (“Transcript: Vladimir Putin's", 2014). 


\section{Russia's 'attempted' annexation of Crimea}

On February 27, 2014 masked Russian troops without insignia who pretended to be spontaneous local 'freedom fighters', took over the Crimean parliament, and captured strategic sites across Crimea. The pro-Russian government in Crimea formally initiated an illegal referendum on Crimea's status, and the declaration of Crimea's independence was eventually announced on March 16, 2014. The Supreme Council of Crimea and the Sevastopol City Council declared the independence of the Republic of Crimea from Ukraine and officially requested to join the Russian Federation the next day, on March 17. Russia recognized the Republic of Crimea as a sovereign state the same day. The Treaty on Accession of the Republic of Crimea to Russia was signed between representatives of the Republic of Crimea (including Sevastopol, with which the rest of Crimea briefly unified) and the Russian Federation on March 18, 2014. The treaty laid out terms for the immediate admission of the Republic of Crimea and Sevastopol as federal subjects of Russia. On March 19, President Putin submitted a treaty on Crimea's 'accession' by Russia and a constitutional amendment to set up two new federal subjects of the Russian Federation, to the State Duma. After the Russian Constitutional Court upheld the constitutionality of the treaty, the State Duma ratified it on March 20. The Duma also approved the draft federal constitutional law admitting Crimea and Sevastopol and establishing them as federal subjects. A day later, the treaty itself and the required amendment to article 65 of the Russian Constitution (which lists the federal subjects of Russia) were ratified by the Federation Council and almost immediately signed into law by Putin. On April 2, Russia formally denounced the 2010 'Kharkiv Pact' as well as the 1997 set of agreements on the Black Sea Fleet as of May 28, 1997.

In any case, the position of Ukraine was clear from the very beginning: it was Russian military intervention into Ukraine in February 2014 which resulted in the annexation of an integral part of its territory. Annexation is the "formal act by which a state asserts its sovereignty over a territory previously outside its jurisdiction" as The Columbia Electronic Encyclopaedia defines the term 'annexation' ("Annexation", 2017). The annexation of Crimea can in principle neither be classified as legal, nor as illegal, in the sense that the 'annexation' itself is a "possession taken of a piece of land or a country, usually by force or without permission" as the Cambridge Dictionary defines it ("Annexation", 2020). In the case of Crimea, it was removed from Ukraine's jurisdiction by force and without permission. In fact, as, for example, the Helsinki Final Act oblige, the Participating-states should also "refrain from any demand for, or act of, seizure and usurpation of part or all of the territory of any participating State" ("Conference on Security", 1975). 
The position of Russia in the context of the regional and global discourse on the annexation of Crimea centred on asserting that it merely constituted a peaceful reunification. As Russian President Vladimir Putin said at a CIS summit in the Kyrgyz capital on September 16, 2016, Moscow did not annex the Ukrainian peninsula of Crimea in 2014 but simply facilitated its reunification with Russia ("Putin Says", 2016). Right after the unlawful referendum in Crimea of March 2014, Russian Foreign Minister Sergei Lavrov argued that the term 'annexation', as used by some Western politicians, did not apply to the process of Crimea joining Russia and claimed that its use offended the inhabitants of the peninsula (“Лавров назвал”, 2014).

Meanwhile, the so-called 'Crimean status referendum' was neither in compliance with Ukraine's Constitution, nor with general democratic standards as per the assessment of the Council of Europe's Venice Commission. This position was adopted by the Commission on March 21, 2014, by invoking that "the Ukrainian Constitution prohibits any local referendum which would alter the territory of Ukraine" ("Opinion on", 2014). The Commission highlighted that the decision to call a local referendum in Crimea was not covered by the authority devolved to the authorities of the Autonomous Republic of Crimea by virtue of Article 138 of the Ukrainian Constitution. Such assessment of the 'referendum' was echoed by the UN General Assembly's Resolution 68/262 on the "Territorial integrity of Ukraine" of 27 March 2014, which underscored that "the referendum held in the Autonomous Republic of Crimea and the city of Sevastopol on 16 March 2014, having no validity, cannot form the basis for any alteration of the status of the Autonomous Republic of Crimea or of the city of Sevastopol" ("Territorial integrity", 2014).

In its unsuccessful attempt to twist the interpretation of an international law into validating the 'referendum', the Russian Federation invoked the right to self-determination of peoples as a foundation for Crimea's secession from Ukraine. It is notable that the Kremlin contended that the people of Crimea had exercised their 'free will' as to the right to self-determination. As the Russian Foreign Minister Sergei Lavrov stated on March 20, 2014 "the decision about the acceptance of the Republic of Crimea into the Russian Federation is based on the free will of the multinational people of Crimea during the referendum of the March" ("Speech by the Russian", 2014). In his assessment, "this decision corresponds to international law, including the principle of the sovereign equality of state and the right of people to self-determination, which is stated as a goal of the UN in its Charter" ("Speech by the Russian", 2014). Bill Bowring of the School of Law at the Birkbeck College of the University of London counters that "... Russia has quite simply got it 
wrong"; according to Bowring, "the right to self-determination was exercised by 'the people of Crimea', 'the Crimeans', although the only 'people' with a right to self-determination in Crimea is the Crimean Tatar people, an indigenous people of Crimea" (Bowring, 2018, p. 35). Although there is no fully accepted definition of 'peoples', references are often made to a definition proposed by UN Special Reporter Martínez Cobo in his study on discrimination against indigenous populations where "indigenous communities, peoples and nations are those which, having a historical continuity with pre-invasion and pre-colonial societies that developed on their territories, consider themselves distinct from other sectors of the societies now prevailing in those territories, or parts of them" ("Martinez Cobo", 1986). Moreover, it can be argued that it is the indigenous Tatars who suffered the most from Russia's invasion among all of Crimea's ethnic groups. Not surprisingly, the Crimean Tatar Mejlis deputy chairman Ilmi Umerov has publicly claimed that $95 \%$ of Crimean Tatars do not recognize the jurisdiction of the Russian Federation in annexed Crimea, even if they do not speak it out for obvious reasons (" $95 \%$ of Crimean", 2019).

It appears that Sergei Lavrov also "got it wrong" when he tried to relate the international law's right of 'peoples' to the Kremlin's will to deliver the right of 'self-determination' to the 'multinational people' of Crimea. As Slawomir Debski, the Director of The Polish Institute of International Affairs (PISM), asserts, Russia's armed aggression against Ukraine thus went hand in hand with Russian aggression against international law as soon as "the Russian government's activities relating to Crimea actually transcend the bounds of building a legal case - and as such can be regarded as a form of 'international law trolling', seeking to undermine, relativize and destroy the international legal order" (Debski, 2017, p. 14). "From this viewpoint", Debski continues, "the most destructive argument invoked by Russia to justify its action against Ukraine was its citing of earlier examples of international-law transgressions" (Debski, 2017, p. 14). One such example was the Russian President's reference to the Kosovo precedent (“Address by President”, 2014) - even though it can be argued that "politically, the annexation of Crimea would have been more difficult had the Kosovo precedent not come before it" (Czaplinski, 2017, p. 35). Never the less, Patrycja Grzebyk from the Institute of International Relations, University of Warsaw, notes in relation to the Crimea events, that "the International Court of Justice has not sanctioned the so-called Kosovo Precedent, i.e. the right to secession, as it has stated, not that Kosovo has a right to secession, but only that the fact of issuing a declaration of independence cannot be considered a violation of International law" (Grzebyk, 2017, p. 145). 
At the same time, Christian Marxsen (the Max Planck Institute for Comparative Public Law and International Law in Heidelberg) admits that even though "the right to self-determination is a fundamental principle of international law and is incorporated in Article 1 (2) UN Charter... it is commonly understood that the concept of self-determination may not be used to disaggregate the territory of existing nation-states" (Marxsen, 2014, p. 385). Marxsen refers to the Friendly Relations Declaration, which states that the principle of self-determination may not be "construed as authorizing or encouraging any action which would dismember or impair, totally or in part, the territorial integrity or political unity of sovereign and independent States - as long as States respect the principle of equal rights and self-determination in relation to minority groups" (Marxsen, 2014, p. 385). In reflecting on the various scholarly arguments set forth on this issue, Simone F. van den Driest, an Assistant Professor at the Grotius Centre for International Legal Studies, Leiden University, draws the following conclusion: "All in all, it should be concluded that the arguments involving an alleged right to self-determination and (remedial) secession as advanced by the Crimean and Russian authorities in attempting to justify the events on the Crimean Peninsula cannot be upheld. On the contrary: Crimea's unilateral secession from Ukraine clearly was illegal under international law" (van den Driest, 2015).

Coming back to Russian Secretary of State Lavrov's displeasure at the use of the term 'annexation', it must be noted that this somehow ironically corresponds to the official position of Kyiv in regard to the events of February-March 2014. The subsequently enacted relevant law of Ukraine makes no reference to any "annexation" or "annexed territory" but refers to the land territory of the Autonomous Republic of Crimea along with the "internal sea waters and the territorial sea of Ukraine around the Crimean Peninsula, the territory of the exclusive (maritime) economic zone of Ukraine along the coast of the Crimean Peninsula and adjacent to the coast of the continental shelf of Ukraine" as "temporarily occupied territories" (article 3 of the 2014 Ukrainian bill "On securing the rights and freedoms of the people and the legal regime for the temporarily occupied territory of Ukraine") ("Закон України Про забезпечення", 2014).

From a strategic standpoint, and in order to advance its demand for the restoration of its sovereignty over Crimea within the context of international law, it was important for Ukraine to underscore the conditionality of the occupation as de jure to maintain a de facto status quo of the annexation while not recognizing it. Valentina Azarova (Koç University Law School and the Center for Global Public Law in Istanbul) uses the term 'occupation' in reference to "situations of occupation maintained through illegal force in 
pursuit of the territory's acquisition or secession" (Azarova, 2018, p. 43). In the Commentary of 1958 to the Convention (IV) regarding the Protection of Civilian Persons in Time of War, it is stated in reference to the Article on "Annexation": "the occupation of territory in wartime is essentially a temporary, de facto situation, which deprives the occupied Power of neither its statehood nor its sovereignty; it merely interferes with its power to exercise its rights. That is what distinguishes occupation from annexation, whereby the Occupying Power acquires all or part of the occupied territory and incorporates it in its own territory" ("Convention (IV)", 1958).

The conclusion of the Commentary's authors is even more important: it is noteworthy that the reference to annexation in the aforementioned article cannot be considered as implying recognition of this manner of sovereignty acquisition. The preliminary convention work on this subject confirms that. In order to more clearly underline the unlawful character of annexation in wartime, the government experts of 1947 proposed adding the adjective 'alleged' before the word 'annexation' ("Convention (IV)", 1958). The adjective 'attempted', used by US Secretary of State Rex Tillerson on December 7, 2017 in front of the Russian Foreign Minister at the OSCE meeting in Vienna, highlights the same logic: "We will never accept Russia's occupation and attempted annexation of Crimea" The US and its Western Allies placed special attention on conceptually and legally framing the Russian occupation of Crimea as an 'attempted annexation' in order to underscore their lack of recognition of any de facto status quo created by the Russian actions. As the next US Secretary of State Michael Pompeo stated in the Crimea Declaration of July 25, 2018: "Russia, through its 2014 invasion of Ukraine and its attempted annexation of Crimea, sought to undermine a bedrock international principle shared by democratic states: that no country can change the borders of another by force" ("Crimea Declaration", 2018).

In sharing her view that 'Russia's activities in Crimea raise urgent questions about... the appropriateness of the use of the legal category of "belligerent occupation' in contemporary situations of foreign control over territory" (Azarova, 2018, p. 42), Azarova identifies the current status of Crimea "as an illegal territorial regime based on objective illegality that results from violations of peremptory norms of international law (jus cogens) intended to change the international status of the territory, as well as its government system and demographic characteristics" (Azarova, 2018, p. 43). While Crimea was simultaneously "allegedly annexed" in a de jure sense and "belligerently occupied" in a de-facto sense, it is indisputable that Russia invaded the Ukrainian territory of Crimea and after certain parts of the Donbas and Luhansk regions in the West of Ukraine. By undertaking an invasion via combat troops who 
did not wear insignia, Russia's attempted denial of any direct involvement in the military aggression failed shortly after the event. Initially, as of March 4, 2014, the Russian President Vladimir Putin openly denied any involvement of the Russian Armed Forces, by claiming that the combat troops were 'local self-defence units' ("Vladimir Putin answered", 2014). But, in less than two months during a question-and-answer session with Russian citizens in a studio audience on 17 April 2014, Putin had to confess twice that the masked uniformed troops without insignia who took over the Crimean parliament and other local strategic sites were indeed Russian soldiers: "Of course, the Russian servicemen did back the Crimean self-defence forces. They acted in a civil but a decisive and professional manner" ("Transcript: Vladimir Putin's", 2014). A little later during that session Putin made the following statement: "Russia did not annex Crimea by force. Russia created conditions - with the help of special armed groups and the Armed Forces, I will say it straight - but only for the free expression of the will of the people living in Crimea and Sevastopol" ("Transcript: Vladimir Putin's", 2014). At the same time the Helsinki Final Act states that "all peoples always have the right... to determine... their internal and external political status... and to pursue as they wish their political, economic, social and cultural development", but only under conditions of "full freedom and without external interference" ("Conference on Security", 1975). So, the abovementioned Putin's confession, among other things, leads to open recognition of the fact of violation of one of the main sources of modern international law by the Russian president, and, among other things, completely refute the words of the same Sergei Lavrov on the 'freely expressed will', which a priori cannot take place at gunpoint.

The initial denial of any direct involvement of the Russian servicemen in attacking Crimea was understandable given the context of international law. By acknowledging the opposite, Russia's actions would clearly and directly fall under the definition of 'aggression' as per the 1974 UN 3314 Declaration on the Definition of Aggression. Article 3, paragraph A of the Declaration allows for no misinterpretation, stating that regardless of any declaration of war "...the invasion or attack by the armed forces of a State of the territory of another State, or any military occupation, however temporary, resulting from such invasion or attack, or any annexation by the use of force of the territory of another State or part thereof was qualified as an act of aggression" ("Definition of Aggression", 1974).

On a different note but still in regard to international law, the Charter of the United Nations in its chapter 1, article 2, paragraph 4 forbids any threat or use of force against the territorial integrity or political independence of any state, or in any other manner inconsistent with the Purposes of the United Na- 
tions ("Charter of the United", 1945). Generally speaking, this Article 2(4) of the UN Charter appears to be one of the key reference principles for issues relating to aggression in the international arena. It appears to be a quintessence of the jus ad bellum (law on the use of force) or jus contra bellum (law on the prevention of war) which seeks to restrict the resorting to force between UN member-states. As Miras Daulenov suggests, "perhaps the most important interpretation of Article 2(4) of the UN Charter, which might be applicable to the situation in Ukraine, is the recognition that the territory of a state shall not be the object of military occupation resulting from the use of force. For this reason, no territorial acquisition resulting from the threat or use of force shall be recognized as legal" (Daulenov, 2018, p. 10). Exceptions to this principle are of course provided for cases of self-defence or for actions following decisions adopted by the UN Security Council under chapter VII of the UN Charter. It is Article 51 of the Charter which provides an exception to the prohibition on the use of force as this is stipulated in Article 2(4) of the Charter. According to this document, the right of individual or collective self-defence can be exercised in the event of an 'armed attack' against a Member of the United Nations until the Security Council has taken measures necessary to maintain international peace and security. ("Charter of the United", 1945).

It is clear that Russia had no internationally approved right to act under the provisions of Article 51 when it exercised its use of force against Ukraine. It was the sovereign state of Ukraine which was the object of the Russian Federation's 'armed attack' in Crimea; the masked Russian servicemen wearing green military uniforms without insignia were not 'local self-defence units' representing the 'multinational people of Crimea', or 'the people of Crimea' as per initial Russia's rhetoric which the Russian president himself later denied. Thus, Daulenov concludes, "the organization of irregular forces and armed bands by Russia with the objective of a military occupation of (part of) Ukraine's territory is to be regarded as a violation of its international obligations" (Daulenov, 2018, p. 10). In this context, Russia has repeatedly violated its obligations, in particular in the framework of the Helsinki Final Act, which stipulates that "the participating States will, inter alia, refrain from direct or indirect assistance to terrorist activities, or to subversive or other activities directed towards the violent overthrow of the regime of another participating State" ("Conference on Security", 1975).

Not accidentally, the annexation of Crimea by Russia and the continued Russian hybrid aggression over Eastern parts of Ukraine in turn became part of a global agenda in international relations and law. With more than 100 countries having openly condemned its aggression against Ukraine, Russia finds itself internationally isolated on this issue. The list of countries which 
voted during the 80th plenary meeting of March 27, 2014, in favour of the already mentioned General Assembly's Resolution 68/262 on the "Territorial integrity of Ukraine" ("Territorial integrity", 2014) stands in sharp contrast to the only 11 countries which voted against the resolution. The United Nations General Assembly on 19 December 2016 adopted a resolution on human rights in Crimea, which became the first international document designating the Russian Federation as an occupying power, and the Autonomous Republic of Crimea and the city of Sevastopol as a temporarily occupied territory. The resolution confirmed the territorial integrity of Ukraine and reaffirmed the non-recognition of the annexation of the Ukrainian peninsula ("Situation of human", 2016). This conclusion logically reinforces one of the fundamental principles of international relations, which assumes that states have to "refrain from making each other's territory the object of military occupation or other direct or indirect measures of force in contravention of international law, or the object of acquisition by means of such measures or the threat of them" ("Conference on Security", 1975); thus, "no such occupation or acquisition will be recognized as legal" ("Conference on Security", 1975) what was clearly demonstrated by the civilized international community.

The Western powers are standing firmly in support of Ukraine. The position of the EU left no room for misinterpretation about its allegiances. On March 13, 2014, the European Parliament in its Resolution about the invasion of Ukraine by Russia firmly condemned "Russia's act of aggression in invading Crimea, which is an inseparable part of Ukraine and recognized as such by the Russian Federation and by the international community...", called "for the immediate de-escalation of the crisis, with the immediate withdrawal of all military forces present illegally on Ukrainian territory," and urged "full respect for international law and existing conventional obligations" ("Invasion of Ukraine", 2014). Just a few days later, on March 20-21, 2014, the European Council meeting's Conclusions document confirmed in paragraph 29 that the European Union remained committed to "uphold[ing] the sovereignty and territorial integrity of Ukraine" and did not and would not recognize either "the illegal referendum in Crimea", or the "illegal annexation of Crimea and Sevastopol to the Russian Federation" ("European Council", 2014). It must however be highlighted that the EU refrained from attaching the politically and judicially critical adjectives "alleged" or "attempted" to its references on "annexation". While the EU offered no direct practical help to Ukraine for its defence against Russia, it did impose sectoral commercial sanctions against Russia alongside the United States.

More than 6 years have now passed since Russia temporarily occupied Crimea and some parts of the Donetsk and Luhansk regions in the east of 
Ukraine. The so-called Minsk process and the Normandy Four made little progress in persuading Russia to de-occupy Ukrainian territories in the East, while the case of Crimea (which now also has a Kerch bridge connection with Russia) has been practically put on the backburner both by Ukraine and the international community. The matter of Ukraine's demand for the return of Crimea under its sovereignty remains confined to a slow-moving agenda of bilateral Ukraine-Russia relations. Both sides involved in this case, but especially Ukraine, recognize that there is no military solution, and that only political and diplomatic tools are left for any attempted resolution to this matter. At the same time, just as in 2014, the West is united in its position as to the current and future status it is ready to accept for Crimea. "NATO supports the sovereignty and territorial integrity of Ukraine. NATO does not and will not recognize Russia's illegal and illegitimate annexation of Crimea. All NATO allies are united in their condemnation of Russia's aggressive actions", NATO Secretary General Jens Stoltenberg said at a joint press conference with Ukrainian President Volodymyr Zelensky in Kyiv on October 31, 2019 ("Stoltenberg: NATO", 2019). A virtually identical position was expressed by US Secretary of State Mike Pompeo at a joint press conference with President Volodymyr Zelensky also in Kyiv on January 31, 2020 ("The United States will", 2020). Pompeo stated that he had thoroughly discussed relations between Ukraine and Russia with Ukrainian President Zelensky and added as a summary of the US position: "The United States is committed to protecting Ukraine's sovereignty and territorial integrity and continues to support Ukraine in joining NATO and moving closer to the European Union" ("The United States will", 2020). He also recalled within this context that the work of the US - Ukraine Strategic Partnership Commission was resumed in November 2018, and that the United States approved the Crimea Declaration, which in July 2019 clearly asserted that Crimea is part of Ukraine ("The United States will", 2020). Moreover, Pompeo stressed that in March of the previous year, the US coordinated the imposition of further sanctions against Russia with Canada and European allies in response to Russia's attack on Ukrainian vessels in the Kerch Straits, and also extended sanctions on Nord Stream 2 in December 2019 ("The United States will”, 2020). On its side, the European Union Delegation to the OSCE assured Ukraine that the EU remains fully committed to non-recognition of the illegal annexation of Crimea by Russia, via a statement it issued at a meeting of the OSCE Permanent Council in Vienna on February 27, 2020 ("European Union Delegation", 2020). The positions of the US, the EU, and other Western powers in respect to the Crimean issue, constitute a de facto adoption of Dr. Belen Giupponi's (School of Law, Social and Behavioural Sciences, Kingston 
University, London, the UK) theorization, that the acquisition of foreign territory through annexation is an illegal international act which places both States and international organizations under the obligation of non-recognition - since it is a result of a violation of peremptory norms (Giupponi, 2019, p. 154).

\section{Conclusion and predictions}

With its aggression against Ukraine and its 'attempted' annexation of Crimea in February - March 2014, Russia became the first and only former superpower, nuclear state and permanent member of the UN Security Council to illegally seize, temporarily occupy and integrate the territory of a neighbouring country. Moscow has openly displayed its will and determination to disrespect international law and use its military power in the pursuit of its geopolitical interests and ambitions. Russia's military aggression and hybrid war against Ukraine brought its relations with the West back to Cold War conditions and signalled a triumph for the neo-realist school of thought in international relations. Russia's deployment of force in 2014 can be viewed as a determination to no longer accept the results of a set of rules it did not endorse (D'Anieri, 2017, p. 277). Via its actions against Ukraine, Russia has already undermined global trust and collaboration in the emerging multipolar world order. Following this, "Crimean annexation consequently should not be seen as Putin's end game. He perceives it as the starting point for a politically sustainable long-term struggle for internal and external control inside Russia and across its periphery" (Rosefielde, 2017, p. 27). 'Ending the conflict will require, and will likely help shape, a new set of security arrangements in Europe', indeed, but it is also likely, that the conflict will endure 'until Russia accepts the West's vision for Europe or the West accepts Russia's... with Ukraine caught in the middle' (D'Anieri, 2017, p. 277). At the same time, there are escalating doubts about Russia's readiness to accept the West's calls for de-escalation of the situation in the east of Ukraine. A potential return of Crimea back to Ukraine seems to be completely out of the question, not least because any concession to the West is seen as an expression of weakness by the Kremlin. "Russia's power services distrust the West with some justification and won't be beguiled by American and EU professions of reason and goodwill" (Rosefielde, 2017, p. 27). Putin's Russia has clearly separated itself from the West and has withdrawn from any further discourse on the creation of a common European and Euro-Atlantic security and cooperation framework with a long-term perspective. Even if the West accepts Crimea's annexation, "Putin is likely to soldier on until the West comes to terms with the Kremlin's grievances (power) and negotiates an acceptable new world order" (Rosefielde, 2017, p. 27). 
Ukraine is in a precarious position, as it needs to ensure that its national interests do not end up being sacrificed in the name of some deceptive rapprochement between Russia and the West. While the cessation of hostilities in the Donbas region of Ukraine is a pragmatic possibility assuming that the West continues to press Russia towards this objective, a return of Crimea to Ukraine is extremely unlikely. Within the backdrop of increasingly vocal assertions from the side of Russia that "Russia can deploy nuclear weapons in Crimea since it is part of its territory" ("Deployment of Russian", 2015) and ongoing large-scale military drills on the peninsula, it appears that Russia is determined to turn Crimea into an impregnable fortress against NATO. Moreover, an entire Crimean case now touches upon Russian territorial integrity. The "Republic of Crimea" is considered a constitutional subject of the Russian Federation, while Sevastopol is being specified as a city of federal importance - alongside only Moscow and St. Petersburg - within the article 65 of the Russian Constitution ("The Constitution of the Russian", 1993). It would hence not be foolhardy to make the prediction that the so-called "annexation" of Crimea will not be reversed as part of any foreseeable mainstream future scenario.

\section{References}

1. $95 \%$ of Crimean Tatars do not recognize Russian jurisdiction in Crimea. (2019, August 14). ATR.ua. Retrieved from https://atr.ua/news/189783-95-ofcrimean-tatars-do-not-recognize-russian-jurisdiction-in-crimea

2. Address by President of the Russian Federation. Vladimir Putin addressed State Duma deputies, Federation Council members, heads of Russian regions and civil society representatives in the Kremlin. (2014, March 18). President of Russia. Retrieved from http://en.kremlin.ru/events/president/news/20603

3. Annexation. (2017). The Columbia Electronic Encyclopaedia, 6th ed. Retrieved from https://www.infoplease.com/encyclopedia/social-science/government/concepts/annexation

4. Annexation. (2020). The Cambridge Dictionary. Cambridge University Press. Retrieved from https://dictionary.cambridge.org/us/dictionary/english/annexation

5. Azarova, V. (2018). An illegal territorial regime? On the occupation and annexation of Crimea as a matter of international law. In Sayapin, S. \& Tsybulenko, E. (Eds.). The use of force against Ukraine and international law: jus ad bellum, jus in bello, jus post bellum, 41-72. Berlin Heidelberg: Asser Press by Springer-Verlag.

6. Bodner, M. (2014, January 22). Russia's 8 Most Memorable Davos Moments. The Moscow Times. Retrieved from https://www.themoscowtimes. com/2014/01/22/russias-8-most-memorable-davos-moments-a31309

7. Bowring, B. (2018). Who are the "Crimean People" or "People of Crimea"? The fate of the Crimean Tatars, Russia's legal justification for annexation, 
and Pandora's box. In Sayapin, S. \& Tsybulenko, E. (Eds.). The use of force against Ukraine and international law: jus ad bellum, jus in bello, jus post bellum, 20-40. Berlin Heidelberg: Asser Press by Springer-Verlag.

8. Charter of the United Nations. (1945, June 26). United Nations. Retrieved from http://www.un.org/en/sections/un-charter/chapter-i/index.html

9. Complaint by Ukraine regarding the Decree of the Supreme Soviet of the Russian Federation concerning Sevastopol. (1993, 20 July). United Nations. Retrieved from http://www.un.org/ar/sc/repertoire/93-95/Chapter\%208/EUROPE/96-95 8-22-UKRAINE.pdf

10. Conference on Security and Co-operation in Europe Final act. (1975, August 1). OSCE. Retrieved from https://www.osce.org/helsinki-final-act?download=true

11. Convention (IV) relative to the Protection of Civilian Persons in Time of War. Geneva, 12 August 1949. Commentary of 1958. Treaties, States Parties and Commentaries. (1958). International Committee of the Red Cross. Retrieved from https://ihl-databases.icrc.org/applic/ihl/ihl.nsf/ Comment. xsp?action=open Document\&documentId=C4712FE71392AFE1C12563CD$0042 \mathrm{C} 34 \mathrm{~A}$

12. Crimea Declaration. Press Statement. Michael R. Pompeo, Secretary of State, Washington D.C. (2018, July 25). The U.S. Department of State. Retrieved from https://www.state.gov/crimea-declaration/

13. Czaplinski, W. (2017). Self-determination - secession - recognition (remarks on the international legal background to the incorporation of Crimea into the Russian Federation). In Wierczynska, K., W. Czaplinski, W., Debski, S., \& Tarnogorski, R. (Eds.). The Case of Crimea's Annexation under International Law, 23-42. Warsaw: Wydawnictwo Naukowe Scolar.

14. D'Anieri, P. (2017). Ukraine and Russia: From civilized divorce to uncivil war. Cambridge: Cambridge University Press.

15. Daulenov, M. (2018). The legal nature of states' obligations towards Ukraine in the context of jus contra bellum. In Sayapin S. \& Tsybulenko E. (Eds.). The use of force against Ukraine and international law: jus ad bellum, jus in bello, jus post bellum, 4-19. Berlin Heidelberg: Asser Press by Springer-Verlag.

16. Debski, S. (2017). Law, politics and the Future of Crimea. In Wierczynska, K., W. Czaplinski, W., Debski, S., \& Tarnogorski, R. (Eds.). The Case of Crimea's Annexation under International Law, 13-19. Warsaw: Wydawnictwo Naukowe Scolar.

17. Definition of Aggression - UN Documents: Gathering a body of global agreements. (1974, December 14). United Nations. Retrieved from http://www. un-documents.net/a29r3314.htm

18. Deployment of Russian nuclear weapons in Crimea possible - Foreign Ministry. (2015, March 11). TASS. Retrieved from http://tass.ru/en/russia/782071

19. European Council Conclusions. (2014, March 20-21). European Council. Retrieved from http://www.consilium.europa.eu/uedocs/cms_data/docs/pressdata/en/ec/141749.pdf

20. European Union Delegation to the OSCE has assured that the EU remains fully committed to non-recognition of the illegal annexation of Crimea by Russia. (2020, February 28). Ukrinform. Retrieved from https://www.ukrinform. 
net/rubric-polytics/2886028-eu-annexation-of-crimea-is-an-act-we-will-never-recognize.html

21. Giupponi, B. O. (2019). Exploring the links between nationality changes and investment claims arising out of armed conflicts: the case of Russian passportization in Crimea. In Gómez K., Gourgourinis A., \& Cham C. (Eds.). International Investment Law and the Law of Armed Conflict, 153-172. Switzerland: Springer Nature Switzerland.

22. Grzebyk, P. (2017). The annexation of Crimea in the light of the definition of Aggression. Does prohibition of aggression apply to Russia? In Wierczynska, K., W. Czaplinski, W., Debski, S., \& Tarnogorski, R. (Eds.). The Case of Crimea's Annexation under International Law, 137-154. Warsaw: Wydawnictwo Naukowe Scolar.

23. Invasion of Ukraine by Russia, 2014/2627(RSP). (2014, March 13). European Parliament. Retrieved from http://www.europarl.europa.eu/sides/getDoc.do?type $=$ TA\&reference $=$ P7-TA-2014-0248\&language $=\mathrm{EN}$

24. Kalb, M. L. (2015). Imperial Gamble: Putin, Ukraine, and the new cold war, Washington, D.C.: Brookings Institution Press.

25. Kramer, M. (2014). Why Did Russia Give Away Crimea Sixty Years Ago? Wilsoncenter.org, CWIHP e-Dossier No. 47. Retrieved from https://www.wilsoncenter.org/publication/why-did-russia-give-away-crimea-sixty-years-ago

26. Martinez Cobo Study of the Problem of Discrimination Against Indigenous Populations, Sub-Commission on the Prevention of Discrimination and the Protection of Minorities, UN Doc. E/CN.4/Sub.2/1986/7/Add.4. (1981, July 30). United Nations. Retrieved from https://www.un.org/development/desa/ indigenouspeoples/about-us.html

27. Marxsen, Ch. (2014). The Crimea Crisis - An International Law Perspective. Zeitschrift für ausländisches öffentliches Recht und Völkerrecht (Heidelberg Journal of International Law), 74/2, 367-391.

28. Memorandum on Security Assurances in connection with Ukraine's accession to the Treaty on the Non-Proliferation of Nuclear Weapons. (1994, December 5). PIR Center. Retrieved from http://www.pircenter.org/media/content/ files/12/13943175580.pdf

29. Opinion on "whether the decision taken by the Supreme Council of the Autonomous Republic of Crimea in Ukraine to organise a referendum on becoming a constituent territory of the Russian Federation or restoring Crimea's 1992 Constitution is compatible with constitutional principles" adopted by the Venice Commission at its 98th Plenary Session, CDL-AD(2014)002. (2014, March 21-22). Venice Commission. Retrieved from https://www.venice.coe. int/webforms/documents/?pdf=CDL-AD(2014)002-e

30. Putin Says Crimea Not Annexed By Russia, It Was 'Reunified'. (2016, September 17). Radio Free Europe/Radio Liberty. Retrieved from https://www.rferl. org/a/putin-says-crimea-not-annexed-was-reunified-with-russia/27996702. html

31. Remarks at OSCE Plenary Meeting. Rex W. Tillerson, Secretary of State. Hofburg Palace, Vienna, Austria. (2017). The U.S. Department of State. Retrieved from https://www.state.gov/secretary/remarks/2017/12/276319.htm 
32. Rosefielde, S. (2017). The Kremlin strikes back: Russia and the West after Crimea's annexation. New York: Cambridge University Press.

33. Situation of human rights in the Autonomous Republic of Crimea and the city of Sevastopol (Ukraine): resolution A/RES/71/205/ adopted by the General Assembly. (2016, December 19). United Nations. Retrieved https://digitallibrary.un.org/record/855181? $\ln =\mathrm{ru}$

34. Smale, A. (2014, November 17). Merkel Issues Rebuke to Russia, Setting Caution Aside. The New York Times. Retrieved from https://www.nytimes. com/2014/11/18/world/europe/russia-deports-german-polish-diplomats-retaliation.html

35. Speech by the Russian Foreign Minister, Sergey Lavrov, and his answers to questions from deputies during the plenary session of the State Duma of the Russian Federation, Moscow. (2014, March 20). The Ministry of Foreign Affairs of the Russian Federation. Retrieved from https:/www.mid.ru/en/ web/guest/foreign_policy/news/-/asset_publisher/cKNonkJE02Bw/content/ id/69626 609-20-03-2014

36. Stoltenberg: NATO will never recognize Russia's annexation of Crimea. (2019, October 31). Kyiv Post. Retrieved from https://www.kyivpost.com/ ukraine-politics/stoltenberg-nato-will-never-recognize-russias-annexation-of-crimea.html

37. Territorial integrity of Ukraine, UN GA Resolution 68/262. (2014, March 27). GUAM. Retrieved from https://guam-organization.org/en/un-ga-resolution-68-262-territorial-integrity-of-ukraine/

38. The Constitution of the Russian Federation. (1993, December 12). The Ministry of Foreign Affairs of the Russian Federation. Retrieved from https://www. mid.ru/en/foreign_policy/official_documents/

39. The United States will never recognize Russia's annexation of Crimea and supports Ukraine's efforts to join NATO, U.S. Secretary of State Mike Pompeo has said. (2020, January 31). Ukrinform. Retrieved from https://www.ukrinform.net/rubric-polytics/2866950-us-will-never-recognize-russias-annexation-of-crimea-pompeo.html

40. Transcript: Vladimir Putin's April 17 Q\&A. (2014, April 17). The Washington Post. Retrieved from https:/www.washingtonpost.com/world/transcript-vladimir-putins-april-17-qanda/2014/04/17/ff77b4a2-c635-11e3-8b9a8e0977a24aeb_story.html

41. van den Driest, S. (2015). Crimea's Separation from Ukraine: An Analysis of the Right to Self-Determination and (Remedial) Secession in International Law. Netherlands International Law Review, 62, 329-363.

42. Vladimir Putin answered journalists' questions on the situation in Ukraine. (2014, March 4). President of Russia. Retrieved from http://en.kremlin.ru/ events/president/news/20366

43. Декларация о соблюдении суверенитета, территориальной целостности и неприкосновенности границ государств-участников Содружества Независимых Государств. (1994, 15 апреля). Політика $і$ час, 1994, 6, 8788. 
44. Договор между Российской Федерацией и Украиной о российскоукраинской государственной границе. (2003, 28 января). Президент России. Взято $3 \mathrm{http} / / \mathrm{kremlin} . r u /$ supplement $/ 1653$

45. Договор между РСФСР и УССР. (1990, 19 ноября). Ведомости Съезда народных депутатов РСФСР и Верховного Совета РСФСР, 1990, 27, Ст. 353.

46. Договор о дружбе, сотрудничестве и партнерстве между Российской Федерацией и Украиной. (1997, 31 мая). Бюллетень международных договоров, 1999, 7, 50-58.

47. Закон України «Про засади внутрішньої і зовнішньої політики». (2010, 1 липня). Відомості Верховної Ради України (ВВР), 40, ст. 527.

48. Закон України «Про забезпечення прав і свобод громадян та правовий режим на тимчасово окупованій території України». (2014). Вiдомості Верховної Ради (ВВР), 26, ст.892.

49. Кузьо, Т. (1995). Чеченська криза і «ближнє зарубіжжя», Політика $i$ час, $8,42-52$.

50. Лавров назвал оскорбительными заявления Запада об аннексии Крыма. (2014, 21 марта). Взгляд. Взято 3 https://vz.ru/news/2014/3/21/678310.html

51. Постановление ВС РФ от 09.07.1993 n 5359-1 «О статусе города Севастополя» (1993, 9 июля). Викитека. Взято з https://ru.wikisource.org/

52. Российский адмирал: Севастополь еще долго будет базой ЧФ. (2007, 23 июля 2007). Корреспондент. Взято з https://korrespondent.net/ukraine/politics/199880-rossijskij-admiral-sevastopol-eshche-dolgo-budet-bazoj-chf

53. Соглашение между правительством Российской Федерации и правительством Украины о взаиморасчетах, связанных с разделом Черноморского флота и пребыванием Черноморского флота Российской Федерации на территории Украины. (1997, 28 мая 1997). Бюллетень международных договоров, 1999, 10, 80-83.

54. Соглашение между Российской Федерацией и Украиной о параметрах раздела Черноморского флота. (1997, 28 мая 1997). Бюллетень международных договоров, 1999, 10, 34-37.

55. Соглашение между Российской Федерацией и Украиной о статусе и условиях пребывания Черноморского флота Российской Федерации на территории Украины. (1997, 28 мая 1997). Бюллетень международных договоров, 1999, 10, 74-80.

56. Соглашение о создании Содружества Независимых Государств. (1991, 8 декабря). Дипломатический вестник, 1992, 1, 3-6.

57. Угода між Україною та Російською Федерацією щодо Чорноморського флоту (укр/рос), 643_082. (1995, 9 июня). Верховна Рада Украӥни. Взято 3 https://zakon.rada.gov.ua/laws/show/643_082 


\section{CHAPTER 4}

\section{THE RUSSIAN BLACK SEA FLEET: IS THERE A PLACE FOR STRATEGIC DIMENSION?}

(Polina Sinovets)

\section{Introduction}

The beginning of 2020 was marked with the news:

From aboard the guided missile cruiser Marshal Ustinov, Supreme Commander in Chief of the Russian Armed Forces Vladimir Putin observed the joint exercises involving the Northern and Black Sea fleets underway in the Black Sea. Various missiles were fired during the exercises, including Kalibr cruise missiles and the Kinzhal hypersonic air-launched ballistic missile. (Joint exercises of Northern and Black Sea fleets, 2020).

Does this military activity somehow stand out from the wide range of Russian military trainings regularly organized by Moscow since the annexation of Crimea? The answer is "yes and no": on one hand Russians haven't deviated from their coercive military behavior, showing their military might again and again. But on the other the substance of their military trainings gives some food for thought.

Last October, the "Grom-2019" military trainings simulated Russian involvement in global nuclear war and resurrected the "nuclear card" in Russian military rhetoric (Гольц, 2020). The 2020 Black sea Russian naval trainings supported this argument to some extent.

One can argue that Russia is the biggest nuclear power, so one should not be surprised with its nuclear trainings. The most bothersome fact is that this time trainings involving a possible nuclear component took place at the Black Sea almost in the heart of Europe. Moreover, it was conducted in Crimea, which most world actors consider a territory of Ukraine. And it brings us back to the "escalation for de-escalation" principle usually denied by Russia and partially erased by the substantial accent which Moscow has been recently giving to its conventional deterrence.

The aim of this chapter is to determine the level of nuclear component in the Russia's Black Sea strategy in the framework of the general purposes Russia is following in the region.

First, we suggest looking at the general principles of the Russian deterrence strategy, in particular, the controversial "escalation for de-escalation", or the use of nuclear weapons at some stage of the conflict to de-escalate it.

It's quite possible to say that if 'escalation for de-escalation' exists then we should look for its evidence not in the "Zapad" military trainings (which 
is a traditional marker of analyzing Russian attitude to the war with the West and recently was mostly focused on simulating the conventional stalemate) but at the Russian naval leg development, its doctrinal as well as procurement dimensions. The navy is the most developing part of the Russian forces (as it is used to be the most underdeveloped for many years) therefore its doctrinal background as well as the procurement cycle is lagging a bit behind the land leg and shows the most recent updates of Russian military posture.

In this connection we would like to analyze the following issues: 1) "the escalation for de-escalation" as a principle in Russian military thought and its perception in the West; 2) the core tendency of the Russian fleet development and its involvement with the famous "March $1^{\text {st" }}$ Russian weapons; 3) the role of Crimea and the Russian Black Sea fleet in Moscow strategic planning.

The escalation for de-escalation strategy and its perception in the West

According to the US Nuclear Posture Review, Russian nuclear strategy calls for the early use of nuclear weapons in the event of a conflict with NATO with the aim to coerce the major adversary to step back in interfering into the regional conflict of Russia with its neighbors. In particular the NPR comments: "It [Moscow] mistakenly assesses that the threat of nuclear escalation or actual first use of nuclear weapons would serve to "de-escalate" a conflict on terms favorable to Russia" (Nuclear Posture Review Final Report, 2018).

On the other hand, in his 2018 Valdai Speech, President Putin declared unequivocally: "Only when we know for certain - and this takes a few seconds to understand - that Russia is being attacked will we deliver a counterstrike... Of course, this amounts to a global catastrophe, but I would like to repeat that we cannot be the initiators of such a catastrophe because we have no provision for a preventive strike" (Заседания дискуссионного клуба Валдай, 2018).

These almost contrary claims have also become the subject of the experts' battles over the meaning of escalation for de-escalation. In particular, Matthew Kroening of Atlantic Council warned that Russia was ready for the early use of nuclear weapons just to force NATO "to sue for peace or risk further, potentially catastrophic, nuclear escalation" (Kroening, 2018). Therefore, the main discussion was concentrated around the idea of preventing Russia from this early use of nuclear weapons.

Yet, a number of experts denied the existence of "escalation for de-escalation" principle in Russian strategy. In particular, Kristen Ven Bruusgaard mentioned the rapidly developing Russian conventional arsenal which, together with the doctrinal statements, showed a certain increase of the nuclear threshold. She also pointed out the rationality of Russian authorities who 
would probably never start nuclear conflict with such a powerful organization as NATO (Ven Bruusgaard, 2017). While Olga Oliker and Andrei Baklitsky referred to the mostly conventional character of "Zapad-2017" military exercise, which usually simulates Russian conflict with the West (Oliker, Baklitskiy, 2018).

On the other hand, none of the experts denied the coercive manner of Russian nuclear behavior, also admitting the fact that at some point during a big conflict, Russians would be likely to use nuclear weapons. The main difference between experts' opinions is likely the time/stage of Russian willingness to use nuclear weapons. Is it supposed to happen at an early stage of the conflict, started by Moscow with the determination to split NATO by attacking some of the former Russian spheres of influence such as Baltic? Or are nuclear weapons still considered to be the last resort when Russians won't be able to contain NATO's attempt to interfere into the Moscow's sphere of influence and, for example to push it out of Crimea?

Such expert discussions were always accompanied by Russian military trainings, proving its validity to each side of the argument. In particular, after conventional "Zapad-2017" the trainings "Vostok-2018" turned out to be the biggest in Moscow military history since 1982. And in 2019 Russia conducted "Grom-2019" which some of the commentators called "the repetition of the global nuclear war" (Гольц, 2019).

With that said, we would like to explore the real meaning of the phenomenon which the West calls "the escalation for de-escalation" in Russian strategy. To make this research successful let us refer to the facts from the history of this term and its basic roots.

The idea of "escalation for de-escalation" was formulated in the beginning of the last decade when on one hand Russia was substantially inferior to the West over conventional weapons and on the other was really concerned not to repeat the destiny of Serbia in 1999.

Here three important things should be mentioned. First declared in the Russian Military Doctrine of 2000 where Moscow stated the possibility of using nuclear weapons in the regional war "under critical circumstances when conventional means proved their inefficiency" (Военная доктрина Российской Федерации, 2000). Deterring conventional conflicts (especially regional wars) with nuclear weapons means that nuclear weapons are regarded as possible means of reaction at this type of conflict. They serve as a main insurance that Russia will neither be defeated nor even engaged in the regional war.

Second, this idea was completed by the concept of predetermined damage, appeared in the document instead of the "unacceptable damage" notion. 
The predetermined damage was defined as the "damage subjectively unacceptable to the enemy as being higher than the advantages the aggressor is waiting to gain from the application of military force" (Военная доктрина Российской Федерации, 2000). This notion is probably not acceptable when it comes to the survival of the state or its closest allies (such as NATO states for the US), but closely fits the idea of regional war waged out of the sphere of the US vital interests. According to the authors, "the aggressor," having received certain damage from nuclear weapons, would step back as a result of cost-benefit analysis. And third, one should not forget about the concept of the limited strategic nuclear strikes, which was developed by the Russian Ministry of Defense in 2003 and, in spite of its absence in the texts of the official Russian doctrines in 2010 and 2014, has never been officially denied (Актуальные задачи, 2003).

Since 2010, Russian Military Doctrine has been trying to connect the use of nuclear weapons with the existence of the state. "In case the emerging conventional conflict puts the existence of the states in jeopardy, the possession of nuclear weapons may lead to the transformation of conventional conflict into nuclear one" (Военная доктрина Российской Федерации 2010). Here the meaning of "existential" looks vague enough: for Russia it may be significantly different from the Western meaning. Clearly, it includes territorial integrity, but probably also the survival of the political regime. It's less clear whether it includes the vital sphere of influence. In any event, it does include defeat in a large-scale (but less than global) conventional war: the defeat of Serbia in 1999 clearly remains the underlying scenario.

The question is whether this threat has real ground or if it's just a coercive tool? Russia always envisioned scenarios of confrontation with NATO as the Alliance aggression over a range of contingencies (including, in no small measure, over Georgia or Ukraine). NATO, in contrast, almost without exception, regarded the threat of nuclear use not as deterrence, but as a tool to prevent the West from interfering with the expansion of Russian influence (Sinovets, 2019).

A big transition point came in 2014. Until then, Russia clearly foresaw limited use of nuclear weapons in less-than-global (regional) conflicts for the purpose of terminating them on favorable conditions, which probably meant status quo ante. In a more fundamental way, it was clearly intended to deter NATO from engaging in any conflicts, which could result in a major defeat of Russia.

In 2014, the new Military Doctrine introduced the notion of conventional deterrence, which has, at a minimum, heightened the nuclear threshold and introduced the possibility that the same category of conflicts could be 
waged and terminated without resort to nuclear weapons. However, the reliance on conventional weapons, while increasing the threshold, is not likely to change the more fundamental choice: either way, conventional strikes are supposed to signal to NATO the seriousness of Moscow's resolve and communicate the risk that if conflict continues, the next step could be the use of nuclear weapons.

At the same time, conventional weapons do not have the same deterrent effect as nuclear. To what extent and under what conditions nuclear weapons still feature in regional conflicts is unknown. Vagueness is likely intentional and is designed to make NATO extra-cautious.

In the 2014 Military Doctrine, the clause of nuclear weapons use was abbreviated to "when the existence of the state is in jeopardy», still not clarifying the character of the threat (Военная доктрина Российской Федерации, 2014). It was published the year Moscow annexed Crimea, started its hybrid war in Donbas, and accelerated military maneuvers at the border with Baltic states. The latter together with the concentration of Russian troops and Russian strategic bombers' multiple provocations in NATO airspace caused strong anxiety in the West. The main concern was whether Russians were going to provoke regional war in Europe where nuclear coercion would provide Moscow with escalation dominance.

Meanwhile, since 2014, Moscow hasn't rushed to ruin the NATO domain, still showing that its primary intention is to keep the West out of the non-NATO former Soviet republics. It looked like Russia was using the principle of "the threat which leaves something to chance", brightly reflected in Russian nuclear strategy. No one knows for sure if and when Russia will be ready to use its nuclear weapons a fortiori most of the weapons Russia currently produces are dual use.

The last document in this domain, "Basic Principles of State Policy of the Russian Federation on Nuclear Deterrence", published in June 2020 seems to confirm the vagueness of Russian deterrence as well as to ensure the West that Moscow 1) will use nuclear weapons in the extreme circumstances; 2) the extreme circumstances is about the existence of the state and its territorial integrity, the clear hint on the annexed Crimea which is codified in Russia defense/deterrence perimeter as fait accompli; 3) the escalation for de-escalation is still possible, but its again presented as extreme situation, which Russia won't be able to manage with conventional weapons; 4)vagueness of the nuclear weapons use' scale, time and place, which also indirectly hints for possible de-escalation scenarios (Basic Principles of State Policy of the Russian Federation on Nuclear Deterrence, 2020).

All things considered, it seems unlikely that the introduction of nuclear deterrence has removed limited use of nuclear weapons in regional conflicts 
from the range of contingencies. If faced with a major defeat in a conventional conflict, Russia is nonetheless likely to cross the threshold.

\section{From the Russian Fleet Development to March $1^{\text {st }}$ weapons}

Today we should derive from the fact that the enlargement of NATO and the development of its military infrastructure near Russian borders - is one of the dangers to the security of our state. That is why we paid and will pay the most significant attention to the technical ... modernization of the Russian Navy (Путин сообщил о модернизации флота из-за угрозы со стороны HATO, 2020).

Traditionally, the Russian fleet has always been inferior to its land forces which could be easily explained by Russia's territory being the largest in the world, while its access to the oceans has never been as direct, for example, as the United States'.

Meanwhile, the last decade has also turned out to be the time of the Russian fleet's rise. This tendency has become especially obvious after the annexation of Crimea and the growth of Russian Black Sea capabilities.

It started from the 2015 Russian Maritime Doctrine, which noted the development of the Black Sea and Azov fleets, pointing out "the accelerated modernization and comprehensive reinforcement of the strategic position of the Russian Federation, while maintaining peace and stability in the region" (Maritime Doctrine of the Russian Federation, 2015).

Still the next document from 2017 "The Fundamentals of the State Policy of the Russian Federation in the Field of Naval Operations for the Period Until 2030" looked much more ambitious. In particular, it emphasized the necessity to maintain "naval capabilities at a level that guarantees the deterrence of aggression against the Russian Federation from the oceans and the seas, and the ability to inflict unacceptable damage on any potential adversary' (The Fundamentals of the State Policy of the Russian Federation, 2017). In general such words as "nuclear and non-nuclear deterrence", "strategic stability" and "unacceptable damage" are the most common for the document, meeting much more frequently than in the Military Doctrine of 2014.

Meanwhile, the most interesting part of this document is its declared readiness to use non-strategic nuclear weapons for de-escalation: "During the escalation of military conflict, the demonstration of readiness and determination to employ non-strategic nuclear weapons capabilities is an effective deterrent" (The Fundamentals of the State Policy of the Russian Federation, 2017). Actually, this document forced even some prominent Russian experts to admit the officially codified "escalation for de-escalation" or preemptive nuclear strike (Стефанович, 2020). 
The interesting passage can also be found in the Deterrence Fundamentals as for the Black Sea region. Among the 'red lines' for the nuclear weapons use, the article $19 \mathrm{C}$ notes the "attack by adversary against critical governmental or military sites of the Russian Federation, disruption of which would undermine nuclear forces response actions" (Basic Principles of State Policy of the Russian Federation on Nuclear Deterrence, 2020). As far as the Black sea fleet may be involved in the "escalation for de-escalation" tasks, we believe that it raises the chances of Russian nuclear involvement in the region. Especially if used when the state territorial integrity (or the Crimea status) is endangered.

In the end, we have an interesting situation where escalation for de-escalation could only be found in the official document, dedicated to the slowest developing leg of the Russian strategic triad.

However, this declaration doesn't lack credibility, firstly because of the rapid modernization of the Russian fleet and the introduction of the newest types of weapons along with the so-called "March $1^{\text {st }}$ weapons". What we mean here is 4 types of the new strategic nuclear weapons introduced by President Putin at his Federal Assembly Speech on March 1, 2018. From the four types of new weapons, two were presented (and mostly tested) for the Russian navy. In particular, it's the "Poseidon" strategic nuclear powered, nuclear armed drone submarine, which former Pentagon official Marc Schneider called, "the most irresponsible nuclear program that Putin's Russia has ever come up with" (Stillwell, 2016). Meanwhile, the mission of "Poseidon" (aimed at causing tsunamis at the US coastline) is still hardly incorporated into the fleet strategic missions, mostly reminiscent of "a Doomsday machine", not really relevant outside of a nuclear war apocalyptic scenario.

The other one, "Kinzhal", a hyper-sonic air launched cruise missile, usually carried and launched by MiG-31K fighter planes, presents a more relevant threat in the framework of the goals announced by the Navy Fundamentals. In particular, it is supposed to be produced in two versions: conventional and nuclear. Referring to Russian missile expert Dmitriy Stefanovich, Russian perception and missions for hypersonic weapons are quite different from the US approach. While Americans are oriented on highly précised conventional strikes with hypersonic weapons, "for Russia, it's the meaning of guaranteed delivery of nuclear weapons at the necessary distance" (Стефанович, 2020). The reason is the eternal fear of Russians that the US missile defense (in this case European deployed) will somehow undermine Russian strategic deterrence capabilities. Therefore the primary mission of "Kinzhal" (also having in mind the high material value of this missile as well as the availability of supporting conventional deterrence with much cheaper missiles) may probably be a nuclear one. 
Also, one of the future "super-weapons" models, assigned to the Russian navy, will be the hypersonic sea-based missile "Tsirkon," which is going to be introduced into the Russian navy in 2022 and will have a range 500$1000 \mathrm{~km}$. The "Tsirkon" is planned as an antiaircraft weapon, used by warships as well as submarines and launched from most of the carriers, equipped with "Kalibr" missiles (Птичкин, 2019).

Speaking about Russian navy weapons developed during the last decade, serious concern is caused by the SLCMs "Kalibr", successfully tested by Moscow in its military operations in Syria. It is not attributed to the new "super weapons", however it is considered to be one of the most effective medium range cruise missiles with a range up to $2500 \mathrm{~km}$. According to some Russian experts, the main trend of the current Russian navy is to equip most of the submarines (28 atomic and 23 diesel ones) with "Kalibres", which should significantly increase the potential role of the navy to inflict the unacceptable damage to the enemy (Sinovets, 2018).

The role of the Russian Black Sea fleet in Moscow strategic planning It is well known that after the annexation of Crimea from Ukraine, Russia has turned the peninsula into one of the most militarized points of the region: the bastion of Russian glory" as well as the fortress of Russian power projected in the region.

Since 2015, the armed potential of the Russian Black Sea Fleet is growing.

First, there is the offensive potential. No doubts that Russian strategic submarines belongs to its Northern and Pacific fleets, while the navy of the other two (Baltic and Black Sea Fleets) consist only of the sub-strategic units. Here it's worth keeping in mind that non-strategic nuclear forces were specially noticed by the "Navy Fundamentals" when it comes to escalating military conflicts.

Meanwhile, the Russian Black Sea Fleet includes Admiral Grigorovich guided missile class frigates (project 11356) and six "Varshavyanka" 636.3 class submarines, both equipped with torpedoes, cruise and anti-ship missiles (Petersen, 2019). However, there are no doubts that both frigates of this class, as well as 636.3 submarines, are also equipped with "Kalibr" missiles with land-attack, anti-ship, and antisubmarine warfare versions. "Kalibr" exists in both nuclear and in conventional versions and when it is deployed in the Black Sea, it is capable of targeting most of the European NATO states.

To this picture can be added the cruiser "Moskva", produced in the $1970^{\text {th }}$ as the antiaircraft force, today carrying anti-ship "Vulkan" missiles with the range of 700-100 km and also able of carrying S-300 air defense missiles and anti-submarine torpedoes. Also 41 Brigade, consist of ten Taran- 
tul-class corvettes with anti-ship P-270 Moskit missiles, as well as two P-270armed Dergach-class hovercraft-corvettes, a Buyan-M corvette mounting eight Kalibur cruise missiles, and two older Nanuchka-III corvettes carrying out supportive function to the above mentioned armor (Robin, 2018).

Second, it's the defensive weapons. In particular, Moscow deployed four battalions of S-400 missile systems (one was added after the Russian-Ukrainian incident at the Caspian Sea) and well as "Bastion" systems to cover virtually all of the Black Sea. The "Bastion" system "Oniks-800 anti-ship ramjet powered supersonic cruise missiles having a range of 400 $\mathrm{km}$ are able to make Russia feel safe enough at the Northern part of the Black Sea. Also S-300 and "Pantsir-S1" point defense systems were deployed there. Dmitriy Gorenburg points out that due to the deployment of S-400 and Bastion systems Russia managed to establish an anti-access/area-denial zone (A2AD) expanding across almost all of the Black Sea. This situation provides Russians with the capability 'to inhibit military movement into the Black Sea and deny freedom of action to an opponent if it does make it into the theater' (Gorenburg, 2018).

All in all, the Russian Black Sea Fleet does not have too many warships, but the appropriate combination of offensive and defensive weapons provides the military with the capabilities to perform tactical operations in the spirit described in the Navy Fundamentals de-escalatory actions.

The military trainings Russia was conducting on the Black Sea has shown that not only Kalibr missiles, but also strategic bombers and some of the newest weapons such as "Kinzhal" missiles maneuvers was practiced on the Black Sea. The Russian joint missile-firing exercises on the Black Sea and the Northern fleets with launches from water, air, and coast are considered unprecedented in scale. Conducted in the south and southwest of occupied Crimea, the joint exercises involved forty ships, a submarine, more than forty aircrafts and helicopters (Klimenko, 2020).

The 2020 schedule of Russian military exercises hasn't left any doubts in the intentions of Moscow to strengthen this flank. In particular, large scale strategic Command Post Exercises "Caucasus-2020" are planned for the Southern Military District of Russia for the two first months of autumn. Aimed at improving coordination of the joint forces performing the largescale military operation at the Southern and South-Western military theaters, it is supposed to involve about 100 battleships and auxiliary ships from the Black Sea and Caspian Flotilla (Klimenko, 2020).

\section{Conclusion and scenarios for the Black Sea Fleet}

The current amount and the capabilities of the Black Sea fleet is not constructed in a way to wage strategic war. However, it is enough for sup- 
porting Russian coercive behavior and even for performing tactical de-escalatory operations on sufficient level. Also, the main aim of the Russian Black Sea Fleet is often described as "power projection".

Therefore the main mission of the Russian Black Sea Fleet can be implied in interconnected domains.

Scenario 1. Russia uses the Black sea Fleet for the power projection/ coercion in the region.

Many experts agree that Russia will keep using the Black Sea as a platform for expanding its influence on neighboring regions, including the Balkans, the Middle East, and the Mediterranean countries. We speak primarily about the military influence.

With the increasing of the number of ships in the Black Sea fleet, it is gradually becoming the main base for performing military operations in Syria. In spite of the two military bases Russia has in Syria, most of its significant military operations are performed with the participation of the Black Sea fleet and its warships equipped with the "Kalibr" SLCMs, brightly tested by Moscow in the Syrian conflict.

The other function is the increasing power projection in the Mediterranean where Russia identifies many threats not only for its homeland security, but also for its influence over the Syrian conflict. The other regions of future responsibility for the Black Sea Fleet are mentioned by Admiral Vitko, in particular 'the waters of the Red Sea, Aden and Persian Gulf as well as the western part of the Arabian Sea, which today are considered the responsibility of the Pacific Fleet (Витко, 2017)'. According to the expert analysis, the regional power projection task is quite possible to reach even 'with a small number of frigates, the fleet will present a potential threat to other naval forces in the region, even U.S. carrier strike groups' (Gorenburg, 2018). The large number of the surface battleships required for this mission, the situation, is clearly reflected in the current quality content of the Russian Black Sea fleet today. Also, considering the dual use character of the March $1^{\text {st }}$ weapons, it can be foreseen that for the Black Sea they significantly strengthen the A2/ AD strategy for the Black Sea.

In this connection, the main task of the Russian fleet is practicing successful $\mathrm{A} 2 / \mathrm{AD}$, based on mostly conventional deterrence, still admitting the low level nuclear operations, aimed to strengthen deterrence stability. This connection of the conventional and nuclear options forms the backbone of Russian general deterrence posture considering permanent coordination of the Black Sea and the Northern Fleet military trainings.

The creation of the A2/AD area in the Black Sea also makes a strong platform for Russia's coercive behavior, manipulating with the threat to deny 
(or limit substantially) NATO's military trainings in the region, which at the end brings us to the old concern of Moscow turning the Black Sea into the Russian Lake.

Scenario 2. Black Sea Fleet as a means of deterrence and defense of $\underline{\text { NATO }}$

First, deterring NATO from the military expansion to the South-East and also neutralizing new military infrastructure can threaten Russia's deterrent capabilities at the Southern Flank. In particular, we know that the enlargement of NATO to the East as well as building up the European Missile Defense sites in Europe are attributed to the "dangers" for Russian security in the official "Military Doctrine" from 2014. Also, the deployment of the Aegis Ashore site in Romania (introduced in 2016) was severely criticized by Russian officials. In particular, president Putin declared that the system being deployed in Romania was not defensive, but part of the U.S. strategic nuclear capability. Therefore, he mentioned in May 2016 that Moscow "will be forced to think about neutralizing the emerging threats to Russia's security" (Putin: Russia will consider tackling NATO missile defense threat, 2016). There were a couple of concerns. The first and the basic was the theoretical and non-existent yet possibility of the SM-3 interceptors to take off Russian missiles in the future which was still considered as a potential danger. The second concern, appeared later was the supposition of the Russian military that the SM-3 Aegis Ashore system could be also used for launching "Tomahawk" cruise missiles. The latter fact was denied by the Americans while the INF treaty was still on, however after the withdrawal in August 2019 the US successfully tested cruise missile from the SM-3 launcher. This situation potentially makes Aegis Ashore site in Romania not only the point of future concern, but also is regarded by Russians as the potential offensive military infrastructure of the Alliance, especially in light of the US' recent decision to produce intermediate-range missiles to deploy in Europe. In a way, the current composition of the Black Sea Fleet reflects this kind of need in a best way. In particular, before the Crimea annexation, Russians could probably only target Aegis Ashore by their "Kalibr" SLCMs, however the taking over of the Ukrainian territory made reaching this goal much easier and with the wider range of ammunitions.

Second, the annexation of Crimea made the Black sea fleet much more strategic for Russia in many ways. Let's remember that in the 2020 "Basic Principles of State Policy of the Russian Federation on Nuclear Deterrence"," Russia officially declared its territorial integrity among the main objects its nuclear deterrence is to stand for. This immediately brings up Crimea, which could be a reason for de-escalatory use of nuclear weapons in case Russian 
conventional deterrence won't be effective enough to keep the West from the direct military Western intervention.

Summing up, the evaluation of the strategic dimension of the Russian Black Sea Fleet shows that the primary focus was on the creation of the A2/ $\mathrm{AD}$, which gives Russia: a) steady ground to practice coercion in the region, partially diminishing the role of the Alliance in the region; b) strengthens deterrence at the Southern flank, which is reached by the combination of the deployment of the modern dual-use weapons, supported by the maritime doctrine permitting tactical de-escalatory actions.

\section{References}

1. Актуальные задачи развития Вооруженных сил Российской Федерации. (2003). Москва: Министерство обороны РФ.

2. Витко, А. (2017). Черноморский флот: фактор расширения боевых возможностей в зоне ответственности. Взято 3: http://milportal.ru/chernomorskijflot-faktor-rasshireniya-boevyh-vozmozhnostej-v-zone-otvetstvennosti/

3. Военная доктрина Российской Федерации. (2010). President of Russia. Взято 3: http://news.kremlin.ru/ref_notes/461

4. Военная доктрина Российской Федерации. (2014) President of Russia. Взято 3: http://static.kremlin.ru/media/events/files/41d527556bec8deb3530. pdf

5. Военная доктрина Российской Федерации. (2000). President of Russia. Взято 3: http://www.ng.ru/politics/2000-04-22/5_doktrina.html

6. Гольц, А. (2019). Репетищия катастрофы. Взято 3: HTTPS://WWW. EJ2020.RU/?A=NOTE\&ID $=34300$

7. Стефанович Д. (2019). Военные действия вновь вернулись в инструментарий великих держав. (2020). Бизнес Газета. Взято 3: https://www. business-gazeta.ru/article/458879

8. Заседания дискуссионного клуба Валдай. (2018). President of Russia. Взято 3: http://kremlin.ru/events/president/news/58848

9. Птичкин, С. (2019). Гиперзвук на подлете. Взято з: https://rg.ru/2019/09/19/ chto-predstavliaet-soboj-giperzvukovaia-raketa-cirkon.html

10. Путин сообщил о модернизации флота из-за угрозы со стороны НАТО. (2019). RBC.ru. Взято 3: https://www.rbc.ru/politics/03/12/2019/5de65ffa9a $7947068 \mathrm{~d} 52 \mathrm{c} 0 \mathrm{~d} 0$

11. Basic Principles of State Policy of the Russian Federation on Nuclear Deterrence. (2020). The Ministry of Foreign Affairs of Russian Federation. Retrieved from: https://www.mid.ru/en/foreign_policy/international_safety/disarmament/-/asset_publisher/rp0fiUBmANaH/content/id/4152094

12. Gorenburg, D. (2018). Is the New Russian Black Sea Fleet Coming? Or is it here? War on the rocks. Retrieved from: https://warontherocks.com/2018/07/ is-a-new-russian-black-sea-fleet-coming-or-is-it-here/

13. Joint Exercises of Northern and Black Sea fleets. (2020). President of Russia. Retrieved from: http://en.kremlin.ru/events/president/news/62556 
14. Klymenko, A. (2020). Naval Warfare Scenarios for 2020. UA: Ukraine Analytica, 1 (19), 27.

15. Kroening, M. (2018). A Strategy for Deterring Russian Nuclear De-Escalation Strikes. Atlantic Council. Retrieved from: https://www.atlanticcouncil. org/wp-content/uploads/2018/04/Nuclear_Strategy WEB.pdf

16. Maritime Doctrine of the Russian Federation. (2015). Russia's Maritime Studies Institute, US Naval War College. Retrieved from: https://dnnlgwick. blob.core.windows.net/portals/0/NWCDepartments/Russia\%20Maritime\%20 Studies\%20Institute/Maritime\%20Doctrine\%20TransENGrus FINAL.pd$\mathrm{f}$ ? $\mathrm{sr}=\mathrm{b} \& \mathrm{si}=$ DNNFileManagerPolicy\&sig=fqZgUUVRVRrKmSFNMOj\%2FNaRNawUoRdhdvpFJj7\%2FpAkM\%3D

17. Nuclear Posture Review Final Report. (2018). U.S. Department of Defense. Retrieved from: https://media.defense.gov/2018/Feb/02/2001872886/-1/1/1/2018-NUCLEAR-POSTURE-REVIEW-FINAL-REPORT.PDF

18. Oliker, O., \& Baklitskiy, A. (2018). The Nuclear Posture Review and Russian De-Escalation: A Dangerous Solution to an Non-Existent Problem. War on the Rocks. Retrieved from: https://warontherocks.com/2018/02/nuclear-posture-review-russian-de-escalation-dangerous-solution-nonexistent-problem/

19. Petersen, M. (2019). The Naval Power Shift in the Black Sea. War on the Rocks. Retrieved from: https://warontherocks.com/2019/01/the-naval-powershift-in-the-black-sea/

20. Putin: Russia will consider tackling NATO missile defense threat (2016). Retrieved from: https://www.rt.com/news/342915-putin-nato-threat-missiles/

21. Roblin, S. (2018). Introducing Russia's 5 Deadliest Warships in the Black Sea. National Interest. Retrieved from: https://nationalinterest.org/blog/buzz/ introducing-russias-5-deadliest-warships-black-sea-37677

22. Sinovets, P. (2018). How Russia's Nuclear Buildup Offers a Good Opportunity for Renewed Arms Control Dialogue. PONARS Eurasia. Retrieved from: http://www.ponarseurasia.org/memo/how-russias-nuclear-buildup-offers-good-opportunity-renewed-arms-control-dialogue

23. Sinovets, P. (2019). Escalation for De-Escalation? Hazy Nuclear-Weapon "Red Lines" Generate Russian Advantages. PONARS Eurasia. Retrieved from: http://www.ponarseurasia.org/memo/escalation-de-escalation-hazy-nuclear-weapon-red-lines-generate-russian-advantages

24. Stillwell, B. (2016). Russia's powerful new submarine nuke drone is a coastal killer. Retrieved from: https://www.wearethemighty.com/articles/russian-superweapon-is-a-submarine-nuke-delivery-drone

25. The Fundamentals of the State Policy of the Russian Federation in the Field of Naval Operations for the Period until 2030. (2017). Russia's Maritime Studies Institute, US Naval War College. Retrieved from: https://dnnlgwick. blob.core.windows.net/portals/0/NWCDepartments/Russia\%20Maritime\%20 Studies\%20Institute/RMSI_RusNavyFundamentalsENG_FINAL\%20(1). pdf? sr=b\&si=DNNFileManagerPolicy\&sig=fjFDEgWhpd1ING\%2FnmGQXqaH5\%2FDEujDU76EnksAB\%2B1A0\%3D

26. Ven Buusgaard, K. (2018). The Myth of Russia's Lowered Nuclear Threshold. War on the Rocks. Retrieved from: https://warontherocks.com/2017/09/themyth-of-russias-lowered-nuclear-threshold/ 


\section{CHAPTER 5 \\ THE EU'S POLICY TOWARDS THE BLACK SEA REGION: CLASH OF INTERESTS, RESPONSIBILITY AND THREATS}

(Iryna Maksymenko)

\section{Introduction}

Since ancient times, the Black Sea has acted as a kind of hub, where the interests and paths of big and small actors intersect. The spread of culture, international trade, migration flows and the struggle for strategic control over the region - these and other factors have for centuries maintained the importance of the Black Sea Region (BSR) for Europe. However, under the rule of the Ottoman and later Russian Empires, which turned it into an inland sea, the BSR acquired a peripheral status in the world and European politics. The end of the Cold War's bloc confrontation and the collapse of the Soviet Union opened the way to the region for the European Union (EU) and the way to a united Europe for countries of the Black Sea.

In the 1990s, the EU became one of the key forces influencing the region's transformation. This transformation derived mainly from the following factors. Firstly, the European intentions for the integration of the post-communist BSR countries have created the conditions for the building of a system of relations between the region and the European Union. Secondly, as the configuration of the international system changed, the EU declared its readiness to take responsibility for the peace and unification of a divided Europe and for the democratization and development of its peoples. In this context, the potential of the Black Sea region in the field of transport-transit and energy communication was considered to be an important aspect of the European economy and trade. Thirdly, the EU's attention to the region was and is triggered by the very existence of negative regional factors which could have consequences for the security of the entirety of Europe (such factors include conflicts, economic crises, political instability, and organized crime). The geographical proximity and bilateral cooperation between the EU and individual countries in the region, which has been developing dynamically, has gradually created numerous channels through which waves of instability and danger reach Europe. Finally, with the integration of Bulgaria and Romania, the European Union is becoming one of the most important economic and political actors in the Black Sea region in terms of a set of political, economic, and strategic criteria. Two of the Black Sea countries are members of the Union; other members, in particular Greece, Poland and the Baltic States, 
are interested in strengthening the EU's role in the Greater Black Sea region. In addition, the EU maintains bilateral ties with all countries in the region, including Ukraine, Moldova and Georgia, which have all signed Association and Free Trade Agreements. Turkey and the EU are linked by the current Customs Union and membership negotiations, and Russia is recognized as an EU strategic partner. The relationship between the EU and the region is strengthened due to the fact that the EU is the largest trade and investment partner for all of the BSR, and it receives more than $34 \%$ of its natural gas and oil from the region (mainly from Russia and Azerbaijan). According to Eurostat, in 2018 the EU's share of Moldova's trade balance was 50\% (4.7 billion Euros), Georgia's was 30\% (2.8 billion Euros), Ukraine's was 40\% (40.1 billion Euros), Turkey's was 43\% (153.4 billion Euros), and Russia's was about 43\% (253.6 billion Euros). The EU is the largest investment partner for Ukraine, Turkey, and Russia: in 2017, Ukraine received investments from the EU in the amount of 12.9 billion Euros, Turkey received 88.2 billion Euros, and Russia received 299.7 billion Euros.

But can EU be considered as a genuine actor in the regional system of international relations? Does it really demonstrate a strategic approach to the region, taking responsibility for the development of the region as an integrated part of the European continent, as stated in the EU Black Sea Strategy? In order to answer these questions, it is worth recalling how the EU's policy towards the Black Sea region was formed highlighting what its interests were and what factors can determine the effectiveness of EU policy, given the current situation in the region.

\section{Development of EU approaches to the Black Sea region}

The first stage of the EU policy's build-up towards the BSR can be identified with the signing of Partnership and Cooperation Agreements with the countries formed after the collapse of the USSR: Belarus, Ukraine, Moldova, Russia, Georgia, Armenia, and Azerbaijan, throughout the period of 19941999. These bilateral documents laid the foundation for further relations between the European Union and each country. They also included a narrative of the EU's intention to promote regional cooperation between neighbouring countries for the development and stability of the region, including initiatives aimed at deepening cooperation and mutual trust between independent neighbouring countries.

The adoption of the Communication on Regional Cooperation in the Black Sea Region in 1997, in which the EU for the first time officially declared the importance of the BSR for a united Europe, can be considered to be the next step in the build-up of the EU's policy. The document mentioned that, in recognizing the growing strategic importance of the Black Sea for 
the European Union, the Commission expressed its "intention to develop a new strategy for regional cooperation" aimed at promoting cooperation in transport, energy, trade, environmentally sustainable development, justice and home affairs. The next step in this direction occurred when the European Parliament reviewed the possibility of creating a "European Union - Black Sea" community. Later on, however, the BSR would be hardly mentioned.

Even in the European Security Strategy of 2003, the BSR was mentioned only in the context of implementing the EU's security policy (in order to build security in Europe's neighbouring regions). The importance of building a circle of stable countries to the east of the EU by stimulating economic and political cooperation of the eastern neighbours was only briefly mentioned. A similar view is enshrined in the 2003 Communication "Wider Europe - Neighbourhood: A New Framework for Relations with our Eastern and Southern Neighbours", which called for the formation of a 'circle of friends' along the EU's southern and eastern borders, united by common values, open market relations and borders, as well as strengthening cooperation in key areas like transport, energy, the environment, and conflict prevention.

Despite its 1997 declaration of intentions, the EU failed to pay attention to the Black Sea vector, a failure which was emphasized at the European Parliament in January 2008: "Parliament is not satisfied with the progress made since...1997 and calls for a genuine regional dimension on this area, with concrete proposals to promote regional cooperation" and the creation of a free trade area in the region (MEPs speak).

The reasons for the low assessment of the EU policy towards the BSR at that time lie mainly in the fact that the EU, by focusing on the processes of internal transformation of the EU itself, solving the dilemma of "deepening vs. enlargement", and looking for its own place in the post-bipolar world, was unable to look far beyond the then-existing borders of the union. Conflicting views on the strategic importance of the region for Europe did not contribute to the rapid development of a strategic approach that could reflect the common interest and political will of all EU members (which were, back then, purely Western European countries). Thus, before the tragic events of September 11, 2001, the Black Sea remained, according to R. Asmus and B. Jackson, a "civilizational black hole" in the Western historical consciousness (Asmus, \& Jackson, 2004). The potential importance of the region as a transit area for energy resources from the Caspian Sea, the threat of unresolved conflicts in Moldova and the South Caucasus, as well as the limited markets of these countries, according to B. Coppieters, were, in the eyes of the EU, inferior to Balkan problems (Coppieters, 2003, p. 164). In addition, at that time the EU had just recognized the need to transform the European Union 
into a stabilizing factor and model itself for a new, multipolar world (Laeken Declaration, 2002). As a result, it was really too early to expect quick results.

The situation started changing after 2004. First, thanks to the enlargements of 2004 and 2007, an Eastern European lobby was formed by Poland, Romania, and Bulgaria. Second, the democratic and pro-European revolutions in Georgia and Ukraine were seen as challenges to the EU's fundamental principles; this in turn required official Brussels to respond accordingly. Third, the expansion of the EU's economic and energy interests towards the Caspian region and the Middle East has strengthened the importance of the regions for energy transit. Finally, given the terrorist threat, the BSR acted as both a buffer and a partner for the EU and NATO in countering the spread of the Islamist threat. Therefore, under the pressure of these factors, the Black Sea vector finally appeared on the agenda of European policy.

The first achievement was the adoption of the document titled "Black Sea Synergy - a new regional cooperation initiative" (2008), which became both a declaration of a common European vision for the region and stated the EU's position on regional processes and main principles of its activities in the region while taking into account common interests. This was an important stage in the formation of EU policy towards the region, which, according to A. Schockenhoff (a member of the German Bundestag), had to serve "as a catalyst and anchor for regional cooperation between countries" in the region (Schockenhoff, 2007, p. 4). The program' duality was due to the fact that, on the one hand, it identified key areas for strengthening regional cooperation; on the other, it tried to stimulate reforms in the region's political and economic spheres, maintain stability and promote growth, implement projects that need practical efforts in the region and, if it had been possible, to create an encouraging atmosphere for resolving conflicts in the region.

Even at this point, European countries did not make this region a priority, nor did they set strategic goals. Calls from the most concerned countries, especially Romania, Bulgaria, Greece, to pay more attention to the 'new neighbour' - the Black Sea Region - and to develop a coherent and more coordinated EU policy were not heard.

Dissatisfaction of the Black Sea's EU member states with the "rather limited results" of the Black Sea Synergy and the "lack of sufficient progress and non-compliance with expectations" resulted in the adoption of the European Parliament's resolution of 20 January 2011 on an EU Strategy for the Black Sea in 2011 (Los Fayos, 2013, p. 4-5). The document was a response not only to dissatisfaction with the results of the Black Sea Synergy, but also to the new geopolitical situation in the context of the low efficiency of the European Neighbourhood Partnership (ENP) and Eastern Partnership (EaP). 
The European Parliament called for the development of an "integrated EU strategy for the Black Sea", which, for the first time since 2007, has become a European inland sea and the EU's area of responsibility for peace, democracy, security, stability, regional cooperation and sustainable prosperity. Secondly, the Sea is now a bridge connecting Europe with the Caspian Sea, Central Asia and the Middle East (and later, potentially with South-East Asia and China), and is characterized not only by close ties and great potential, but also by contradictions and rivalries. These contradictions and rivalries in turn pose new challenges to the EU's foreign and security policies. Thus, the Strategy clearly stated that it is essential to strengthen the EU's political presence in the region.

One such challenge was the aftermath of the Arab Spring, which involved the Southern Mediterranean and Syria. The political crises in these countries, which have been accompanied by mass protests and escalated into civil wars in Syria and Libya, have clearly demonstrated the ineffectiveness of the EU's ENP-based regional policy. Analysts pointed to the potential possibility of spreading the socio-political crisis to the countries of the South Caucasus and the Caspian region (and therefore increasing separatist sentiment there), exacerbating existing contradictions and conflicts, the emergence of new centres of confrontation and more. The destabilization of the Mediterranean, and the mass uncontrolled migration from the Middle East to the EU have sparked a new wave of discussions about the importance of the Black Sea Region in the security dimension. As a result, the EU has revised the ENP and the EaP initiatives, increased funding for programs and introduced a more differential approach to policy makers.

The most powerful challenge for the EU's regional policy was the annexation of Crimea and the Russian Federation's further policy of establishing full control over regional processes by increasing its military presence. The rapid militarization of the Crimean Peninsula and the increase in the contingent of the Russian Navy in the Black Sea have significantly changed the balance of power, reduced the already low level of confidence and exacerbated threats to the security system in Europe.

The EU's response to developments in the region is reflected in the Report on the strategic military situation in the Black Sea Basin following the illegal annexation of Crimea by Russia (May 2015), in which the European Union acknowledged negative changes in the BSR due to Russia's actions; in particular, their exertion of pressure on the eastern borders of the EU, namely Romania, Poland, and the Baltic countries. This increase risks and threatens the entire Black Sea Region, and has already hampered cooperation in important areas like border management and migration control, human trafficking, 
and the fight against organized crime. The EU therefore called for a revision of the basic documents (European Security Strategy, European Maritime Security Strategy, EU Black Sea Strategy, and the ENP) in order to develop a "bold and results-oriented approach, especially in the areas of economy, defence and security, internal EU strengthening, renewal and improving existing instruments, as well as strengthening the Union's response capacity to developments in the neighbouring region" (Report, 2015, p. 7). However, EU policy in the region was based on the Black Sea Synergy, which at the time "[was] practically on hold" (Report, 2015, p. 9).

Today, the EU's position on the direct interest of both countries in the region and the EU's position in a "stable, secure, sustainable and prosperous Black Sea region", and thus the EU's constructive role and responsibility for developing the Black Sea basin, has not changed (Black Sea, 2019, p. 15). However, there has been no radical change in the EU's approach to the BSR. The Black Sea vector of EU policy is still inclusive and is based on a set of internal EU strategies and documents, bilateral agreements with countries in the region, regional initiatives, and EU programs and instruments, all aimed mainly at pursuing the EU's own interests, which can be grouped as follows:

1. Democratic development, the rule of law and political stability as important preconditions for security and stability in the region. The strengthening of mutual trust and the peaceful resolution of conflicts, implemented through the EaP, the Conference of Regional and Local Authorities of the East; EURONEST Parliamentary Assembly, European Neighbourhood and Partnership Instrument (ENPI).

2. Sustainable economic development as a tool for the convergence of various economic regimes in the region, improving the investment climate and creating additional mechanisms for regional cooperation with the prospect of further free trade with the Black Sea countries. This direction is mainly implemented through the EU's bilateral trade and economic relations with the BSR, the EU-Turkey Customs Union and separate FTAs between the EU and Ukraine, Moldova, and Georgia in the framework of the Association Agreements, as well as at the EU-BSEC level. Considerable attention is also paid to cross-border cooperation projects under the ENPI and the EU Strategy for the Danube Region in 2010, which was aimed at stimulating the development of border areas, good border management and tourism development, while also taking into account the rich regional cultural and ethnic diversity.

3. Energy security is an important area for the EU, which implements a number of projects for the modernization and development of energy infrastructure (examples include the Azerbaijan-Georgia-Romania Interconnector (AGRI), Bulgaria-Romania-Hungary-Austria (BRUA), and the Slova- 
kia-Hungary-Romania-Bulgaria "Eastring"; projects involving Ukraine and Romania are discussed as well, in particular the Tranzit and Isakcha-Negru Vode and Tranzit II Orlivka-Isakcha, which will connect the Black Sea and Greece by gas pipelines after modernization). Likewise, the diversification of energy supplies from the Caspian region and Central Asia under the INOGATE program and the construction of LNG-terminals all work toward the implementation of a transparent and equal energy policy within the Energy Union.

4. Transport and communication corridors are an important element of the development of a modern economy. These are supported by the EU under the TRACECA and Trans-European Transport Networks (TEN-T) programs, trans-European transport corridors, especially № 4, 7, 8, 9, and in the framework of the EU Integrated Maritime Policy 2007 projects, the EU Transport Strategy to 2050 and the EU Strategy for the Danube Region, which is considered the EU's gateway to the Black Sea, the South Caucasus and Central Asia. In particular, the BSR is playing the role of a bridge in the field of maritime transport in the Joint Communication Connecting Europe and Asia - building blocks for an EU Strategy (2018) (Black Sea, 2019, p. 13).

5. Crisis prevention and conflict resolution and the strengthening of the capacity of the BSR to combat organized crime is also one of the priorities of the EU in the BSR. In line with its own nature, the EU is focusing its efforts on reforming the security sector and on gradually transforming the conflict environment through economic and social communication, the opening of special missions in Moldova (EUBAM), Georgia (EUJUST Themis and EUMM), Ukraine (EUAM), and the providing of advisory and technical assistance in the reformation of the legislative system and the security sector. The EU has also acted through Eastern Partnership instruments such as the ENPI Joint Operational Programs, in particular, the Black Sea Basin.

The main problems and challenges of $E U$ policy implementation in the BSR

Taken together, the previously mentioned EU initiatives, projects, and instruments on the BSR are aimed at transforming the nature of regional relations from a region of competition into a space of cooperation. In some ways, it can be said that the EU has tried to implement its own formula for building a "peace through an integration project" (Tocci, 2011), in which countries with different levels of development and interests, with common, albeit competing interests, can overcome contradictions and unite for a better mutual future. But to what extent has the EU's Black Sea policy reflected the interests of a united Europe and the countries of the region? Has it been able to achieve 
the goals set out in the projects and strategies, to combine commonalities and differences for common peace and development?

The answer lies in the balance of weaknesses and strengths of EU policy towards the BSR, taking into account objective and subjective factors.

The EU's policy was in principle based on supporting reforms in the $\mathrm{ENP}$ and EaP countries in order to gradually align the regulatory systems of international cooperation and the economic performances of partner countries, which should in turn promote equal participation in regional projects. Other EU initiatives and instruments were aimed at practically supporting the development and improvement of coordination of regional processes in close cooperation with EU institutions and member states. Under the conditions of the ENP, the EaP and other projects objectives' achievements in combination with the Black Sea Synergy, the expectation was the achievement of effective multilateral cooperation which would likewise be expected to address regional challenges and threats. This in general corresponded to the declared interests of all countries in the region.

However, the real interests of individual states such as Russia and Turkey, which viewed the EU as a competitor to their regional power status and even as a threat to national interests, in the words of D. Triantaphyllou, set limitations of the EU's "transforming power" (Triantaphyllou, 2014, p. 287). Indeed, the BSR is a region that does not have a clearly defined regional identity; its members differ by political culture, military potential, level of economic development, foreign policy, and domestic interests. Such divergence of interests has created a number of parallel processes in the region: "integration, regional cooperation (or lack of it) and political blocking" (Тріандафіллу, 2011, p. 48). Indeed, integration with the EU has had a positive effect on the socio-cultural ties of countries which may have a common but complex history. In addition, it introduced further opportunities for another process: regional cooperation, the dynamics of which did not meet the capabilities and needs of the region. At the same time, Russian integration projects - such as the CIS and the CSTO - have come into conflict with European structures, especially NATO, which, according to Russian experts, are posing a threat to Russia's national interests (Глазова, 2012; Заквасин, \& Комарова, 2020).

As to regional cooperation, none of the structures or initiatives of the Black Sea countries - BSEC, ODER-GUAM, BLACKSEAFOR or Black Sea Harmony - have become an effective tool for economic development and multilateral cooperation. The lack of a real basis has led to the emergence of rather formal associations in the region that are unable to achieve significant results. Not surprisingly, 2014 was a starting point for regional cooperation decline. The EU particularly noted that "regional security initiatives [such as] 
the BLACKSEAFOR and the Black Sea Harmony are currently paralyzed" (Report, 2015, p. 7). Even the BSEC, which was one of the most promising platforms for regional dialogue, has fallen into lethargy due to the region's crisis of confidence (Гончар, Мартынюк, \& Ковалева, 2020). Currently, the implementation of the Black Sea Ring transport project has been suspended, and the way forward for the implementation of marine infrastructure and highway development projects does not seem clear. Deputy Prime Minister, Minister of Economic Development and Trade Stepan Kubiv posed a question dealing with just this at the BSEC summit (May 2017), asking both how the road to implementation can be paved through occupied territories and what should be done with the occupied ports. (Віце-прем'єр України, 2017). In this regard, it is important to take into account the following facts: in response to S. Kubiv's words, Russian representatives stated that the project is delayed by the inconsistency of the route between Ukraine, Moldova and Romania (Борьба за мир, 2017). However, the relevant document was signed by the ministers of these countries in April 2014. It states that the parties have identified the following two directions of the Black Sea route: from Odesa to Bucharest via Reni-Giurgiulesti-Galati and from Odesa to Bucharest via Chisinau-Ungheni (The Black Sea Ring, 2014). As of the beginning of the BSEC summit in Istanbul in May 2017, the project participants were already at various stages of implementation of their share of the Black Sea ring road (Black sea countries, 2016).

Another factor that has a direct impact on the limited success of the $\mathrm{EU}$ in the region lies in EU documents. And it is not only the number of such documents on the BSR, but also the fact that declarations, resolutions, and strategies (among others) are all issued by various EU institutions. The decisions reflected in them are influenced by the preferences of those countries that at one time or another chair these European structures. Y. Tsantoulis emphasized that the task of strengthening the role of the EU in solving the Black Sea's "complicated geopolitical jigsaw puzzle" was related to marginal interest (Tsantoulis, 2009, p. 253). This was also pointed out by Triantaphyllou: the haste with which the EU adopted the ENP, the Black Sea Synergy and the EaP, "did not always help the EU to develop a clear approach to the Black Sea region, as the following policy seems to be a consequence of the foreign policy prerogatives of individual participating countries, rather than part of a unified approach to the region" (Тріандафіллу, 2011, p. 49). Indeed, the efforts of some EU member states (mainly France, Germany, Italy, Hungary, the Czech Republic) to avoid aggravating relations with Russia due to close trade and economic ties or energy dependence have led to the freezing of European and Euro-Atlantic integration processes in Ukraine, Moldova, and 
Georgia, (all of which are of course Black Sea countries). This was also found in the long-term distancing of the EU from active involvement in the settlement of a number of long-lasting separatist conflicts of an ethnic, strategic and terroristic nature, which had the effect of turning the BSR into a "security parcel of paramount importance" (Kiфy, 2011, p. 42-43). This also did not exactly help to shape the EU's image as an effective guarantor of security and peace in the region.

It should be noted that the main stages of the EU's policy toward the Black Sea are related to external processes: terrorist attacks on the United States, Great Britain and Spain, the Russian-Ukrainian gas conflict in 2006, the Russian-Georgian war in 2008, etc. It has strengthened the EU's attention to the security and stability of the BSR, its readiness to take responsibility for preventing the emergence of new dividing lines, the spread of conflict, and its support of sustainable developments for peace and prosperity. These processes have also increased the concentration of EU countries on internal processes and strengthening internal security. The lack of a convincing justification for a more active role of the EU in the BSR, a role which would be attractive enough and understandable for both the elites and the public in the remote members of the Union, did not leave resources and political will to form either a strategic approach or an institutional modus operandi. K. Weaver and $\mathrm{K}$. Henderson consider the discrepancy between the EU's ability to reconcile resources and instruments and the expectations that exist inside and outside the EU as one of the main shortcomings of European policy in the region (Weaver, \& Henderson, 2010, p. 31). And although the approach to the BSR is characterized as "clumsy", the researchers stress that EU has numerous resources that make it still attractive. This attractiveness helps the Union to maintain this impression until it can act more effectively (Weaver, \& Henderson, 2010, p. 32-33).

\section{Prospects of EU policy towards the BSR}

Today, it is clear that, despite existing interests and existing political, economic, and humanitarian leverage, the EU has not been able to overcome the negative trends in the Black Sea Region. European values and norms, which were seen as the basis for reforming the region and their rapprochement and turned it into a zone of cooperation and interaction, strengthened political differences and ultimately provoked the return of the geopolitical confrontation between democratic (EU and NATO) and authoritarian (Russia) systems. In critically evaluating the results of European policy, analysts point to the need for the EU to take into account the new strategic landscape of the region and develop a new strategy for the BSR (The Black Sea, 2017; Acikmese, \& Triantaphyllou, 2014). 
In the current situation, the EU faces a difficult dilemma: how to use its soft power instruments to secure its own interests and fulfil its obligations to partners in the context of Russia's hybrid opposition, the answer to which will determine the EU's status in the region in the future.

First, its military-political dominance will allow the Kremlin to influence the countries of the region (for example, Ukraine and Georgia) in order to destabilize the internal situation and delay the pace of rapprochement with European structures; Bulgaria and Turkey will be influenced in order to limit NATO's presence in the Black Sea. Secondly, relying on force, Russia will create favourable conditions for the implementation of its own energy, economic, and infrastructure project not only in the BSR, but also further to the East. For example, analysts predict that Russia may repeat its previous pursuit of Ukrainian ships and blocking of ports against Romanian or Bulgarian Black Sea platforms, given that in 2014 Moscow unilaterally expanded exclusive economic zones (Celac, Dibenedetto, \& Purcăruş, 2019, p. 11). General B. Hodges also speaks of such a possibility: Russia is trying to establish full control and minimize the capabilities of other countries in the Black Sea by destabilizing actions, blocking the work of Ukrainian ports in Berdyansk, Mariupol, Odesa, and preventing the construction of a Deepwater port in the Georgian city of Anaklia (Ившина, 2020).

In addition to the threats posed to European energy and transport projects, the security threat is growing. Thus, Ukrainian and Romanian experts say that the security configuration of the Danube has changed as a result of Russia's policy in the Black Sea and that the escalation of tensions has affected the EU's relations with Turkey. In the event that Turkey restricts or closes navigation through the Bosporus, the Danube acts as an alternative route to the Black Sea for European naval forces. At the same time, the role of the Danube as a channel through which threats will penetrate Europe has grown.

Romania, a Danube and Black Sea country, is one of the biggest lobbyists for increasing attention toward the Black Sea. Even before full membership in the EU, Romania participated in the development of the Black Sea Synergy, emphasizing how important it was for the EU to pay more attention to the 'new neighbour' - the 'Black Sea Region' - and to implement a more consistent and coordinated policy (Angelescu, 2011, p. 128-130). Bucharest views the Black Sea Synergy as an important element of the ENP for the implementation of multilateral projects and the creation of a security and confidence zone in the BSR. Today, Romania uses all possible platforms to counter Russia's aggressive policy in the Black Sea, which is a threat to Romania's eastern borders and the EU as a whole and could lead to open conflicts near 
the Romanian border (Веремій, \& Паламарчук, 2020, p. 22) or isolate the country (Preventing Romania's, 2016).

Bucharest chooses cooperation with NATO partner countries (Bulgaria, Greece, Turkey), as well as with Ukraine, in order to strengthen security in the Black Sea as its main direction. The key focus is on conducting international naval exercises ("Riverine-2018", "Riverine-2019", "Platinum Eagle-2019", and "Riverine-2020" at the end of September). Among the tasks of these exercises are working out joint actions which can ensure the safety of civil shipping, conduct operations to monitor and maintain safety on the Danube.

In addition, Romania initiates or actively supports new platforms for regional and interregional cooperation. In particular, it is worth mentioning the Bucharest Nine and the Three Seas Initiative, which, according to Romania, should promote synergies between the national interests of the countries involved, regional processes, and EU policies aiming to improve the complex security environment in the Black Sea (Mureșan, \& Georgescu, 2017). Acting as BSEC Chairperson in 2020, Romania seeks to strengthen the EU's political and financial participation in Black Sea regional cooperation and to establish a flexible, results-oriented and closer cooperation between the BSEC and the EU in the interests of all member states and regional cooperation in general (Priorities of the Romanian, 2020).

Bucharest continues to lobby the Black Sea direction in EU institutions as well. In particular, during its presidency of the EU Council in the first half of 2019, Romania focused on strengthening regional cooperation in the Black Sea in the framework of Black Sea Synergy and the implementation of regional projects for sustainable economic development. Bucharest calls for greater coordination of the Black Sea Synergy with other Union policies and strategies, including or related to the BSR and for a substantial revision of the EU's objectives and policies in the region in order to increase "the visibility of the EU and its Member States" (Council Conclusions, 2019 ).

In this context, another weakness of the EU's Black Sea policy, which under pressure from Russia becomes a serious threat to the EU's subjectivity in the region, is the lack of a coherent common position of all EU members on strengthening the strategic approach to the BSR. A focus on projects on ecology, transport, shipping, human contacts, which are undoubtedly important elements of regional development, but do not meet the interests or goals of the EU, was declared in numerous association documents- in particular, the establishment of a global order based on norms and rules, as proclaimed in the EU Global Strategy 2016. Y. Tsantoulis (2009, p. 254). This focus expressed doubts about the ability of economic development, through the lens 
of regionalism, to serve as a catalyst for political reform, future prosperity, and stability in geopolitical competition. The current situation demonstrates that the BSR has become a space where international relations have been transformed from a liberal order to the return of revisionism, geopolitics and the establishment of new clear dividing lines in the region and the escalation of military-political confrontation. Essentially, what happened was exactly what the EU had been trying to prevent. This indicates the urgent need for the EU to reconsider its policy in the region- to change, according to D. Triantaphyllou (Triantaphyllou, 2014, p. 289-290), the paradigm and approach of the Union to the BSR. They must do so while taking into consideration Russia's negative impact on the transformation programs that the EU is promoting in the region and the EU's own limitations, including the interdependence between its role within the union and outside it.

\section{Conclusions}

The EU was one of the first to draw attention to the Black Sea Region as an area with the potential to become either a source of threats or a barrier to threats from the Middle East and Asia. In trying to prevent the development of the first option, the European Union takes on the role of promoter of a friendly atmosphere, seeks out economic and political reforms, and attempts to overcome the contradictions that divide the countries of the region. In addition, the EU has sought to help reduce the economic gap between the enlarged EU and its Black Sea neighbours. The EU's task was significant, which can be evidenced by economic interests, security considerations, and Europe's certain moral obligation to the countries of the region.

Unfortunately, the EU was incorrect in its assessment of the region's readiness to set aside contradictions and ambitions and join forces for the region's development. Another miscalculation was inflated expectations about the positive impact European initiatives would have on the processes of reforming of the political, economic, and legislative systems of the region.

The most serious problem for the EU has been the inconsistency of positions within the Union itself on the importance of the region, its interests, and on potential threats to Europe. This led to a large number of documents, statements, and declarations that did not contain a clear and understandable concept of EU policy towards the BSR. In addition, most documents are adopted as a reaction to certain events or actions of other actors in the region, and the decision is a compromise between the conflict of national interests, the EU's declared responsibility to neighbouring countries, and efforts to play a global role. These contradictions ultimately limited the potential of the 'transforming power' and the 'normative power' of the European Union and its instruments, reducing real incentives both within the Union and for regional partners. 
Scenario 1. Today, the situation has become even more complicated due to the establishment of strict control by Russia in the region, which still has a negative perception of the EU's regional activity. Thus, the strategic importance of the region for the EU is growing. Preliminary results of EU policy should be taken into account in order to move from an inclusive and complementary policy to a strategic approach based on a clear gradation of EU goals in the region, the unity of European states, a real understanding of risks and threats to European security and effective methods.

Scenario 2. A further lack of coordination and the dysfunction of the EU's policy towards the Black Sea region threaten to turn the EU into a minor actor in the region, which will lose it leverage over regional processes and force it to act only with regard to humanitarian projects. The biggest threat is the growing vulnerability of the EU's security position. This is well understood in Romania and Poland, but their efforts need to be supported by the most influential EU Member States.

\section{References}

1. Борьба за мир во всем море. О чем поспорили в Стамбуле черноморские державы и кто их примирял. (2017, Май 22). Коммерсант.RU. Взято 3 https://www.kommersant.ru/doc/3304665

2. Веремій, І., Паламарчук, М. (Ред.) (2020). Російська політика в Чорноморському регіоні: загрози й виклики для України. Київ: НІСД.

3. Віце-прем'єр України покладає на Росію відповідальність за кризу в ОЧЕС. (2017, Травень 22). Interfax Ukraine. Взято 3 https://ua.interfax.com. ua/news/general/423060.html

4. Глазова, А. (2012, Июнь 11). Черноморский регион: Зона особых интересов России. Национальная оборона. Взято з http://www.oborona.ru/ includes/periodics/geopolitics/2012/1106/13439485/detail.shtml

5. Гончар, М., Мартынюк, В., \& Ковалева, А. (2020, Август 11). Шанс на пробуждение после летаргии. Зеркало недели. Взято 3 https://zn.ua/ international/shans-na-probuzhdenie-posle-letarhii.html

6. Заквасин, А., \& Комарова, Е. (2020, Май 14). «Защита юга России и пресечение провокаций»: как проходит перевооружение Черноморского флота. $R T$. Взято з https://ru.rt.com/fzqj

7. Ившина, О. (2020, Июнь 5). Остановить «сирийский экспресс» России. Почему аналитики предлагают НАТО усилить посты в Черном море. BBC. Взято 3 https://www.bbc.com/russian/features-52938079

8. Кіфу, Ю. (2011). Місце і роль України в чорноморському регіоні: позиції фахівців. Національна безпека і оборона. 4-5 (122-123), 42-43.

9. Тріандафіллу, Д. (2011). Місце і роль України в чорноморському регіоні: позиції фахівців. Національна безпека і оборона, 4-5 (122-123), 48-50.

10. Acikmese, S. A., \& Triantaphyllou, D. (2014). The Black Sea Region: The Neighbourhood too Close to, yet still Far from the European Union. Journal of Balkan and Near Eastern Studies, 16:3, 279-285, 
11. Angelescu, I. (2011). New Eastern Perspectives? A Critical Analysis of Romania's Relations with Moldova, Ukraine and the Black Sea Region. Perspectives, 19, 2, 123-142.

12. Asmus, R. D., \& Jackson, B. P. (2004, June 1). The Black Sea and the Frontiers of Freedom. Hoover Institution. Retrieved from https://www.hoover.org/ research/black-sea-and-frontiers-freedom

13. Black sea countries complete preparations for implementation of Black Sea Ring project. (2016, August 23). World Highways. Retrieved from https:// www.worldhighways.com/wh10/wh8/feature/black-sea-countries-complete-preparations-implementation-black-sea-ring-project

14. Black Sea Synergy: review of a regional cooperation initiative - period 20152018. (SWD (2019) 100 final). (2019). Brussels: European External Action Service. Retrieved from https://eeas.europa.eu/sites/eeas/files/swd_2019_100_ f1_joint_staff_working_paper_en_v3_p1_1013788-1.pdf

15. Celac, S., Dibenedetto, A. G., \& Purcăruş, A. (2019). Militarization of the Black Sea and Eastern Mediterranean theatres A new challenge to NATO. Policy Paper. Retrieved from https://www.cesi-italia.org/contents/Analisi/ Militarization $\% 20$ of $\% 20$ the $\% 20$ Black\%20Sea.pdf

16. Coppieters, B. (2002). An EU Special Representative to a New Periphery. The South Caucasus: a Challenge for EU. Chaillot Papers, 65, 159-170.

17. Council Conclusions on the EU's engagement to the Black Sea regional cooperation. (2019, 17 June). Brussels: Council of the European Union. Retrieved from https://www.consilium.europa.eu/media/39779/st10219-en19.pdf

18. Laeken Declaration on the Future of the European Union. (2002). In From Nice to Laeken. European Defence: Core Documents. Chaillot Papers, 51, II, 112-119.

19. Los Fayos de, F. G. (2013). The EU's Black Sea policy: Where do we stand? Policy Briefing. European Parliament. Policy Department. Retrieved from https:// www.europarl.europa.eu/RegData/etudes/briefing_note/join/2013/491519/ EXPO-AFET_SP(2013)491519_EN.pdf

20. MEPs speak out in favour of more regional cooperation in the Black Sea region and the South Caucasus. (2008). European Parliament Press release. Retrieved from http://www.europarl.europa.eu/sides/getDoc.do?type=IM-PRESS\&reference $=20080115$ IPR $18588 \&$ format $=$ XML \&language $=\mathrm{EN}$

21. Mureșan, L., \& Georgescu, A. (2017, September - December). A Romanian Perspective on the Three Seas Initiative. The Market for Ideas. Retrieved from http://www.themarketforideas.com/a-romanian-perspective-on-the-three-seas-initiative-a314/

22. Preventing Romania's isolation. (2016, August 9). CEPA's Online Journal. Retrieved from: http://cepa.org/europes-edge/preventing-romanias-isolation

23. Priorities of the Romanian Chairmanship-in-Office. (2020, January 1 - December 31). BSEC. Retrieved from http://www.bsec-organization.org/chairmanship

24. Report on the strategic military situation in the Black Sea Basin following the illegal annexation of Crimea by Russia. 2015/2036 (INI). (2015). Brussels: European Parliament Committee on Foreign Affairs. Retrieved from https:// www.europarl.europa.eu/doceo/document/A-8-2015-0171_EN.pdf 
25. Schockenhoff, A. (2007). The Need for an EU Black Sea Policy. Working Paper. Retrieved from http://www.fondapol.org/wp-content/uploads/pdf/documents/DT_Mer_noire_ENG.pdf

26. The Black Sea - Confrontation or Cooperation? (2017, May 12-14). Varna Forum 2.0. Thinking Together. Bulgaria, Varna. Retrieved from https://library. fes.de/pdf-files/bueros/sofia/13825.pdf

27. The Black Sea Ring Highway will pass through the territory of Ukraine, Moldova and Romania. (2014, April 18). Ukrinform. Retrieved from https://www. ukrinform.net/rubric-economy/1650817-ukraine_moldova_romania_finalize black_sea ring highway route $320427 . \mathrm{html}$

28. Tocci, N. (2011). The EU in Conflict Resolution. In Wolff, S., \& Yakinthou, C. (Eds.). Conflict Resolution: Theories and Practice. London and New York: Routledge.

29. Triantaphyllou, D. (2014). The European Union and the Black Sea Region in Search of a Narrative or a New Paradigm. Journal of Balkan and Near Eastern Studies, 16, 3, 286-299.

30. Tsantoulis, Y. (2009). Geopolitics, (sub)regionalism, discourse and a troubled "power triangle" in the Black Sea. Southeast European and Black Sea Studies, 9(3), 243-258.

31. Weaver, C., \& Henderson, K. (Eds.). (2010). The Black Sea Region and EU Policy: The Challenge of Divergent Agendas. Ashgate Publishing, Ltd. 


\section{CHAPTER 6 \\ NATO IN THE BLACK SEA: TRANSFORMATION OF APPROACHES AND TAILORED PRESENCE}

(Hanna Shelest)

\section{Introduction}

2014 has dramatically changed the NATO approach towards the Black Sea region. While it still has been lacking coherent vision and strategic formulation, nevertheless, Alliance and its individual member-states separated the region and NATO policy towards it from the general scope of partnership policies. However, one of the main questions remained that NATO should answer whether the Black Sea region is a region of its responsibility or just a border (neighbourhood) region?

How paradoxically it can sound, but NATO received a second chance in the Black Sea region with the Russian illegal annexation of Crimea. Back in 2014, it was not seen as a chance for expansion, but as a time to transform policies and approaches, relations with partners, and own operational practices. De facto Turkish dominance in the Black Sea and desire to lead the region resulted in a situation when in 2014 there was a significant lack of understanding of the threats and challenges in the Black Sea region by the NATO officials. Having three member-states in the Black Sea has not translated into the NATO presence in the region. In some way, it suited the Alliance to rely solely on Turkey, delegating the responsibility for security, as no real threats had been expected (Shelest, 2016, p. 198).

As for today, even considering transformations happening, NATO still has predominantly a bilateral approach towards regional countries, when a necessity of the strategic regional vision is in need. NATO's Eastern flank in the Black Sea is a fractured security space that requires a special tailored approach (Vorotnyuk, 2020, p. 23). Moscow's offensives will have serious repercussions for the future of NATO by testing the alliance's political unity, strategic vision, US leadership, force deployments, mission operations, institutional willpower, and military capabilities (Bugajski, \& Doran, 2016, July).

Moreover, the 2014 events and on-going crisis raised an issue of what does NATO partnership really means, and can it guarantee the security of a non-member state? Should NATO return to Europe, and whether the Black Sea is seen as a part of Europe from NATO perspective? Georgia, together with Ukraine, faced the biggest opposition from the Russian side on their NATO membership aspirations. Some Georgian politicians even considered 
the Russian-Georgian war of 2008 as a punishment and warning to Georgia for its further Euroatlantic integration (Ondrejcsak, 2012). However, today both Georgia and Ukraine see NATO membership as an only chance to guarantee its security.

In this article, we will not pay full attention to the NATO-Russia relations, which deserve a separate analysis, but will touch them only in relation to the Black Sea region.

\section{Theoretical Approach}

NATO's role and activities in the Black Sea region are difficult to theorize due to its flux nature and multiply approaches. However, we consider it possible to see the last six years through the prism of realism and its power relations concepts and constructivism, as the new vision of the regional policies is being created.

From the political realism point of view, NATO's role in the Black Sea region should be predominantly seen in the framework of the two "powers" confrontation and a balance of power concept, as usually the situation is simplified to Russia vs. NATO relations. However, such an approach could be applied only to the hottest times of the Cold War. One of the reasons is that both adversaries should perceive each other in such a capacity. However if the Russian Federation has continued perceiving NATO and NATO enlargement as a danger and a threat so the North Atlantic Alliance had acted towards Russia, almost till 2014, as towards a partner, engaging it in different types of cooperation.

The collapse of the Soviet Union set a more comprehensive configuration in the Black Sea region. However, the search for a cooperation strategy instead of a confrontation one appeared to be long and vague. Moreover, with such a balance of power framework, it would be difficult to identify the rivalry sides clearly. The reason is that Turkey that, on the one hand, was seen as a representative of NATO policy in the Black Sea (as a member-state), on the other hand, after the end of the Cold War, often acted differently to Brussels, playing its own game with Russia, and de facto appearing as a third player.

Turkey's reservations about US long-term objectives in the Black Sea region became apparent when controversy erupted in the first months of 2006 over proposals to expand the activities of NATO's 'Operation Active Endeavour' to the Black Sea. Turkey and Russia jointly opposed the idea, though - for different reasons - Moscow was loath to see any expansion of US influence in its neighbourhood (Aydin, 2009), Turkey officially presented it as a concern to preserve the current legal regime of the Turkish Straits. Such Turkish position opposed a greater desire of Romania and Bulgaria - two new NATO member-states, for greater NATO and US involvement in the regional affairs. 
From the theoretical point of view, this example demonstrates that national interests of the states prevail over collective interests and a multilateral approach for the common good. Both Ankara and Moscow see the region through the glance of Realpolitik, where getting more power is the primary end of political action. In such a situation, the views of the NATO that has been transforming from military to the political-military alliance since the mid-1990s emphasized issues of democracy and shared values, as well as collective defence resonated Turkish view over the region just partially, when NATO was seen useful as a multilateral mechanism only within the framework of a more efficient collective, rather than national defence.

Turkish officials usually argued that the Black Sea security should be provided by the littoral countries of the Black Sea. Instead of increasing NATO military presence, Ankara de-facto blocked a US initiative to increase the role of NATO's Operation Active Endeavour in the Black Sea in 2006 and proposed expanding the BLACKSEAFOR and Operation Black Sea Harmony, which were almost copying Active Endeavour operation in the Mediterranean. In this regard, Russia and Turkey found a perfect compromise, preventing others from becoming involved in regional affairs. The Romanian disagreement was mostly ignored (Shelest, 2016, p. 198).

The Black Sea region definitely underlined the prerogative of national interests and power competition even within one international organization. "Against the backdrop of Turkey blocking more NATO presence in the Black Sea, Romania is trying to balance with more US presence and establish strategic partnerships, such as the one with Poland" (Krupa, 2018, p. 62). This competition for leadership in the Black Sea region between Turkey and Romania became evident for the last ten years with new initiatives put forward by both countries that could guarantee, by their view, more regional security. Both capitals attempted to present themselves as the best NATO ally in the region that can provide Brussels and partners with relevant information. But as a result, they did not capitalize against Russia but lost momentum when a real threat evoked.

The Russian actions in the Black Sea in relations to NATO's presence plainly can be explained by the realist theory as lay in a framework of its main thesis - a nation can only advance its interests against the interests of other nations and that a conflict or the threat thereof, is endemic to the system. Despite the NATO's perception of the relations with Russia as a new partnership, the highest level of interconnection without membership aspirations, - the Strategy of the National Security of the Russian Federation till 2020, adopted in 2009, clearly identified that "a defining factor in relations with the North Atlantic Treaty Organization is unacceptability for Russia of plans to advance 
Alliance's military infrastructure closer to its borders and attempts to attribute to it global functions that are inconsistent with international law" (Стратегия национальной безопасности, 2009).

The military doctrine of Russia, adopted in 2010, is going even further. In the whole document, NATO mentioned only twice - among other organizations, with which relations can be developed for conflict prevention and in a part dedicated to the main military dangers (they do not define it as a threat), describing it as a "desire to endow the power potential of North Atlantic Treaty Organization (NATO) with global functions carried out in violation of the international law, to bring the military infrastructure of NATO members-states to the borders of the Russian Federation, including by the bloc enlargement" (Военная доктрина, 2010). This line crystallized in the Black Sea region, and with further actions, such as constant navy provocations happening since 2014, made NATO confront a situation it has been trying to transform after 1991 - to be engaged in new power competition and rebalancing.

The problem was that Russia knew exactly what it opposed, but it offered little vision of what it wanted in terms of the regional security agenda (Antonenko, 2009). The modernization of the Russian Black Sea Fleet is one of the most ambitious elements of the Russian State Arms Procurement program for 2011-2020. Up to 18 new ships are being commissioned for the fleet, and new infrastructure developed. The purpose of this modernization is to build a combined arms force that can deny NATO access to the Black Sea and project power outward, threaten US and NATO interests in the Mediterranean and the Middle East (Bugajski, \& Doran, 2016, February).

It is the Black Sea, where Russia has chosen to test NATO's resolve in the eastern flank by the open use of force. A comparison of NATO's and Russia's conventional forces uncovers a significant asymmetry in favor of the former. In the Black Sea area, however, Russia has achieved certain comparative advantages (Vorotnyuk, 2020, p. 18). According to some opinions, in the case of the Black Sea, Russia can concentrate its forces in a relatively small area to gain an advantage, whereas NATO has limited access to these waters largely because of the stipulations in the 1936 Montreux Convention, which limits the naval presence of non-littoral states in the Black Sea (Bugajski, $\&$ Doran, 2016, February). Therefore, NATO appears in the situation of the constant search of new methods to balance Russian stance by conventional and unconventional ways - supporting partner states and organizing rotating presence of the NATO member-states ships in the Black Sea so as not to violate the Montreux Convention.

From the constructivist point of view, first of all, we are coming to a problem of region identification. Despite the geographical frames, the politi- 
cal borders of the Black Sea region have always been a disputing point, even for littoral states, not speaking about international organizations. So, when NATO is defining its policy towards the region, it should answer the question, which countries to cover. This answer is important as it influences the next steps of constructing the reality of existing relations, threats, and challenges, when one can be securitized and another one downgrade. As for now, from most of the NATO documents and plans, we can see that in addition to six littoral states, NATO also adds Moldova, Azerbaijan, and Armenia, even if the latter two slightly disappear from the focus. Moreover, NATO clearly distinguishes the Black Sea region from its Eastern Flank policy (towards Baltics and Eastern Europe) and the Middle East, as well as the Mediterranean. It has its positive moments as allowed to create more tailored made policies. But also, it has a negative effect as a limited vision of a comprehensive picture of threats, while an adversary, such as Russia, was defining its maritime policy with a Black Sea - Mediterranean projection, including the Middle East.

The second identification issue that constructed approaches and actions was an initial perception of the region. During the Cold War, divided between the Warsaw Pact and Turkey as a NATO member, the Black Sea region was perceived as a buffer zone without a great confrontation perspective since the Cuban crisis. After 1991, the region started to be identified as a region of cooperation, especially after the BSEC creation. However, while true for economic and social cooperation, in the security sphere, this region has not been defined as so. In 2020, the actors again define this region as an area of confrontation, so limiting other policy developments rather than those aimed at opposing your respective confronter.

In addition, a constructivist concept of perceptions/misperception is perfectly illustrated with a NATO - Russia stance in the Black Sea region. As a contested geostrategic zone, the remilitarization of the Black Sea is seen by Moscow as a necessary policy to prevent Russia's containment and any limitation of its powers around its western borders (Bugajski, \& Doran, 2016, February). The whole idea of the illegal annexation of Crimea was based on a fear that NATO ships can appear in the peninsula harbours (Direct Line, 2014), even when Ukraine had had a "non-block status" and Alliance had not had any real interest in the Black Sea, especially stationing any ships in Ukraine.

However, this "fear" was quite irrational and based on a Russian "mental map" of perceiving NATO only as an advisory and any "other" as able to be as assertive as Moscow in fighting for "spheres of influence." Therefore, if Kremlin misperceived NATO as preparing to deploy in the Black Sea, so Brussels misperceived Russia as a strategic partner being ready for greater 
involvement and partnership. For example, in NATO Strategic Concept 2010, the most outspoken paragraph is "NATO-Russia cooperation is of strategic importance as it contributes to creating a common space of peace, stability, and security. NATO poses no threat to Russia. On the contrary: we want to see a true strategic partnership between NATO and Russia, and we will act accordingly, with the expectation of reciprocity from Russia" (par.33) (Strategic Concept, 2010). At the same time, the National Security Strategy of the Russian Federation till 2020 (2009) identify NATO as following. First - "the failure of the existing global and regional architecture, focused, especially in the Euro-Atlantic region, only on the North Atlantic Treaty Organization, as well as the imperfection of legal instruments and mechanisms are increasingly posing a threat to international security" (par.8). And second: "The determining factor in relations with the North Atlantic Treaty Organization will remain the unacceptability for Russia of any plans to move the military infrastructure of the alliance to its borders and attempts to give it global functions, running counter to the norms of international law" (par.17). The same logic of arguments can be observed in other documents of the Alliance and the Russian Federation.

This logic of arguments and perceptions led to the miscalculations in NATO activities in the Black Sea region and their relation-building with the Black Sea partners - Ukraine and Georgia. This course of perception, while slightly changing, still has substantial support in Russia. As M. Vorotnyuk is writing, "The logic that NATO's attempt to be cautious with Russia prevents a major confrontation may have a serious flaw. The asymmetry of engagement can embolden the Kremlin and invite it to even more assertive actions, which eventually makes the conflict even more plausible" (Vorotnyuk, 2020, p. 19).

Yet the additional problem that influenced NATO approach towards the Black Sea before 2014 had been what Copenhagen school is naming a securitization of the issue. Securitizations of soft security issues in the 2000s (energy, trafficking, migration, environment) created false assumptions about the real stance in the security sphere in the Black Sea region, so NATO de facto has not seen its unique role there and was eager to delegate a problem-solver function to the European Union.

\section{4}

Transformation of the NATO approach towards the Black Sea after

NATO does not have a single official strategy towards the Black Sea region, still perceiving it mainly through the lens of the bilateral relations with separate states or its relations with already member-states. Discussing the Partnerships in its Strategic Concept (2010), it separates its relations with Russia, Mediterranean Dialogue, Ukraine, Georgia, Western Balkans, and the 
Middle East - but not even sees the Black Sea as a region, which needs a complex and regional approach. Back in 2004, R. Asmus was writing that the Black Sea region was perceived as a "kind of civilisational black hole in the Western historical consciousness" or as "Bermuda Triangle of Western strategic studies" (Asmus, 2004) that is why the West had paid just a little attention to it.

In 2004, experts insisted, "While a regional approach has long been part of NATO's partnership programs, there are no projects or cooperation programs, which have focused exclusively on the Black Sea region. The very concept of such a region is new to NATO, and the political and security waters of the sea remain largely uncharted" (Skonieczka, 2004, p. 99). After 2008, both NATO Bucharest Summit and Russian-Georgian war, many experts suggested that there is no place for NATO anymore in the Black Sea region, and the EU is the only one able to take security responsibilities in the region, as soft security and human security here are more important than hard security.

The Alliance itself has predominantly seen the region in the framework of their relations with Russia, not taking into consideration other regional actors' interests, looking at them through the lens of NATO-Russian relations. The Crimean annexation, Black Sea region militarization, threats to the security and safety of navigation became a trigger for NATO to reconsider its role in the region.

With the crisis in Ukraine in winter 2014, NATO has demonstrated that focusing a lot on the Wider Middle East, searching for new partnership formats in Africa and Brazil; it has almost lost its immediate neighbourhood. It also raises the question of what does partnership really means. Events in Ukraine confirmed that when NATO needed partner countries to assist with peace operations - they are more than welcome in Kosovo, Afghanistan, Iraq. But when the partner countries needed assistance facing the security crisis, NATO did not have mechanisms and sometimes goodwill to assist.

For quite a long time, the partnership concept, despite its name, was not perceived as cooperation of equals. Non-member states were mostly perceived as security importers rather than exporters. Only, at the NATO Summit in Wales in September 2014, the Secretary-General recognized, in the case of Georgia, that "As one of the largest non-NATO troop contributors to ISAF in Afghanistan, Georgia demonstrated itself as a security exporter" (Rasmussen, 2014), still it was not reflected the Black Sea region.

The conflict in and around Ukraine demonstrated that NATO was unable to fulfil one of its core tasks as defined in the Strategic Concept 2010 - "Crisis management. NATO has a unique and robust set of political and military capabilities to address the full spectrum of crises - before, during 
and after conflicts. NATO will actively employ an appropriate mix of those political and military tools to help manage developing crises that have the potential to affect Alliance security, before they escalate into conflicts; to stop on-going conflicts where they affect Alliance security" (Strategic Concept, 2010). However, most of the measures taken in response to renewed tensions with Russia have focused on defence on the borders of NATO. The Alliance understood that NATO would not be secure while the neighbourhood is in turmoil (Krupa, 2018, p. 64). Still, the question was whether NATO sees the Black Sea as those borders with Russia as most of the measures have been taken in Baltics and Poland.

Already in 2014, the partnership also gained a more substantial support dimension. In 2014, Georgia received the Substantial NATO - Georgia Package (SNGP) as part of the Defence and Related Security Capacity Building Initiative and joined NATO's Partnership Interoperability Initiative, allowing non-NATO partners to contribute to the Alliance's missions and exercises (Wales Summit Declaration, 2014). Ukraine, in addition to the new Trust Funds aimed at crisis response and significant military reform, also received the Comprehensive Assistance Package in 2016 aimed at both transformation of armed forces, capacity-building, and counter hybrid threats. What is more important, that in response to the Russian attack against Ukrainian navy ships in the Kerch Strait in November 2018, NATO Foreign Ministers agreed, in April 2019, a package of measures to improve NATO's situational awareness in the Black Sea region and strengthen support for partners Georgia and Ukraine - so-called "Black Sea Package" (NATO Foreign Ministers, 2019). This package, first of all, meant for Ukraine, provides for the surveillance, military presence, as well as support for the Ukrainian Navy and coastal defence (NATO package, 2019). In November 2019, NATO reviewed the implementation of the package of measures on the Black Sea security. As Secretary-General J. Stoltenberg said, "This includes the training of maritime forces and coast guards. Port visits and exercises. And sharing information. The recent visits of the North Atlantic Council to both Georgia and Ukraine were a good opportunity to see this package in action. NATO's standing naval groups have been exercising with Georgia and Ukrainian ships, improving our ability to work together" (NATO reviews, 2019). The importance of the Black Sea package not only in the clear identification of the Black Sea as a domain of activities but also in moving forward with the approach of "working together" with partners rather than providing one-way support.

It is worth analyzing the evaluation of the "legal" background of defining NATO's role in the Black Sea and its perception of the region. That can be made by studying NATO summit declarations and the Strategic Concept 
2010, as a new one is still under development, while the NATO reflection process is going on in 2020 .

2010 NATO Strategic Concept does not have any references to the Black Sea. However, it had a substantial number of statements about cooperation with Russia and a mere mentioning of Ukraine and Georgia as partners. This happened, as Turkey has been reluctant to act as NATO's anchor in the region, even blocking some US proposals on NATO's Black Sea Strategy, which had been considered at the Alliance's Istanbul Summit of 2004. It chose instead to separate its role and obligations as a NATO ally from its interests in the Black Sea region, which is still viewed as a matter of historic legacy and national identity (Antonenko, 2009). So only in 2014, a significant shift in documented manifestation of NATO's interest in the Black Sea region can be started to observe.

The Wales Summit Declaration 2014 refers to the Black Sea region once in the context of the Russian violation of the international law against Georgia, Moldova, UN Charter, Helsinki Final Act, etc. It is stated that "In addition, these developments may potentially have long-term effects on stability in the Black Sea region, which remains an important component of Euro-Atlantic security. Russia's current actions are contrary to the principles on which the established confidence building mechanisms in the Black Sea were built. We will continue to support, as appropriate, regional efforts by Black Sea littoral states aimed at ensuring security and stability" (Wales Summit Declaration, 2014). This statement clearly identifies the primary responsibility over the Black Sea region being delegated to the littoral state, while the Alliance, despite three littoral states were its members, it did not refer itself as a part of this region.

Warsaw Summit Communiqué 2016 pays more immense attention to the Black Sea. So Art.10, 17, and 23 refer to the Russian military build-up in Crimea and the Black Sea, which not only violates the international norms but also evolve challenges in the Baltic and the Black Sea regions. Comparing to the 2014 Declaration, the NATO states made two steps forward in their understanding of their role in the region. First of all, they emphasize the necessity of increased dialogue with Ukraine and Georgia - "We will continue to address the implications for NATO of developments in the region and take them into account in the Alliance's approaches and policies. We will continue to support, as appropriate, regional efforts by the Black Sea littoral states aimed at ensuring security and stability. We will also strengthen our dialogue and cooperation with Georgia and Ukraine in this regard" (Art. 23) (Warsaw Summit Communique, 2016). The second important step is defining new NATO tactics towards the region, where not the littoral states, but 
the organization as a whole is starting to play the first violin - "We will also develop tailored forward presence in the southeast part of the Alliance territory. Appropriate measures, tailored to the Black Sea region and including the Romanian initiative to establish a multinational framework brigade ... will contribute to the Alliance's strengthened deterrence and defence posture, situational awareness, and peacetime demonstration of NATO's intent to operate without constraint. It will also provide a strong signal of support to regional security" (Art. 41) (Warsaw Summit Communique, 2016). Such a step forward can be explained by the fact that NATO appeared in more appropriate to its status situation, comparing to 2014, when the real military threats, power projection, and activities for Alliance defence prevailed over the political competition with Russia.

Brussels Summit Declaration 2018 stresses that "a number of air and maritime measures in the Black Sea region have led to a substantial increase in NATO's presence and maritime activity in the Black Sea" (Art. 26), describing in detail new measures taken and forces deployed. Moreover, the Black Sea security appeared in sections about increased cooperation with Ukraine and Georgia, as emphasizing joint efforts of the Alliance and partner-states in countering hybrid warfare and increasing regional security.

At the same time, the London Summit Declaration, adopted in December 2019, as well as the Washington Statement on the occasion of NATO's 70th Anniversary, adopted in April 2019, are not referring to the Black Sea region, thus concentrating purely on the internal dimension of NATO adaptation.

Changes triggered by the illegal annexation of Crimea in 2014 raised awareness among many European states, which believed that the EU must have a security response and reconsider its foreign and security policies, which must be reflected in a reviewed European Security Strategy, European Maritime Security Strategy and the EU Strategy for the Black Sea (Motion for a European Parliament, 2015). However, no such reaction was noted within the NATO framework, which considered the Black Sea risks in a broader European context, emphasizing and enhancing security in the Baltics and at the Eastern flank, with the sea mostly left for the individual countries' initiatives.

It took NATO another two years of difficult negotiations to bolster its defence on the Eastern flank by deploying troops as part of the enhanced forward presence that is considered as a tripwire in case of hybrid or conventional attack by Russia (Krupa, 2018, p. 56). At the 2016 Summit in Warsaw, the allies decided to develop a "Tailored Forward Presence" in the Black Sea region. As a result, NATO's reinforcement strategy in the region concentrated on an air-policing mission in Romania and Bulgaria, a multinational brigade 
in Craiova (Romania), and a maritime component, a rotational presence of allied ships in the Black Sea. NATO's Very High Readiness Joint Task Force, the broader NATO Response Force, additional high readiness forces of the allies, and NATO's heavier follow-on forces, if necessary, will reinforce the forward presence forces. Tailored measures include more multinational land training, combined joint enhanced training, more maritime activity, and increased coordination to enhance NATO presence in three domains (Boosting NATO's Presence, 2019). The approval of the Enhanced Forward Presence in the Baltics and Poland, together with the Tailored Forward Presence in the Black Sea, are the most significant decisions taken by the Alliance since the end of the Cold War (Krupa, 2018, p. 67).

Romania has been a staunch advocate of enhanced NATO's military presence, which paradoxically resonated much better with Russia-alert Ukraine or Georgia, rather than with Bulgaria or Turkey (Vorotnyuk, 2020, p. 21). Experts stress that Romania being aware of the situation has been working with NATO to create a rapid-deployment capacity in the Black Sea that is similar to what NATO already has planned for the Baltic region and Poland (Coalson, 2016).

The resilience concept became a new approach towards the Black Sea region. The aim is to support the resilience of the most endangered partners in the NATO neighbourhood and is tailored to each partner in understanding the differences between them (Krupa, 2018, p. 64). The Black Sea region became a testing ground for this concept application and development. Recommendations and approaches adopted at the NATO Warsaw Summit in 2016 (Warsaw Summit Communiques, 2016) became core guidance for future cooperation.

In the 2018 Brussels Declaration, member-states confirmed that they would "continue to strengthen NATO's role in this regard, helping partners, upon request, to build stronger defence institutions, improve good governance, enhance their resilience, provide for their own security, and more effectively contribute to the fight against terrorism. This investment in partners' security contributes to our security" (par. 50) and that they would "also support Ukraine's efforts to strengthen its resilience against hybrid threats, including through intensifying activities under the NATO-Ukraine Platform on Countering Hybrid Warfare" (par. 66). To achieve this, Allies have strengthened their focus on areas of increased risk and are engaging with partners in the Black Sea region with the entire spectrum of instruments in their cooperative security toolbox. This includes regular consultations on the strategic assessment of the security situation in the Black Sea region, planning for relevant exercises, and accelerated practical support for Georgia, Moldova, and Ukraine (Anastasov, 2018). 
In 2018-2019, a number of the closed-door meeting had been held on discussing modalities of the Black Sea resilience within the NATO seven baseline requirements (Roepke, 2019). In January 2020, Ukraine and NATO agreed on the modalities of joint exercises on protecting critical infrastructure in the Black Sea region Coherent Resilience 2020, which would be held in Odesa in October 2020 (Ukraine and NATO, 2020). It was expected that participants from Ukraine and NATO member countries would work out algorithms of critical situations that might arise in the Black Sea region with the goal to respond in a coordinated, timely, and competent manner to cyber-attacks, port attacks, seizure of transport routes and other threats.

The Crimean crisis of 2014 has brought the necessity of reconsidering the NATO partnership concept. The inability or lack of will to use existed legal frameworks to secure Ukrainian territorial integrity and security raised questions about the real payback from the partnership. If during the Euromaidan events (November 2013 - February 2014) there was no place for NATO in Ukraine, Crimean events and further destabilization of the situation in Ukraine shifted the risks from soft security to the hard security sphere (Shelest, 2015, p. 280). Six years after, it is clear evidence of both the bigger role of NATO in the Black Sea and the Organization's readiness to rethink its partnership policies. Unique capabilities of particular countries (both NATO members and aspirants) must aggregate and complement one another. Only through such joint effort will they make conceivable elaboration and development of a unified strategy towards the region (Pkhaladze, 2020, p. 65).

\section{Conclusions and Scenarios of Future Development}

NATO needs both a precise formulation of its Black Sea Strategy, identification of existed and potential risks and threats, and greater application of its crisis management potential. If the 2014 Crimean crisis stimulated relations between NATO and other countries of the region, it took a long time to define their parameters. Only by 2018, a change of the NATO vision towards the Black Sea region is visible. Enhanced partnership, building resilience, greater involvement in regional affairs can be named as three main elements.

Analysis of the NATO summits declarations demonstrates the evolution of the approaches, greater attention to the region, while still an initial stage of own role definition. The absence of a clear short-term membership perspective for Ukraine and Georgia also contribute to this ambiguity.

Black Sea Strategy should go far beyond the membership issues because it is the main obstacle for the complex visioning and limits not only aspirant countries' involvement but also the neutral states like Moldova. The perception that if no membership perspective so no-active-involvement is an ill-structured concept, as the Black Sea region should be seen as an integral part of the NATO, not just as a neighbourhood. 
The Crimean crisis gave more arguments in favour of more significant NATO involvement when Turkey should be less reluctant to new collective initiatives, as both existed maritime cooperation initiatives have been suspended, and Turkey itself is not ready to guarantee regional security being more occupied on the South (Middle East).

Still, between Eastern and Southern Flank, NATO could not decide where the Black Sea belongs. While most of the Eastern Flank security enhancement initiatives are limiting its activities with Romania, South Flank remains covered by the Mediterranean, the Black Sea continues to be in strategic limbo. De facto, for NATO, the Black Sea is a region that can unite two flanks as most of its challenges are interconnected by strategic theatres. While limiting the Black Sea region only to the Eastern Flank will result in a dominance of the Russian-centred approach to threats and perspectives, so a comprehensive individual vision for the region will allow a complex, future-oriented approach and NATO's active role development.

Scenario 1 (on the grounds of Political Realism). Under this scenario, all parties involved will try to maximize their power, which will lead to greater competition and militarization of the Black Sea region. Considering that the interests of parties involved are opposing, we will see a decrease in security and an increase in alliances building to support competing powers in the Black Sea region. Under this scenario, NATO will need to increase its rotating presence in the Black Sea region, to consider greater involvement of Georgia and Ukraine in operational activities, with possible MAP introduction. Also, under such developments, the risk of incidents in the Black Sea region will increase, as well as possible provocations from the Russian side, which will try not only to maximize its power but also guarantee greater geographical cover. This scenario will get its full scope in case Turkey will stop its duality position in relations with Russia and NATO.

Scenario 2 (on the grounds of Constructivism). Under this scenario, NATO will need to construct its clear vision of the Black Sea region, minimizing the effect of the previously-made misperceptions. While accepting the different perceptions towards the vision, NATO needs to minimize a securitization of the soft power issues while developing capacities of both member-states and aspirant countries, using all possibilities of the Enhanced Opportunity Partnership that both Georgia and Ukraine are part of. In this case, developing the NATO Black Sea Strategy is the must, as it will allow clear identification of threats, goals, and a line of actions for the Alliance. "Smart Defence" concept can become a new paradigm of NATO activities in the Black Sea region, which will allow better use of all capacities and formulation of effective but not an aggressive defence. The use of smart defence 
principles can lead to greater involvement and joint security enhancement before the membership (Shelest, 2015, p. 283). Furthermore, it can promote better interoperability between NATO and its partners, one of the main tasks of the Alliance's partnership agreements.

\section{References}

1. Военная доктрина Российской Федерации [Military Doctrine of the Russian Federation] (2010). Official website of the President of the Russian Federation. Retrieved from http://news.kremlin.ru/ref_notes/461

2. Стратегия национальной безопасности Российской Федерации до 2020 года [National Security Strategy of the Russian Federation till 2020] (2009). Kremlin. Retrieved from http://kremlin.ru/supplement/424

3. Anastasov, P. (2018, May 25). The Black Sea region: a critical intersection. NATO Review. Retrieved from https://www.nato.int/docu/review/articles/2018/05/25/the-black-sea-region-a-critical-intersection/index.html

4. Antonenko, O. (2009). Towards a comprehensive regional security framework in the Black Sea region after the Russia - Georgia war. Southeast European and Black Sea Studies, 9:3, 259-269.

5. Asmus, R. (2004). Developing a New Euro-Atlantic Strategy for the Black Sea Region: Istanbul Paper \#2. German Marshall Fund. Retrieved from http:// www.gmfus.org/doc/07.28_GMFjstanbul2_Report.pdf

6. Aydin, M. (2009). Geographical Blessing versus Geopolitical Curse: Great Power Security Agendas for the Black Sea Region and a Turkish Alternative. Southeast European and Black Sea Studies, 9:3, 271-285.

7. Bugajski, J. \& Doran, P. (2016, February). Black Sea Rising. Russia's Strategy in Southeast Europe. Black Sea Strategic Report No. 1. Center for European Policy Analysis. Retrieved from http://cepa.org/sites/default/files/Black\%20 Sea\%20Rising.pdf.

8. Bugajski, J. \& Doran P. (2016, July). Black Sea Defended, NATO Responses to Russia's Black Sea Offensive. Strategic Report No. 2, Center for European Policy Analysis. Retrieved from https://www.cepa.org/black-sea-defended

9. Boosting NATO's Presence in the East and Southeast (2019, January 21). NATO. Retrieved from https://www.nato.int/cps/en/natohq/topics_136388. $\mathrm{htm}$

10. Brussels Summit Declaration (2018). NATO. Retrieved from https://www. nato.int/cps/en/natohq/official_texts_156624.htm

11. Coalson, R. (2016, February 23). News Analysis: Russian Buildup Focuses Concerns around the Black Sea. Radio Free Europe. Retrieved from http:// www.rferl.org/content/russia-black-sea-military-buildup-turkey/27569877. html

12. ComprehensiveAssistancePackage(2016). NATO.Retrievedfromhttps://www. nato.int/nato_static_fl2014/assets/pdf/pdf_2016_09/20160920_160920-compreh-ass-package-ukraine-en.pdf

13. Direct Line with Vladimir Putin (2014, April 17). Kremlin. Retrieved from http://en.kremlin.ru/events/president/news/20796 
14. Krupa, J. (2018). NATO. In H. Maksak, R. Turcsányi, \& M. Vorotnyuk (Eds.) Understanding Strategic Adaptations: Security Strategies and Policies After 2014, 56-72. Bratislava-Kyiv.

15. London Summit Declaration (2019). NATO. Retrieved from https://www. nato.int/cps/en/natohq/official_texts_171584.htm

16. Motion for a European Parliament Resolution on the strategic military situation in the Black Sea Basin following the illegal annexation of Crimea by Russia, 2015/2036(INI) (2015, May 21). European Parliament. Retrieved from http://www.europarl.europa.eu/sides/getDoc.do?type=REPORT\&reference $=\mathrm{A} 8-2015-0171$ \&language $=\mathrm{EN}$

17. NATO Foreign Ministers agree to enhance security in the Black Sea region (2019, April 4). NATO. Retrieved from https://www.nato.int/cps/en/natohq/ news_165253.htm

18. NATO package to support Ukraine in Black Sea contains confidential provisions - Klimkin (2019, April 5). UNIAN. Retrieved from https://www.unian. info/politics/10506531-nato-package-to-support-ukraine-in-black-sea-contains-confidential-provisions-klimkin.html

19. NATO reviews package of measures on Black Sea security (2019, November 21). UKRINFORM. Retrieved from https://www.ukrinform.net/rubric-polytics/2822556-nato-reviews-package-of-measures-on-black-sea-security.html

20. Ondrejcsák, R. (2012). Perspectives of NATO - Georgia Relations. In R. Ondrejcsák \& B. Gorka-Winter (Eds.). NATO's Future Partnerships, 47-58. Bratislava - Warszawa: CENAA - PISM.

21. Pkhaladze, T. (2020). Georgia and the Black Sea Security: Opportunities for Further Cooperation. UA: Ukraine Analytica, 1 (19), 61-65.

22. Rasmussen, A. F. (2014, September 4). Official Twitter. Retrieved from https:// twitter.com/AndersFoghR

23. Roepke, W-D. \& Thankey, H. (2019). Resilience: the first line of defence. NATO Review. Retrieved from https://www.nato.int/docu/review/articles/2019/02/27/resilience-the-first-line-of-defence/index.html

24. Shelest, H. (2015). Transformation of the NATO Partnership Concept in the Post-Soviet Space: Is Membership the Only Option? In R. Czulda, M. Madej (Eds.). Newcomers No More? Contemporary NATO and the Future of the Enlargement from the Perspective of "Post-Cold War" Members, 275-285. Springer Nature.

25. Shelest, H. (2016). The Change of the Military Balance in the Black Sea Region. In P. Bátor, R. Ondrejcsák (Eds.). PANORAMA of Global Security Environment 2015 - 2016, 193-203. Bratislava: STRATPOL.

26. Skonieczka, J. (2004). The Black Sea Region: A Role for NATO? In R. D. Asmus, K. Dimitrov \& J. Forbrig (Eds.). A New Euro-Atlantic Strategy for The Black Sea Region. German Marshall Fund.

27. Statement on the occasion of NATO's 70th Anniversary (2019). NATO. Retrieved from ato.int/cps/en/natohq/official_texts_165243.htm

28. Strategic Concept for the Defence and Security of the Members of the North Atlantic Treaty Organization (2010). NATO. Retrieved from https://www. nato.int/nato_static_fl2014/assets/pdf/pdf_publications/20120214_strategic-concept-2010-eng.pdf 
29. Vorotnyuk, M. (2020). Black Sea Security Deadlocks: NATO - Russia Confrontation. UA: Ukraine Analytica, 1(19), 18-23.

30. Ukraine and NATO agree on joint exercises in Odesa (2020). Cabinet of Ministers of Ukraine. Retrieved from https://www.kmu.gov.ua/en/news/ spilni-navchannya-ukrayini-i-nato-v-odesi-kuleba-i-kadenbah-pidpisali-dokument

31. Wales Summit Declaration (2014). NATO. Retrieved from https://www.nato. $\mathrm{int} / \mathrm{cps} / \mathrm{en} /$ natohq/official_texts_112964.htm

32. Warsaw Summit Communiqué (2016). NATO. Retrieved from https://www. nato.int/cps/en/natohq/official_texts_133169.htm 


\section{CHAPTER 7}

\section{FEATURES OF THE MODERN APPROACH OF CHINA TO THE BLACK SEA REGION COUNTRIES}

(Olga Brusylovska)

\section{Foreign policy of the Peoples Republic of China in the modern polit- ical literature}

The scientific discourse on Chinese foreign policy is characterized by a broad array of modern scientific approaches, representing both the Neoliberal and Neorealist schools of International Relations Theory.

The traditional literature on Chinese foreign policy is based on the concept of soft power first espoused by J. Nye Jr. Initially, this concept implied the usage of intangible resources, culture, beliefs, and political ideals to influence foreign countries' populations without the use of force. Joseph Nye defined soft power as the ability to achieve desired results in relations with other countries through the attractiveness of their own culture, cultural values, and foreign policy, rather than via coercion or financial resources (Nye, 2004); it also includes the ability of one actor to influence other countries through cooperation in specific areas aimed at persuasion and creation of a positive perception in order to achieve its own political goals (Nye, 2011). The following are the essential tools of the modern soft power: information flows, political PR, global marketing, the language of the country and its popularity in the world, public diplomacy, tourism, sports, cultural exchanges, the education system and student exchanges, the ability to conduct information wars and migration policy (Nye, 2011). The use of soft power is often mistakenly identified with propaganda. Propaganda does not exclude various options for manipulating people's minds, but the soft power concept does not allow this.

Marlene Laruelle and Wei (Josh) Luo (the George Washington University) criticize Joseph Nye's theory of soft power because of its "two problematic assumptions: soft power is accumulated only by countries with liberal systems... and the United States is the yardstick for measuring its influence. The assumption that illiberal countries cannot develop the soft power that attracts audiences abroad limits our ability to understand how non-liberal policies and politicians are gaining momentum. Moreover, the look through the US-focused prism overshadows the niche forms of soft power conducted by the other countries" (Laruelle, \& Luo, 2020, p. 1). In their opinion, it also should be mentioned that even Nye himself admitted that Hitler, Stalin, and Mao had "a large amount of soft power in their policies". Furthermore, today it is impossible to deny that the Peoples Republic of China skilfully applies various 'attraction' tools. 
According to Daniele Carminati (the University of Hong Kong), "soft power is generally seen as something that depends on many non-governmental actors, such as the private sector and civil society. The Chinese soft (and hard) efforts are centralized and controlled by the government". This distinctive feature leads to the limitation of one resource, such as developing an attractive mass culture and, on the other hand, increasing the others, such as the rapid allocation and use of financial and human resources. "The modern Chinese strategies emphasize the decision-makers' willingness to test such political instruments' boundaries as 'the attraction' and 'the motivation"" (Carminati, 2020, p. 2).

The soft power of China relies heavily on its economic tools. In his book "Magic attack: How Chinese soft power is transforming the world", Joshua Kurlantzick was the first to point out that China's definition of the soft power is quite inclusive. Through international aid, the PRC is almost erasing the boundaries between soft power and economic power. John Wong noted that China is building its soft economic power, including skilful economic diplomacy through regional trade agreements or expansions of the Official Development Assistance (ODA). David Shambaugh, one of the leading experts on Chinese diplomacy, argued that the most potent tool in Beijing's toolbar is money (Carminati, 2020, p. 1).

The example of the close interaction of China's soft power and economic power could be the Chinese Diaspora's financial support in other countries. That is why observers say that the PRC's strategy is "not so soft" (Carminati, 2020 , p. 2). Some modern studies describe the PRC's behaviour as a form of deceptive and manipulative 'sharp force', but these studies' methods are not convincing enough. We could say that the soft power of the PRC 'sharpens' only if it is indispensable.

The latest trend in the literature that studies the Chinese foreign policy is to identify China's modern strategy as 'irrational behaviour'. The term refers to the growth of the Chinese aggressiveness. In this regard, Edward Luttwak expressed the claim that the country is affected by the so-called 'great-power autism' caused by its strategic culture (belief in centrality and hierarchical superiority) and the inability to process information about internal and external events simultaneously. The syndrome is characterized by the "insensitivity of the Chinese leadership to the sensitivity of others". In other words, Luttwak claimed that the leadership of China has become indifferent to the growing opposition from its neighbours in its aggressive policies. Besides, as Thomas Christensen pointed out, the PRC's 'irrational' behaviour after the recession had its roots in internal dynamics (the rise of nationalism, lack of bureaucratic coordination, pluralism in foreign policy decisions, and unfair transactions) (Palanisami, 2020, p. 1). 
On the contrary, Aaron Friedberg argued that China's assertive nature is not related to a spontaneous response caused by internal factors, but is a wellplanned strategy adopted after the global economic crisis of 2008, which led to a relative increase of China's power. Moreover, he countered that the continuation of assertiveness might be due to a long-time trend. Calling China's behaviour 'rational', Friedberg refuted Luttwak's claim that China "suffers from the great-power autism" (Palanisami, 2020, p.1).

Approximately the same views are reflected in the work of Ramez Raja (the Jamia Millia Islamia) and Zakhor Ahmad Dar (the Jawaharlal Nehru University). They believe that Beijing's strong position toward the Hong Kong National Security Law reflects its strategic behaviour. "It is a sign of a dominant force: any state can behave aggressively if its strategic interests are challenged by an out-of-system player" (the USA). China strengthened the international framework of international political structures due to its impeccable growth and development (Raja \& Dar, 2020, p. 1). However, while China wants to 'rise peacefully', it is also concentrating its military force, strengthening nuclear and conventional forces to ensure its strategic interests: "If the US becomes provocative, Beijing's aggressiveness may increase accordingly." (Raja, \& Dar, 2020, p. 4).

The Chinese leadership turned to the soft power concept in the 2000s after Hu Jintao became the General Secretary of the CPC Central Committee. There was a broad discussion in the party-governmental apparatus and the expert community about the possibility of using the soft power according to the national interest and the Chinese specifics. In 1993, Professor Wang Hunying published an article "Culture - soft power of state power", which introduced a new concept for China (Callahan, \& Barabantseva, 2017, p. 49). In 2004 Deputy Premier of the State Council of China Qian Qichen published an article claiming that after the events of September 11, the United States "got into a difficult situation: underestimating the role of the soft power and international institutions by turning back to the hard power, which has already shown its inefficiency" (Callahan, \& Barabantseva, 2017, p. 116). Chinese scientists have identified four essential components of China's soft power: the power of culture, the power of politics, the power of diplomacy, and the power of society. In modern scientific publications, the question of what exactly is of primary importance in the construction of a national concept is polemical: 'soft power of culture' or 'soft power of politics'. Chinese scientists' views were divided, resulting in two independent scientific directions of China's soft power studies (Цзайци, 2009, с. 167). According to Yiping Wu (the Zhejiang Gongshang University), China's standard image of Mao Zedong's era - old-regime authoritarianism - was demolished a long time ago. In the ten 
years between 2003 and 2013 alone, the State Council of China and the National People's Congress (NPC) passed 336 new regulations and laws (Wu, 2020, p. 236). Today, attention should be drawn to the recent development of an active and successful media, think tanks, experts from non-governmental organizations, and other policy actors in the decision-making process $(\mathrm{Wu}$, 2020, p. 237). Thus, the study of China's foreign policy today should take into account not only that the one-party state excludes public actors from power exchanges, but also that the regime is becoming more tolerant and more sensitive to public participation and public criticism on foreign policy issues.

China and the Black Sea region: political and diplomatic aspects

In recent years we have seen the emergence of not only new literature on the Chinese foreign policy but also a new 'brand' of Chinese diplomacy, described by Rahul Palanisami (the Jawaharlal Nehru University). Unlike the older generation of diplomats, who used conservative and passive diplomacy, modern so-called 'wolf warriors' have become known for their aggressive and proactive tactics (Palanisami, 2020, p. 1). They got their name from popular Chinese action movies' heroic characters, where usually a lone 'wolf warrior' saves the world from some global threat. Chinese diplomats of the new generation began to be called 'wolf diplomats'. They are adept at using social media platforms like Twitter to protect Chinese national interests. During the Covid-19 pandemic, these 'wolf diplomats' used out in full force on social media platforms, responding aggressively to challenges from the United States. They were also responsible for spreading misinformation about the coronavirus's origin and the Western response to the pandemic. According to Sergii Korsunsky, "China, of course, has become more aggressive, because there are two main goals at stake, formulated by the current leadership of the PRC: to reach the level of a 'moderately flourishing country' by 2021 and to make China a 'rich, influential, democratic, civilized and harmonious' country by 2049. Therefore, nothing could stop it." (Корсунський, 2020). Thus, in general, during the pandemic period, there was an increase in Chinese diplomats' activity on the world stage.

If we compare Chinese aggressiveness during the global financial crisis of 2007-2008 and Chinese diplomacy at the peak of the coronavirus pandemic, it must be noted that China suffered relatively little damage compared to the Western liberal democracies. The situation encouraged the Chinese government to promote its governance model as the best alternative to the Western one (Palanisami, 2020, p. 1). The Chinese foreign policy has moved away from Deng Xiaoping's principles of "keeping a low profile" in international affairs and "not claiming leadership". 
China's political system has become more centralized under President Xi Jinping, who became the CPC General Secretary and President of China in 2012-2013. Chairman Xi set the goal of "rejuvenating the Chinese nation". In November 2012, he created the Central National Security Commission (CNSC), which fell under the CPC Central Committee's leadership and reported directly to the Politburo.

In 2018, the Central Foreign Affairs Commission (CFAC) replaced the former Commission on Foreign Affairs. As well as the National Security Commission, the CFAC is also led by Chairman $\mathrm{Xi}$ and other CPC key figures. Since its formation, the CFAC has functioned as a critical institution coordinating China's foreign policy. It also marked an even more important centralization of decision-making in China's foreign policy. However, this system's significant drawback is that the Communist party's loyalty when promoting senior positions is valued above candidates' regional experience. A great example of this situation could be the composition of the CFAC, filled with people who do not have foreign policy knowledge. Some experts argue the creation of the CFAC has added a layer of bureaucracy to an already inefficient political process. However, according to Palanisami, possible advantages include explicit external markers and predictable foreign policy. Observing the changes made by President Xi, we can conclude that the modern diplomatic aggressiveness of the 'wolf warriors' is sanctioned from the top; in China, unlike in democratic countries, interest groups do not influence policy-making. Simultaneously, more aggressive diplomatic behaviour serves as a tool to distract the population from the economic drawbacks of the trade war with the United States, the coronavirus pandemic, and the protests in Hong Kong (Palanisami, 2020, p. 2).

One of the most exciting parts is the development of the modern decision-making process in China. Once a year, the Chinese elites gather in Beidaihe, Hebei province, $300 \mathrm{~km}$ away from the capital, to hold public consultations on the latest issues. The leaders of the Communist Party of China, their advisers and assistants, the brightest minds from the scientific field, former officials whose opinion is still relevant, and even the spiritual leaders of Tibet are searching for the 'middle way' ('way of life') on foreign and domestic policy issues. The 'middle way' means negotiating with utmost patience, implementing plans despite its criticism, consistently moving along the "one belt, one road" megaproject, and 5G telecommunications lines. Usually, what is agreed in the 'summer capital' is later implemented through decisions of the party bodies, the Parliament, and the government (Корсунський, 2020).

While the structure of foreign policy decision-making has undergone radical changes since 2012, the tools for implementing them have remained 
rather traditional. The most important diplomatic tool of the PRC is the intensification of bilateral relations. It should be noted that bilateral relations for the Chinese side have always been more important than multilateral ones because they give more freedom to manoeuvre and apply various strategies. China seeks to solve all problems individually on each side or do nothing and "continue to rule the river as from its source to the river mouth" (Rong, 2018). This Chinese trait is particularly evident in the Black Sea region because it is much less structured and bound by agreements than in, for example, the Baltic or North American region.

Given that the most massive Black Sea region organization, the BSEC, is relatively passive, we can even raise the question of the region's existence in any sense other than the geographical one. For non-system (external) actors, the weakness of ties and several internal regional problems makes it incredibly tempting to play on their contradictions. Therefore, China, Iran, and the Persian Gulf countries gradually increase their influence in the Black Sea region.

The situation caused considerable dissatisfaction from the initiator of the creation of the BSEC - Turkey. The strategic concept of "Stratejik Derinlik" by A. Davutoglu (2001) was based on the fact that Turkey is a Middle Eastern, Balkan, Caucasian, Central Asian, Caspian, Mediterranean, and Black Sea regional power, and can play a strategic role in all these regions simultaneously and thus claim a global role. However, the re-evaluation of its policy during 2002-2009 slightly changed the critical concept: Turkey was still seen as "destined to take a central place in international relations", but the task of reducing its dependence on the West led to the goal of establishing relations with the non-Western countries like Russia, Iran, and China (Мавріна, 2012, p. 49-52). In 2010, the parties first discussed the possibility of establishing strategic partnership relations, and in 2015, the Chinese President Xi Jinping and Turkish President Tayyip Recep Erdogan agreed to develop "strategic cooperation based on mutual respect." (“Голова КНР Ci", 2015). Nevertheless, political and diplomatic relations between the two countries look much more vulnerable than their economic component. The reason for this is not only the Uighur issue, which is essential for Turkey, but also the fact that the parties in the Black Sea region behave more like rivals than partners.

Special priority for China in the region is the Russian Federation, one of the most influential players in the Black Sea region and the Republic of Turkey. Moreover, China is one of the strategic neighbours and partners of the Russian Federation. It is not surprising that China's global goals define regional relations. In this context, problems related to the shared border have set the agenda of the Russian-Chinese relations for many years. Moreover, only 
after May 20, 2005, the State Duma has ratified the agreement on the Russian-Chinese border's demarcation line. After that, China has begun to develop more significant activities toward the Russian Federation (Карпов, 2013). The agreement eliminated the most crucial tension points, which, in the future, could lead to an aggravation of relations (Галенович, 2010, p. 35). After that, the parties officially defined the Russian-Chinese relations as "comprehensive, equal, trusting partnership and strategic interaction" ("Концепция внешней политики", 2019). The main principles and directions of bilateral cooperation are reflected in the Treaty of Good Neighbourhood, Friendship, and Cooperation of July 16, 2001 (“Договор о добрососедстве”, 2001). Russian President Vladimir Putin and the Chinese President Xi Jinping meet at least five times each year. Since 1996, a mechanism of regular meetings includes Russian and Chinese government head annual visits, Foreign Ministers annual meetings, and regular meetings during different international events, particularly during summits of the UN, Group of Twenty, the APEC, BRICS, and SCO. The two countries' foreign ministries have a system of scheduled consultations at Deputy Ministers and Department Directors levels. More than 300 intergovernmental agreements were signed, which cover almost all areas of possible cooperation (Давыдов, 2004). Nevertheless, both countries act according to their national interests on the global and regional levels, which do not always contribute to their bilateral cooperation.

However, it is easy to see that Ukraine has always been much lower than Russia in China's priority ladder. Relations between our countries developed slowly and did not go beyond trade and investment interests. In June 2011, during Chinese President Hu Jintao's visit, the "Joint Declaration on the establishment and development of strategic partnership relations" was signed in Kyiv, and several contracts worth USD 3.5 billion were implemented. By the end of 2011, the trade turnover exceeded the milestone of USD 10 billion (Шевырев, 2011). Nevertheless, the implementation of these and previously signed documents stalled, and after 2013, relations generally changed for the worse.

The line of China's behaviour concerning the Ukrainian crisis of 20132014 and the Russian-Ukrainian war of 2014-2020 was formed according to China's national interests, which, with its resources and multiple geo-economic and geopolitical projects, gradually have turned it into a superpower. Beijing's position reflected China's "principle of neutrality" in world conflicts, corresponded to its political and economic interests in Europe, and plans to restart the Sino-American relations.

The first reaction of China to the aggravated situation around Ukraine was relatively restrained. He limited himself to statements about non-in- 
terference and the need for peaceful, diplomatic methods of resolving the conflict. Nevertheless, soon, China blamed external forces for the deterioration of Ukraine's political situation: Beijing accused the West of manipulating 'people's opinions' about the Association Agreement with the European Union. "The Western intervention has hindered dialogue between the government and the opposition, sowing the seeds of further social and political discord within the country", Xinhua reported (“Китай недоволен”, 2013). Ukraine's situation has affected China's global and regional interests and exposed its foreign policy to certain risks. On February 24, 2014, the Chinese Foreign Ministry spokeswoman Hua Chunying said: "We hope that the political process of resolving the Ukrainian crisis will move forward within the legal framework". China suggested that the Ukrainian sides protect different Ukrainian peoples' legitimate interests in practice, as China drew attention to the then-newly and rapidly inflamed the Russophobic sentiments (“Очередная пресс-конференция”, 2014).

During the UN Security Council's vote on Crimea's issue, China abstained from voting, and Russia used a veto on the relevant resolution. Therefore, the Ukrainian Foreign Ministry demanded that Chinese diplomats explain their position. Their Ambassador in Ukraine, Zhang Xiyun, said that one of the basic principles of the Chinese foreign policy is non-interference. However, this could not satisfy Kyiv, looking for international support regarding the Crimean referendum's recognition as invalid, and Moscow's policies as aggression. At the UN Security Council meeting on March 16, 2014, China's permanent representative to the UN, Liu Jie, proposed China's mediation in resolving this issue. He suggested, firstly, "creating an international coordination mechanism with the participation of interested parties to work out a political solution to the Ukrainian crisis". Secondly, he called on all parties to refrain from actions that could further escalate the conflict. Liu Jie said that the vote on the United States' draft resolution would only "increase the confrontation and further complication of the situation". Also, he recalled that 'external interference' was "an important reason that led to violent actions on the streets of Ukrainian cities, which caused a crisis in the country" ("China Makes Proposals", 2014). Besides, the official media of China condemned the policy of the United States and its allies. On March 19, 2014, the Xinhua News Agency issued a comment about the West's commitment to double standards and solely to its interests, which was manifested in a wide geographical range "from Kosovo to South Ossetia, as well as from Comoros to Crimea” (Покась, 2017, p. 147).

On March 6, 2014, in a conversation with the US President's National Security Advisor, Susan Rice, the Chinese national security adviser, Yang 
Jiechi, emphasized that "the legitimate rights and interests of all ethnic groups in Ukraine should be taken into account during the resolving of the Ukrainian problem" ("Chinese State Councilor", 2014). China attempts to consider all the difficulties with EU, Russia, Ukraine, and the United States relations with apparent neutrality. However, it has a noticeable 'tilt' toward Russia, which can be shown by an analysis of Chinese mass media. According to the German magazine Der Spiegel, the leading Chinese media's 'strong words' about Russia confirmed that "the most populous country in the world stands on the side of the largest country in the confrontation between Russia and the West" (Клусман, 2014).

Moreover, the newspaper "Huanqiu Shibao" noted: "People who support Moscow believe that Russia's actions are a reaction to long-term strategic pressure from the West...We are more inclined to agree with those who support Russia” (Покась, 2017, p. 148). Thus, until the Russian-Ukrainian conflict is resolved, there is no need to talk about establishing political cooperation between China and Ukraine.

On the contrary, Eurasia's rational and restrained behaviour allowed China to pursue a positive and inclusive policy in the Caucasian region. China has managed to make it clear that it is ready to talk to everyone without any restrictions. Furthermore, they are willing to do this without causing the dissatisfaction of regional states (primarily Russia) who are claiming leadership in this region (Леонова, 2013, p. 37).

Consider Armenia, with which a defence agreement containing a provision on mutual military support was signed in 2015 . Yerevan has officially agreed to participate in the Chinese project of the new Silk Road (Роллан, 2018). This friendship was reinforced by Chinese investments and strategic decisions for the Armenian economy. For Armenia, positive bilateral relations with China play an important role: the economy's situation is difficult, and an investor like Beijing can radically change the situation. Besides, strengthening friendly ties with Beijing (they have existed and been developing since 1996) can help Armenia to break out of Russia's grip so that it does not feel threatened at the same time.

Chinese diplomacy is establishing friendly relations, not only with Yerevan. Recently, it has managed to establish close ties with Azerbaijan. Baku did not forget that Beijing refused to support the UN resolution on Armenian forces' withdrawal from the occupied Azerbaijani territories in 2008. However, China has shown that it is not equal to any other 'political camps' in the region.

On the other hand, China's political and diplomatic relations with Bulgaria and Romania have been hostile since they joined the EU in 2007. The 
EU newcomers have lost some of their sovereignty by transferring crucial foreign policy tools to Brussels. As a result, now they are forced to adhere to the principles of the EU's standard foreign and security policy.

The unprecedented COVID-19 pandemic has undermined relations between the EU and China. According to Karim Salem, "China attempted to divide Europe during the health crisis. It used openly hostile rhetoric about Western democracy's ability to respond to emergencies. It served as a strong impetus for Europe to become more assertive with China when its interests and values are questioned." (Salem, 2020, p. 1).

An essential factor in China-EU relations was the growing tension between the US and China. Both forces are increasing pressure on the European countries according to their strategic interests. This is particularly notable concerning the Chinese telecommunication giant's role, Huawei, which is providing $5 \mathrm{G}$ networks to the European countries. The US is calling for Huawei to be excluded from European 5G networks. Similarly, the Chinese government has increased pressure on European countries not to exclude the Chinese operator, providing next generation technologies. The COVID-19 pandemic has accelerated and dramatically increased the tension between China and the United States. President Donald Trump called COVID-19 a 'Chinese virus', while the senior Chinese officials claimed that the US created the virus and placed it in China in winter 2019. The White House went even further, withdrawing the US representatives from the World Health Organization. This was done in response to the fact that the WHO allegedly supports China. Recently, tensions had increased further when both sides closed their consulates (Salem, 2020, p. 1).

It does not mean that Europe will be forced to focus on Trump's position toward China. Europe attempts to meet its interests, focusing on cooperation and partnership with China on climate change, global governance, sustainable development, and expanding agricultural trade. At the same time, Europe resists the deepening authoritarianism in Hong Kong and Xinjiang province and strengthens its strategic autonomy in health, technology, and industry.

Concerning the Post-Soviet States of the Black Sea region, China is guided primarily by Russia's partnership. However, when it comes to Bulgaria and Romania, China's priority is in partnership with the EU. This complex interdependence and subordination of regional tasks to global tasks significantly limit China's current Black Sea region activity.

The economy as a tool of the PRC's policy in the Black Sea Region

In considering each region's specifics, China focuses on the soft power tools that will bring the most significant benefit to the state. To implement its policy, the PRC uses the main tools of economic, diplomatic, and humanitar- 
ian soft power. China does not perceive military-political alliances instead of focusing on trade and economic cooperation (Callahan, \& Barabantseva, 2012, p. 110). For example, over the past ten years, Turkey and China have signed several agreements to intensify economic and trade cooperation. One of the most important agreements is a framework agreement on expanding trade and economic cooperation and an agreement on the joint implementation of infrastructure projects in the third country. The last agreement type includes creating a working group on the Silk Road project in the Black Sea region. In particular, it should enhance trade relations between Turkey and China with the other countries of the Caucasian region. In April 2012, Turkey and China signed two agreements on nuclear energy, a high-speed railway between Ankara and Istanbul, and an agreement to build a nuclear power plant in Turkey. Besides, it was announced that the two-way trade payments would be conducted in national currencies. China was the third country (after Russia and Iran) with which Turkey has concluded such an agreement. This agreement highlights the growing influence of the PRC in Turkey (Мавріна, 2012, p. 64). In 2015 the Chinese President Xi Jinping put forward three proposals to enhance bilateral relations with Turkey. The first is to use the intergovernmental commission mechanism on cooperation at the level of the Deputy heads of government. The second is to focus on cooperation in the areas of high-speed railways and new energy sources. The third is to promote cooperation in three new areas: space, finance, and investment. According to Chairman Xi, the Chinese government will consistently encourage Chinese enterprises to make investments and conduct business with Turkey ("Голова KHP Ci”, 2015).

The economy is an essential component of China's policy concerning Russia. In purely economic terms, interaction with the United States and the Western countries is more important for China than trade and joint projects with Russia. However, Russia and China's geopolitical position implies an equalization of cross-border economic activity. In the global market, countries are at an unequal position in terms of strategic development (Barnett, \& Duvall, 2005). Russia directs its efforts to protect its interests from the position of the 'besieged fortress'. China meanwhile directs its efforts to protect its interests and develop its political presence worldwide based on multilateral cooperation (Карпов, 2013).

The cornerstone of Russian-Chinese economic relations is oil. On May 21, 2014, Russia's Gazprom and China National Petroleum Corporation (CNPC) signed a thirty-year gas supply agreement. The contract outlines the supply of up to 38 billion cubic meters of natural gas with a total price of USD 400 billion over 30 years. It is the largest gas supply agreement in the history 
of the USSR and modern Russia combined (“Газпром возобновил", 2020). China notes the continued growth of energy exports from Russia. In turn, the most significant increase in imports from China to Russia was in the sphere of "electric machinery, its equipment, and parts". According to the General Customs Administration of China report, China's exports to Russia decreased by $14.6 \%$ in 2020 (USD 9.151 billion). Simultaneously, imports of Russian goods to China increased by $17.3 \%$ (USD 16.202 billion) ("Товарооборот России", 2020).

In Ukraine, China is primarily interested in the field of military technology cooperation. At its disposal, Ukraine has research groups in almost the entire range of modern weaponry, from aircraft carriers to intercontinental ballistic missiles. China has found a way of converting growing economic power into military power. Therefore, the possibility of acquiring several military technologies should not be underestimated. Beijing has shown interest in about 30 military technology cooperation areas, including aircraft carriers, large transport aircraft, supersonic training jets, tanks, air-to-air and air-toground missiles. Cooperation with Ukraine helped put into operation the aircraft carrier "Liaoning" (it was equipped with Ukrainian gas turbines UGT25000 or DN/DA-80) and to achieve success in developing new warships, tanks, and aircraft, especially aircraft engines. According to the Chinese Defence Review, in the 1990s, China received these turbines without production technologies. Later Ukraine agreed to transfer all the technologies to China ("20 років", 2014). According to the Stockholm International Peace Research Institute (SIPRI), China ranked second after Pakistan among Ukrainian weapons importers with USD 624 million turnovers in 1992-2008.

Moreover, since 2009, China has become the number one economic partner of Ukraine, but this may not last for too long (Тымчук, 2017). Today, the prospects for military technology cooperation between Ukraine and China look uncertain. Firstly, China's leading partner, the state enterprise "Ukroboronprom" has mainly focused on meeting the increased defence needs of Ukraine since 2014, which has caused a decline in external supplies of military equipment (Терещенко, 2014). Secondly, the interaction between Ukraine and the EU leads to reducing the arms trade with China. That was caused by the EU rules on the embargo on the supply of dual-use weapons and equipment. Lastly, during these 25 years, China has already received all the necessary military technologies from Ukraine. Added to all of this is the fact that the development of new technologies in Ukraine has been prolonged due to underfunding.

The Ukrainian market is not big enough, and the economy's investment is hindered by bureaucracy and high government corruption levels. There- 
fore, Ukraine's trade and economic relations and investment activities have not become one of China's priorities. Ukraine's share in China's total trade volume is minimal and amounts to only $0.18 \%$ (“Торговельно-економічне співробітництво", 2020). The Ukrainian-Chinese intergovernmental commission has not met since October 2013. The long pause in political relations has affected economic indicators, including bilateral trade and investment. There has been a rapid collapse in trade compared to the pre-war years when the trade turnover was more than USD 10 billion. Since 2015, the trade turnover between Ukraine and China has not exceeded the USD 6 billion milestone (“Торговельно-економічне співробітництво”, 2020).

Considering the PRC's economic soft power in the three Caucasian republics, it should be noted that China has identified three main sectors in economic cooperation. These sectors are the chemical industry in Armenia, the automobile industry in Azerbaijan, and Georgia's financial and construction sectors. In general, China sees the Caucasus as a place for healthy competition with other external forces (Русакова, 2010, p. 189). On the other hand, Beijing is interested in South Caucasus from the perspective of creating a stable economic zone on the European markets' approaches. That can be explained by the possibility of expanding Chinese goods, investments, and labour in the future (Бабаян, 2011, p. 74).

Thus, in the context of strengthening China's position in the Black Sea region, Beijing is placing its main bet on its most competitive resource: economic influence with future intents to deploy a progressive expansion in domestic markets. By proposing the "One Belt, One Road" initiative China is increasing its economic presence and developing humanitarian ties. For example, Georgia signed a free trade agreement. Azerbaijan is interested in transport projects through the Caspian Sea. Armenia became the first Caucasian country to choose Chinese weapons over Russian ones (Роллан, 2018). China has once again demonstrated its pragmatism, preferring the railway project in Azerbaijan to the Armenian alternative: the first provides transit opportunities of 20 million tons per year, while the second, according to N. Rolland, "remains a fantasy" with the closure of the Turkish-Armenian border in 1993 (Роллан, 2018).

Economic interest helps to quickly forget some diplomatic tensions: at the beginning of 2013, the Chinese investments in Azerbaijan amounted to at least USD 1 billion. The Chinese, as elsewhere, scrupulously follow the logic of non-interference in the Internal Affairs of States in the region. In Azerbaijan and neighbouring countries, this is always perceived as a sign of respect. It should also be noted that investments were focused on Azerbaijani oil but was not limited by only this field: as in Armenia, the Chinese side uses their 
knowledge of thermal power plant technologies. As a result, China is presented in the region as a country with long-term strategies (Albert, 2018).

China has strengthened bilateral ties even with Georgia, although it is considered a pro-European and pro-Western country. China is expanding mutual relations with Georgia, primarily in the sphere of economy and agriculture. We can assume that in the framework of various projects aimed at delivering Chinese goods to Europe, China will try to take advantage of the country's favourable geostrategic position and use it as one of the transportation corridors. That is why the most significant Chinese investments are mostly concentrated in the transport sector and help Georgia with energy projects investments. Moreover, Chinese-Armenian relations are also reaching a new level. The bilateral cooperation is supported by the growing number of Chinese investments in Armenia, the Chinese experts' participation in various energy projects, and cooperation in the information technology, agriculture, and military spheres (“Китай активизируется”, 2019).

In Bulgaria and Romania, China focuses primarily on economic instruments that form the state's investment and financial attractiveness. China began to actively develop connections with these new EU Member States right after their reformation process. The revolutionary reforms in the former USSR's satellite countries gave freedom to entrepreneurship, denied Moscow's 'guardianship', and opened up these countries to the world market. Since 2011, China's interest in EU countries has grown significantly (Шишелина, 2019, p. 7). Bulgaria and Romania represented themselves as a convenient channel for trade and investment expansion in the EU space for China- as well as a 'testing ground' for working out mechanisms for such expansion and a potential tool for creating a favourable attitude to the Chinese initiatives in EU institutions. Over the past decade, China - EU trade in goods and services has grown about $60 \%$, to more than half a trillion EUR per year (Salem, 2020, p. 1).

Since 2011, the main economic instrument of the soft power concerning Albania, Bulgaria, and Romania has been the " $16+1$ " cooperation platform. It is unique for the PRC, since, as noted, China usually does not support a block or multilateral approach, but prefers trade and economic interaction at the bilateral level. The " $16+1$ " platform was created at China's initiative to develop political, economic, and cultural relations with 16 States of the Central-Eastern and South-Eastern Europe. In 2012 the first summit was held in Warsaw, which was attended by 11 member countries (Bulgaria, Romania, Croatia, Slovenia, Czech Republic, Slovakia, Latvia, Estonia, Lithuania, Hungary, and Poland) and five the EU candidate states (Albania, Bosnia and Herzegovina, Macedonia, Montenegro, and Serbia) (Oudenaren, 2018). The Chinese 
side proposed to the European partners the creation of a joint Secretariat, and in the future, an international organization, but the European participants preferred to hold regular summits based on an informal negotiating platform for cooperation. At the 2018 summit in Bulgaria, it was noted that the growth rate of trade transactions between China and the participating countries was higher than between China and the EU as a whole. This is primarily due to Albania's, Bulgaria's, and Romania's favourable location, as important transit routes pass through their territories, which in the future are necessary for China to implement the "One Belt, One Road" project. Cargo transportation is actively developing now for this purpose.

The railway network linked 43 Chinese cities to 42 cities in 14 European countries (Oudenaren, 2018). Considering the countries participating in the " $16+1$ " platform's financial and economic potential, they focused on specific cooperation areas. For example, Bulgaria hopes to intensify cooperation in the agricultural sector, while Romania hopes to implement long-term energy projects, particularly in the nuclear industry (Oudenaren, 2018). The Chinese leadership considers the railway connection to be an essential link for delivering goods to the European markets. To do this, it is planned to connect the "One Belt, One Road" initiative infrastructure with the TRANS - European transport network (a project to create a road, rail, air, and water transport connections) and to extend it to the Western Balkans (Rong, 2018). Besides this, China plans to build a network of new logistics infrastructure to develop cargo train services with rail connections to the EU countries. China is actively promoting the infrastructure development model, which leads to an increase in debt obligations under the " $16+1$ " platform. Beijing's offer is undoubtedly beneficial for some countries in the region. However, it has significant restrictions on low-interest rates and long-term Chinese loans, particularly attractive to governments with limited access to global financial resources and the EU funds. Chinese funds also do not include internal reforms' requirements which distinguish them from the World Bank's proposals, the IMF, and others. (Oudenaren, 2018).

The " $16+1$ " format achieved the most significant success directly within the framework of strengthening bilateral cross-governmental relations. The scale of China's activities concerning the EU newcomers is gradually moving into the political sphere and affecting strategic objects. In turn, it is calculated that economic dependence on China will also lead to political dependence. Beijing's closer ties with developing EU countries will influence EU policy and can be used to undermine the organization's common strategy.

The COVID-19 pandemic is an excellent example of Chinese economic diplomacy. Accused of trying to hide the essence of the issue, China has 
launched its 'mask diplomacy' to portray itself as a responsible international actor. China has started to assist in various forms due to its economic capabilities. President Xi Jinping promised that when the vaccine will be ready, it will become available for everybody. This was announced in contrast to Donald Trump's intention of purchasing a vaccine developed by Germany to use it in the US. According to Carminati, "we could say that countries who are receiving aid from China, will not forget it." (Carminati, 2020, p.1).

Moreover, the global supply chain disruption caused by the COVID-19 pandemic revealed the EU's deep dependence from China in many strategic areas. It highlighted the importance of extending European autonomy in areas that are not directly related to national security. The goal is to become self-sufficient in the medical and pharmaceutical industries and produce their computers, batteries, electric vehicles, and wind turbines (Salem, 2020, p. 2). Another goal is to protect the crucial technologies of European enterprises from Chinese investors. The acquisition of the European high-tech companies has enabled China's leading divisions to advance the Chinese technological leadership by gaining human capital experience. Thereby China facilitates the increase of its next-generation technologies and reinforces its position as an industrial leader (Salem, 2020, p. 2).

However, Beijing's economic expansion in Europe is causing the growth of negative attitudes in the EU. In recent years, the Europeans have even begun to criticize it openly. The main target for criticism is China's cooperation with the Eastern European EU Member States and candidate countries. In 2017, the German Foreign Minister Sigmar Gabriel called Beijing's policy in Europe a threat to the EU unity. He called for developing a unified EU strategy for the Chinese actions and determined the necessary response measures to prevent an internal split on the 'Chinese issue'. Gabriel's statements provoked a strong reaction from China. However, Beijing did not refute the desire to establish a dialogue with the Eastern European countries, bypassing Brussels. European politicians see a threat from Beijing and take appropriate measures. In the summer of 2017, the French President Emmanuel Macron called for stricter EU controls on foreign investment, especially for strategic areas. Emmanuel Macron directly pointed to the Chinese investment as the subject of the biggest concerns. He was supported by German Chancellor Angela Merkel and European Commission President Jean-Claude Juncker. The EU has started developing a common position on Chinese investments (“Китай активизируется”, 2019).

Consequently, China's economic activity in Bulgaria and Romania is objectively limited by its membership in the EU. There are differences and unresolved problems between Russia and China. Beijing is not satisfied with 
too high energy supply prices. The Russian side sees the activation of China's entry into the Black Sea region market as an economic threat because Russia could become not only an outback of Europe but also an outback of China. The PRC is well aware of the situation and manipulates the Black Sea region countries' interest in creating a new support point for its global policy. On this basis, China is pragmatically considering the space between the Black Sea and Central Asia as a potentially profitable investment of its political and economic resources.

\section{China's humanitarian cooperation with the Black Sea Region}

The effectiveness of the Chinese soft power on the Russian society can be judged by the example of the comparative dynamics of the emotional perception of China and other countries in the world. In the 1990s, Russian views were entirely focused on the West. The Eastern countries did not arouse in them any particular interest- but after 2001, the situation began to change rapidly (Галенович, 2010).

According to various sociological studies, China is the biggest supporter of Russian culture. In 2014, the Russian surveys showed that $65 \%$ of Russians had positive feelings toward China, while negative responses were only around 14\%. In the following year, the Pew Centre survey of 2015 showed that $51 \%$ of Russians have positive feelings toward China (and $37 \%$ negative1y). This significantly differs from the 2014 results. However, this is still one of the highest results for the Russian Federation's image worldwide. Russians continue to remember the Soviet-Chinese friendship, and the struggle against the Western countries only facilitates the positive attitude (Laruelle, \& Luo, 2020, p. 1).

According to Laruelle and Luo, "thirty years after the collapse of the Soviet Union, the Communist Party of China (CPC) and the Chinese nationalists are still traumatized by the former USSR's disappearance. They interpret this event as a geopolitical tragedy that the party of modern China should avoid." (2020, p. 2). At the same time, President Xi Jinping, who came to power in 2013, said that "no one could resist the collapse of the USSR in 1991" (Laruelle, \& Luo, 2020, p. 2). The CPC's "People Daily" regularly highlights Vladimir Putin as an example of "a Russian patriot working hard to promote his country's culture, history, and military strength". According to Dr. Li Ling of the Academy of Social Sciences, the CPC should learn from the Putin administration in promoting "militaristic patriotic education, citizens" willingness to sacrifice for their nation, and pride for their national identity." (Laruelle, \& Luo, 2020, p. 2).

In the Black Sea Region, Russia is the only country other than China that can use its soft power (Nye, 2013). At the same time, Russia's capabili- 
ties in this regard are approximately equal to those of China. According to the global soft power rating of 2018 compiled by the British Agency "Portland Communications' China ranked the 27th and Russia the 28th ("Global ranking of soft power", 2018).

Nevertheless, such deep cultural interaction with the Russian Federation is an exception for the Black Sea Region's Chinese strategy. In all other countries, the Confucius Institute is the main instrument for implementing China's humanitarian policy.

It is difficult to separate the Chinese humanitarian strategy from its economic strategy. Only a few countries in the world have sufficient financial resources to open cultural centres worldwide and promote exchanges for mutual understanding. Currently, there are more than 500 Confucius Institutes in different countries. The Confucius Institute lays the necessary foundation for the further establishment of influence networks. Their official task is to teach Chinese, particularly to local elites, who are called upon to participate in future exchanges with China. However, in reality, they also act as agents of influence, following the Chinese Communist party's line and protecting the Chinese state's interests. The Confucius Institute program began in 2004. At first, it was aimed at the Central Asia countries, the post-Soviet states, and Eastern Europe; the first Confucius Institute in the Post-Soviet region was opened in Belarus in 2006 (Яньдун, 2011, p. 10). Some Confucius Institutes were closed due to the fear of interfering with universities' academic freedom. Nevertheless, most countries welcome them, primarily since they teach excellent Chinese and offer scholarships to study in China.

The Chinese political leadership believes that the Confucius Institute's establishment is a powerful channel for promoting cultural exchange between China and foreign countries (Цзиньпин, 2017). Therefore, these institutions can be called an essential part of the PRC's external propaganda.

Russia surpassed all European countries in the number of the Confucius Institutes (except only for Great Britain) (Ягья, \& Минфу, 2015, p. 85). It is not only a way of creating a public attitude of always looking back on China, which is continuously present in political life as a new stable stereotype but also provides stable and consistent support for Russia's independent foreign policy towards the West (Edney, 2012, p. 910).

The Confucius Institutes are equally successful in Albania, Bulgaria, and Romania. They teach Chinese, make exhibitions, prepare concerts, and conduct many other cultural projects (Rong, 2018). The expansion of academic contacts is also noted: exchange programs of scientists and teachers and international students' training in Chinese universities (Mattern, 2005, p. 601). 
To promote the Chinese culture and the Chinese language, create and maintain a positive image of China in the Caucasus, Beijing is actively working at cultural diplomacy. In addition to the established the Confucius institutes (in Yerevan in 2009, in Tbilisi in 2010 and in Baku in 2011), Chinese language schools and cultural exchange programs between universities were created (Цзиньпин, 2014, p. 47). The Georgian-Chinese cultural centre "Silk Road", founded in 1992, is still playing an essential role, as the centre's primary goal is to develop and deepen cultural and economic ties (Бабаян, 2011).

In addition to the Confucius Institutes, the Academy of Social Sciences (the Chinese Policy Analytic Centre affiliated with the State Council of China) offers an additional interaction format. Special attention is paid to scientific and technical contacts. In 2015 The Academy of Social Sciences of the People's Republic of China took the initiative to create "Think Tanks Network" within the " $16+1$ " cooperation framework. These intellectual centres" main task was determined by China's desire to gain access to Eastern European countries' intellectual capital. In April 2017, the independent Think Tank, "China-CEE Institute", was established (Шишелина, 2019, p. 9).

The tools of humanitarian power include not only an attractive educational system but also scientific and technical activities (Цзайци, 2009, p. 150). The degree of development of the infrastructure of humanitarian cooperation between the PRC and the region's countries could be shown using the example of the Russian Federation: Russian-Chinese society; Russian-Chinese Foundation for Culture and Education Development; Russian-Chinese Committee for Friendship, Peace and Development; Russian Cultural Centre in Beijing; Chinese Cultural Centre in Moscow (Карпов, 2013).

China's other comprehensive project is the "One Belt, One Road" initiative. This is an ambitious plan to connect the whole world to the land of the ancient 'Middle Kingdom', which will be profitable and useful for all involved partners. One of the main principles is the unity of different communities and cultures (Carminati, 2020, p. 1). It should be noted that in comparison with the Russian Federation or European countries, the Caucasian republics were less critical toward China until they became an essential direction of the Chinese "One Belt, One Road" initiative.

Among the additional tools of the Chinese policy is the promotion of the famous brands and leading Chinese enterprises (Xiaomi, Huawei, Aliexpress, and Haier), which are an essential part of China's economic expansion in Europe. China has introduced the China Union Pay payment system in the telecommunications sector, which means a new way of international money transfers to Europe that the US cannot block (Rong, 2018). 
Countries that have received generous and timely assistance in times of need, young people who get access to the educational and professional opportunities offered by the Confucius Institutes, and economic benefits from a high-speed railway or a new $5 \mathrm{G}$ network (or even a combination of all these) are indeed developing an extremely positive attitude towards China. This is especially true if events benefit both the population and political leaders (Carminati, 2020, p. 2).

Many experts believe that China has only started to develop its national concept of different approaches toward other cultures. However, propaganda measures are not the exclusive tool of authoritarian actors. Even if Beijing's intentions are not consistently honest and transparent, it is clear that China knows how to adapt its strategies to each country.

\section{Conclusions and forecasts}

In summing up the PRC's success in the Black Sea Region, we should highlight the " $16+1$ " cooperation project, which significantly strengthened China's ties with Albania, Bulgaria, and Romania. Among the PRC's failures, it should be noted that China's economic expansion in Europe is causing growing dissatisfaction within the EU. Therefore, the EU has begun to develop a common position on Chinese investment.

At the global level, China is interested in creating an alliance with Russia, Turkey, Iran, and Pakistan. The introduction of harsh economic sanctions by the United States against Russia and Iran has forced them to knock on Beijing's doors. If the United States and its allies jointly try to fight back against such an alliance, the world may see the most pessimistic scenario - a new Cold War or even a nuclear war. The modern world seems unbalanced and multipolar, and therefore, the probability of war is becoming more likely (Raja, \& Dar, 2020).

The realistic scenario assumes a further tilt of the PRC toward the Russian Federation as an actor, aiming to create a centre of power, in opposition to the 'collective West' concept. However, Moscow's ambitions are not accompanied by appropriate tools and resources. Hence, an alliance with China can lead to a bandwagoning of the Russian Federation and even to its transition to the position of a 'junior' partner. The strategic value of Russia for the Chinese leadership should not be overestimated. It has its borders, including the issues connected with Ukraine (particularly Crimea), investment cooperation, and the unrecognized republics of Transcaucasia (Abkhazia and South Ossetia). It is also still unclear where Russia's place is in the Chinese "One Belt, One Road". Russia supports the "One Belt, One Road" initiative, hoping that its transcontinental transport corridors will become an essential part of the new international economic transit system. 
A favourable scenario for China is a continuation of its already successful policy in the Black Sea Region. Its main foreign policy instruments are based on each country's specific traits in the Black Sea Region to make the most significant benefits. Thus, concerning the European countries, the focus is placed on economic instruments and the Caucasian region- on diplomacy. Ukraine, Moldova, Albania, Bulgaria, and Romania see the 'Chinese factor' as a way to overcome the economic gap between themselves and their Western partners. There has been an increase in economic, political, and cultural cooperation in recent years, where the Chinese side played an important role. The PRC favours the countries that demonstrate a stable political environment, a developed market and a cheap and educated labour force. All these factors attract Chinese businessmen and give hope for the effective implementation of the "One Belt, One Road" initiative. Moldova and Ukraine are losing in this sense to Bulgaria and Romania. China's policy is marked by numerous educational exchange programs, cultural forums, and increased tourism circulation within the " $16+1$ " cooperation platform framework. Thus, China influences the entire European framework, strengthening its position in the global competition for raw materials and sales of its products, especially in confrontation with the United States. Although China has relatively little historical experience in geopolitical relations with the Caucasian region states, China intends to change this (Цзиньпин, 2014). China is able to strengthening ties with these three countries without eliciting dissatisfaction from regional players such as the Russian Federation and Turkey. Beijing does not interfere in states' internal affairs, which is perceived by them as a sign of respect and inspires them to pursue a more comprehensive cooperation. Today and in the near future, Beijing will primarily rely on its most competitive external resource: economic power.

\section{References}

1. 20 років стратегічного партнерства Пекіна і Києва. Роль України у військовій модернізації Китаю. (2014). Retrieved from http://mil.news.sina.com. cn/2014-01-15/0935760158.html

2. Бабаян, Д. С. (2011). Роль и место Южного Кавказа в геополитической повестке Китайской Народной Республики. 21-й BEK, 2 (18), 66-92. Retrieved from https://cyberleninka.ru/article/n/rol-i-mesto-yuzhnogokavkaza-v-geopoliticheskoy-povestke-kitayskoy-narodnoy-respubliki/viewer

3. Газпром возобновил поставки газа в Китай по Силе Сибири-1. (2020, 1 апреля). Neftegaz.RU. Retrieved from https://neftegaz.ru/news/ Trading/539674-gazprom-vozobnovil-postavki-gaza-v-kitay-po-sile-sibiri-1/

4. Галенович, Ю. М. (2010). Взгляд на Россию из Китая. Прошлое и настоящее России и наших отнотений с Китаем в трактовке китайских ученых. Москва: Время. 
5. Голова КНР Сі Цзіньпін визначив основні перспективні сфери співробітництва з Туреччиною. (2015, 31 липня). CRIonline. Retrieved from http:// ukrainian.cri.cn/841/2015/07/31/2s40865.htm

6. Давыдов, Ю. П. (2004). Понятие «жесткой» и «мягкой» силы в теории международных отношений. Международные процессы, 4, 69-80.

7. Договор о добрососедстве, дружбе и сотрудничестве между Российской Федерацией и Китайской Народной Республикой от 16 июля 2001 года. Президент России. Retrieved from http://www.kremlin.ru/supplement/3418

8. Карпов, М. В. (2013). Современная Россия в поле «мягкой сильл» Китая: некоторые аспекты теории и практики взаимодействия. Страны СНГ и Балтии в глобальной политике Китая. Москва: РИСИ.

9. Китай активизируется в Европе. (2019, Март 24). Информационное сопротивление. Правда належсить вільним. Retrieved from https://sprotyv. info/news/kitaj-aktiviziruetsya-v-evrope

10. Китай недоволен вмешательством Запада в дела Украины. (2013, Декабрь 13). Зеркало недели. Retrieved from http://zn.ua/WORLD/kitay-nedovolenvmeshatelstvom-zapada-v-dela-ukrainy-134976_html

11. Клусман, У. (2014, Март 21). Тень Китая нависла над Украиной: Пекин поддерживает Москву. InoPressa. Retrieved from https://www.inopressa.ru/ article/21Mar2014/spiegel/china.html

12. Концепция внешней политики Российской Федерации. (2019). Министерство иностранных дел РФ. Retrieved from http://www.mid.ru/brp_4. nsf/0/6D84DDEDEDBF7DA644257B160051BF7F

13. Корсунський, С. (2020, 18 серпня). Китай вибирає стратегію відносин зі Сполученими Штатами. Дзеркало тижня. Retrieved from https://zn.ua/ ukr/international/seredinnij-shljakh-skhodu.html

14. Леонова, О. Г. (2013). Мягкая сила - ресурс внешней политики государства. Обозреватель-Observer, 4, 27-40.

15. Мавріна, О. С. (2012). Стратегічне партнерство в зовнішньополітичній практиці Туреччини. Сходознавство, 59, 48-81. Retrieved from http:// nbuv.gov.ua/UJRN/Skhodoz_2012_59_8

16. Очередная пресс-конференция у официального представителя МИД КНР Хуа Чуньин. (2014, 25 февраля). Ministry of Foreign Affairs of the People's Republic of China. Retrieved from http://www.fmprc.gov.cn/rus/ $\mathrm{xwfw} / \mathrm{fyrth} / \mathrm{lxjzhzhdh/t1133381.shtml}$

17. Покась, М. С. (2017). Україно-китайські відносини. У І. М. Коваль, О. І. Брусиловська, В. А. Дубовик (Ред.). Стратегічна культура та зовнішня політика України, 138-153. Одеса: Одеський національний університет імені I. I. Мечникова.

18. Роллан, Н. (2018). Влияние Китая в странах Восточной Европы и Южного Кавказа. Notes de lIfri Russie.Nei.Visions, 112. Retrieved from https://www. ifri.org/sites/default/files/atoms/files/vliyanie_kitaya_v_stranah_vostochnoy_ evropy_i_yuzhnogo_kavkaza.pdf

19. Русакова, О. Ф. (2010). Концепт «мягкой» силы (soft power) в современной политической философии. Научный ежегодник Института философии и права Уральского отделения РА, 10, 173-192.

20. Терещенко, Ю. (2014, Март 28). Потребности Вооруженных сил - глав- 
ный приоритет «Укроборонпрома». Зеркало недели. Retrieved from http://gazeta.zn.ua/internal/potrebnosti-vooruzhennyh-sil-glavnyy-prioritetukroboronproma-_html

21. Товарооборот России с Китаем растёт за счёт импорта. (2020, Апрель 14). EurAsiaDaily. Retrieved from https://eadaily.com/ru/news/2020/04/14/ tovarooborot-rossii-s-kitaem-rastyot-za-schyot-importa

22. Торговельно-економічне співробітництво між Україною та Китаєм. (2020, Серпень 5). Сайт Посольства Украӥни в Китайській Народній Республічі та в Монголії (за сумісництвом). Retrieved from https://china. mfa.gov.ua/spivrobitnictvo/186-torgovelyno-jekonomichne-spivrobitnictvomizh-ukrajinoju-ta-kitajem

23. Тымчук, Д. (2017). Украина-Китай: бег по лезвию «технологической бритвы». Flot. Retrieved from http://flot2017.com/posts/new/ukrainakitaj_ beg_po_lezviju_tehnologicheskoj_britvy_

24. Цзайци, Л. (2009). «Мягкая сила» в стратегии развития Китая. Политические исследования, 4, 149-155.

25. Цзиньпин, С. (2014). Великое возрождение китайской нации - величайшая мечта китайской нации с начала нового времени. $O$ государственном управлении, 47-50. Пекин: Издательство литературы на иностранных языках.

26. Цзиньпин, С. (2017). Полный текст доклада, с которым выступил Си Цзиньпин на 19-м съезде КПК. 19-й Всекитайский съезд КПК. Retrieved from http://russian.news.cn/2017-11/03/c_136726299.htm

27. Шевырев, И. (2011). Украина и Китай: 20 лет вместе. Кіевскій телеграфъ. Retrieved from http://telegrafua.com/country/12879/

28. Шишелина, Л. Н. (2019). Центральная Европа в стратегии Китая. Научно-аналитический Вестник Института Европь РАН, 2. Retrieved from https://cyberleninka.ru/article/n/tsentralnaya-evropa-v-strategii-kitaya

29. Ягья В. С., \& Минфу, Л. (2015). Институт Конфуция как фактор «мягкой силы» во внешней политике КНР в XXI веке. Международная жизнь, 7 , 84-93.

30. Яньдун, Л. (2011). Совместная работа для устойчивого развития институтов Конфуция: Программная речь на V съезде Институтов Конфуция. Институт Конфуция, 1 (4), 10 (русско-китайская версия).

31. Albert, E. (2018, February 9). China's Big Bet on Soft Power. Council on Foreign Relations. Retrieved from https://www.cfr.org/backgrounder/chinasbig-bet-soft-power

32. Barnett, M., \& Duvall, R. (2005). Power in International Politics. International Organization, 59 (1), 39-75. Retrieved from https://www.cambridge.org/ core/journals/international-organization/article/power-in-international-politics/F5F3C74D30A12A5C4CC9B4EFEA152967

33. Callahan, W., \& Barabantseva, E. (Eds.). (2012). China Orders the World: Normative Soft Power and Foreign Policy. Johns Hopkins University Press.

34. Carminati, D. (2020, July 3). The State of China's Soft Power in 2020. E-International Relations. Retrieved from https://www.e-ir.info/2020/07/03/thestate-of-chinas-soft-power-in-2020/ 
35. China Makes Proposals on Political Solution to Ukraine Crisis. (2014, March 16). Ecns.cn. Retrieved from http://www.ecns.cn/2014/03-16/105061.shtml

36. Chinese State Councilor, U.S. National Security Advisor Discuss Ukraine over Phone. (2014, March 6). Global Times. Retrieved from http://www. globaltimes.cn/content/846662.shtml

37. Edney, K. (2012). Soft power and the Chinese propaganda system. Journal of Contemporary China, 21 (78), 899-914.

38. Global Ranking of Soft Power. (2018). Portland Communications. Retrieved from https://portland-communications.com/publications/a-global-ranking-of-soft-power-2018/

39. Hongyi, L., \& Yiyi, L. (Eds.). (2012). China's Soft Power and International Relations. London and New York, NY: Routledge. Retrieved from https:// www.researchgate.net/publication/276526519_Hongyi_Lai_and_Yiyi_Lu_ eds_China's_Soft_Power_and_International_Relations

40. Laruelle, M., \& Luo, Wei (Josh) (2020). Soviet Legacy as Soft Power. Chinese Reception of Russian Political and Cultural Influence. PONARS Eurasia, Policy Memo 667. Retrieved from https://www.ponarseurasia.org/memo/soviet-legacy-soft-power-chinese-reception-russian-influence

41. Mattern, J. (2005). Why "Soft Power" Isn't So Soft: Representational Force and the Sociolinguistic Construction of Attraction in World Politics. Millenium - Journal of International Studies, 33 (3), 583-611.

42. Nye, J. (2004). Soft Power. The means to success in world politics. N.Y.: Public Affairs.

43. Nye, J. (2011). The Future of Power. N.Y.: Public Affairs.

44. Nye, J. (2013, April 29). What China and Russia Don't Get About Soft Power. Foreign policy. Retrieved from https://foreignpolicy.com/2013/04/29/whatchina-and-russia-dont-get-about-soft-power/

45. Oudenaren, J. (2018, September 4). Why China Is Wooing Eastern and Central Europe. The National Interest. Retrieved from https://nationalinterest.org/ feature/why-china-wooing-eastern-and-central-europe-30492

46. Palanisami, R. (2020, August 10). Opinion - Making Sense of China's 'Wolf Warrior' Diplomacy. E-International Relations. Retrieved from https://www.e-ir.info/2020/08/10/opinion-making-sense-of-chinas-wolf-warrior-diplomacy/

47. Raja, R., \& Dar, Z. A. (2020, August 9). Asian Security amid China's Dominance. E-International Relations. Retrieved from https://www.e-ir. info/2020/08/09/asian-security-amid-chinas-dominance/

48. Rong, G. (2018, April 25). China launches «China-CEE Institute» think tank in Hungary. Official website for China Global Television Network (CTGN LIVE). Retrieved from https://news.cgtn.com/news/3d4d444f78597a4d/ share_p.html

49. Salem, K. (2020, August 8). Opinion - Europe and China's Growing Assertiveness. E-International Relations. Retrieved from https://www.e-ir. info/2020/08/08/opinion-europe-and-chinas-growing-assertiveness/

50. Wu, Yipin. (2020). Dynamics of policy change in authoritarian countries: a multiple-case study on China. Journal of Public Policy, 40, 236-258. DOI: https://doi.org/10.1017/S0143814X18000351 


\section{CHAPTER 8 \\ THE STATES OF THE BLACK SEA REGION IN JAPAN'S FOREIGN POLICY: HISTORY AND MODERNITY}

(Violetta Udovik)

\section{Introduction}

Japan is a global power, an active member of the United Nations and the G7, the world's third largest economy, an international donor, a US military ally, a partner of Europe, and a leader in East Asia. These are the main attributes that come to mind when we talk about Japan: its most important achievements and activities in the international arena. At the same time, little is known about Japan's relations with the countries of the Black Sea region. However, despite the remoteness of the Land of the Rising Sun from this geopolitically important region and the fact that it did not appear in Japan's foreign policy strategy until the 21 st century, the history of relations between Japan and the Black Sea states dates back to the mid- $19^{\text {th }}$ and early 20 th century.

In 1855, the Shimoda Treaty was signed between Japan and the Russian Empire. 1882 is considered the year of friendship between Serbia and Japan, since this is the year in which the first diplomatic correspondence between the Serbian King Milan Obrenović and Emperor Meiji took place. Japanese-Turkish relations are based not only on contacts during the era of the Ottoman Empire, such as the visit of Japanese Prince Komatsu-no-miya Akihito to Constantinople in 1887, but also on the help provided by the Japanese government and the subjects of the Japanese Empire after the sinking of the frigate "Ertugrul" off the coast of Japan in 1890 - an act of assistance which became a symbol of friendship between the two nations.

Japan's diplomatic relations with Greece were established through the signing of the Treaty of Friendship, Trade and Shipping in 1899. In 1902, Japan established its first diplomatic contacts with Romania, by virtue of which both countries opened diplomatic missions - Romania in Tokyo in 1921, and Japan in Bucharest in 1922. Japan de facto recognized the independence of the Georgian, Azerbaijani and Armenian republics in 1920, and the Armenian national Diana Abgar was appointed Honorary Consul in the Japanese state. In 1939, Japan and Bulgaria established mutual diplomatic missions.

Ukrainian-Japanese contacts were developed in three directions. First, in 1902-1904, 1905-1908 and 1925-1937, the Japanese consulate was in op- 
eration in Odesa. Second, Ukrainian contacts with the Japanese in the Far East were developed in the first half of the 20th century. They took place in the Ukrainian colony "Zeleny Klyn" or "Green Ukraine", which consisted of the area between the Amur River and the sea, and in Manchuria (modern China). Third, it is known that, in 1917, the Embassy of Japan in Petrograd sent diplomatic and military missions to Kyiv and, in 1920, correspondence was conducted between representatives of the Ukrainian People's Republic and Japanese diplomats in Europe.

Nowadays, Japan is interested in building cooperation with the Black Sea region for a number of objective reasons. First, Japan is interested in strategic geographical position of the Black Sea that serves as a crossroads connecting Europe, Central Asia and the Middle East. Politically, the Black Sea region provides opportunities for cooperation between the North Atlantic Treaty Organization led by the United States, which is Japan's main security ally, and Russia, Japan's neighbour, relations with which involve a number of unresolved issues. In terms of security, Japan is committed to non-recognition of the change in the status quo by the use of force, and calls for compliance with the rules and principles of international law. As an island nation, it has also been making consistent efforts to ensure maritime security and naval freedom in all the seas, including the Black Sea and the Sea of Azov. With regard to economics, the Black Sea Economic Cooperation group represents an attractive market of 333 million consumers and a combined GDP of 2.8 trillion USD, accounting for $14 \%$ of Europe's economy and $4 \%$ of the world's economy (Market Intelligence, 2018).

\section{Japan's foreign policy in the post-bipolar period: the transformation into a "normal country"}

An important precondition for the development of Japan's relations with the states of the Black Sea region was the general activation of its foreign policy. After the collapse of the bipolar system of international relations, Japan embarked on a comprehensive restructuring of its foreign policy strategy in order to become a "normal country". In this context, Japan's "abnormality" reflects the impossibility of making certain political decisions due to the limitations of the role and functions of its military forces, bureaucratic constraints, the spread of anti-militarism, difficulties in relations with other Asian countries, US security guarantees, etc. (Soeya, Welch, \& Tadokoro, 2011, p. 4-7).

Japanese researcher K. Iwanaga points out that the evolution of Japan's foreign policy in the post-bipolar period has been characterized as a "modified continuity". He draws a parallel between Japan and Germany, which 
overtook Japan and became a "normal country" before the 1990s by virtue of its involvement in operations in the Balkans and Kosovo. Iwanaga notes that, after the end of the Cold War, Japan was able to shift from pursuing "checkbook diplomacy", which consists of providing economic assistance to other countries with the aim of strengthening influence in the international arena, to participating in non-combat operations in Asia. At the same time, the aforementioned researcher believes that this is not enough to transform Japan into a "normal country" and emphasizes the need to formulate a new major Japanese foreign policy strategy (Iwanaga, 2011, p. 59-61).

The central event in this regard can be considered the adoption of the National Security Strategy in 2013 by the Japanese Prime Minister Abe Shinzo, according to which the fundamental principle of Japan's national security is a "Proactive Contribution to Peace" based on the principles of international cooperation. Under this strategy, Japan is to work to "improve the global security environment and build a peaceful, stable and prosperous international community by strengthening the international order based on universal values and rules, and by playing a leading role in the settlement of disputes" (National Security Strategy, 2013). It was this approach that ensured Japan's involvement in the resolution of the issue of the occupation of Crimea, increased its political presence in the Black Sea region, and helped strengthen Ukrainian-Japanese relations.

Given that the Organization of the Black Sea Economic Cooperation (BSEC) is heterogeneous and consists of members from the European Union, NATO, OSCE, CIS, GUAM, Eastern Partnership, etc., Japan had been focusing on development of bilateral relations with BSEC countries and became engaged with the region as a whole only at the beginning of the 21 st century.

In this context, it should be noted that Japan became the first Asian country invited to attend the Conference on Security and Cooperation in Europe - a forerunner of the Organization for Security and Cooperation in Europe. In 1996, Japan became an observer of the Council of Europe and an active member of the Asia-Europe Meeting (ASEM). Relations between Japan and the EU have developed gradually based on such key documents as the Joint Declaration of 1991, the Action Plan for EU-Japan Cooperation of 2001, Japan-EU Strategic Partnership Agreement of 2018 and the EU-Japan Economic Partnership Agreement that took effect in 2019. Additionally, Japan has been actively promoting relations with European countries through such micro-regional frameworks as the "Vishegrad Four ${ }^{1}$ plus Japan" and the "Nordic-Baltic Eight ${ }^{2}$ plus Japan" which, along with the G7, have become im-

\footnotetext{
1 Includes the Czech Republic, Hungary, Poland and Slovakia.

2 Includes Denmark, Finland, Iceland, Norway, Estonia, Latvia and Lithuania.
} 
portant platforms for discussions on the situation in Ukraine. As for relations with the NATO, Japan has developed cooperation with this organization as a "partner across the globe" based on the Joint Political Declaration of 2013, as well as the Individual Partnership and Cooperation Programme of 2014.

The European factor has had a positive impact on the development of relations between Japan and the BSEC member states. As a confirmation of this, it should be noted that the first visit of the Minister for Foreign Affairs of Japan to Romania and Bulgaria took place after the accession of those countries to the EU in 2007. In addition, the signing of the EU-Ukraine Association Agreement in 2014 facilitated a more active entry of Japanese companies into the Ukrainian market. The development of Japan's relations with the NATO and the EU in the direction of a strategic partnership also highlighted the need for a greater Japanese involvement in the Black Sea region, the stability of which is an important element in ensuring peace and security in Europe.

The collapse of the Soviet Union greatly influenced Japan's foreign policy. First, it prompted the Japanese government to actively seek a resolution to the issue of the Northern Territories, or the Kuril islands ${ }^{3}$, and the signing of a peace treaty with Russia. Second, it created an opportunity for Japan to establish relations with the newly independent states including the BSEC members Ukraine, Armenia, Azerbaijan, Georgia and Moldova. Third, Japan became involved in international efforts aimed at providing assistance to the post-Soviet countries, consisting of humanitarian, financial and technical support. Finally, Japan has played an important role in the process of eliminating nuclear weapons in Ukraine, Belarus and Kazakhstan, as well as nuclear waste in Russia.

In the 1990s, a strategy for the development of relations with post-Soviet countries was defined, which consisted of: 1) developing political dialogue and humanitarian exchanges; 2) providing official development assistance and humanitarian assistance to support the countries of the region in building state institutions, democracy and a market economy; 3) encouraging economic cooperation; and 4) promoting mutual understanding and cultural exchange (Uyama, Len, \& Hirose, 2009, p. 5-6).

Based on the abovementioned strategy, on December 28, 1991, Japan recognized all the newly independent states, with the exception of Georgia (its independence was recognized in April of 1992). In the period from January to September of 1992, diplomatic relations were established with the following states: on January 26: Ukraine, Belarus, Kazakhstan, Kyrgyzstan,

\footnotetext{
${ }^{3}$ Four islands located off the northeast coast of Hokkaido in Japan, namely Habomai, Shikotan, Kunashiri and Etorofu.
} 
Tajikistan, Uzbekistan; on March 16: Moldova; on April 22: Turkmenistan; on August 3: Georgia; and on September 7: Azerbaijan and Armenia.

In January of 1993, Japanese embassies were opened in the most populated countries of the region - Ukraine (where the Embassy of Japan also covered the Republic of Moldova), Belarus, Kazakhstan and Uzbekistan. In April of 1993, a Division of the Commonwealth of Independent States was established in the Ministry of Foreign Affairs of Japan (same as above, p. 4). In 2004, this division was reorganized into the Central Asia and Caucasus Division and the Central and South Eastern Europe Division, which includes Ukraine (Gaimusho Soshikirei, 2000).

With regard to the political dimension, Japan focused on establishing closer ties with the Central Asian states. Japan's main interest in relations with these countries was economic. Given the rich oil and gas resources of the Caspian Sea, Japan has set a course on energy diversification, relying on new sources from Central Asia, due to Japan's 94\% dependence on natural resource imports (Japan's Energy Supply Situation and Basic Policy, 2015). Building relations with the Central Asian republics was also considered necessary to ensure a balance of power while regional initiatives were being promoted by Russia and China. In addition, the stability and democratic development of the region were seen as an element in the stabilization of North Asia as a whole.

For the aforementioned reasons, Japan ensured an active political dialogue with the Central Asian republics after the collapse of the USSR. In 1992, Japan's Minister for Foreign Affairs M. Watanabe visited Kazakhstan and Kyrgyzstan; and in 1993-1994, the presidents of Kyrgyzstan, Kazakhstan and Uzbekistan paid visits to Japan. In 1993, Japan began providing financial assistance to the Central Asian republics.

In 1997, Japan adopted the foreign policy concept known as "Eurasian Diplomacy", the main purpose of which was to put forth a strategy towards Russia, China and the Silk Road region that encompassed the former Soviet republics of Central Asia and the Caucasus. The Japanese Prime Minister Hashimoto Ryutaro sought opportunities to build a more multilateral approach to the Eurasian continent while maintaining close bilateral relations with the United States.

The next step was the establishment in 2004 of the multilateral regional dialogue "Central Asia plus Japan", which aimed to strengthen cooperation between Japan and the Central Asian states, as well as to expand the dialogue between these republics. It is believed that one of the stimuli for the institutionalization of Japan's relations with Central Asia was the establishment, in 2001, of the Shanghai Cooperation Organization, which includes China, 
Russia, Kazakhstan, Kyrgyzstan, Tajikistan and Uzbekistan. The importance of Central Asia for Japan was also reflected in the amount of aid it supplied: as of 2014, the region had received more than 5 billion USD.

In 2015, S. Abe visited Mongolia, Kazakhstan, Uzbekistan, Tajikistan, Turkmenistan and Kyrgyzstan (the latter three for the first time), demonstrating an unprecedented level of Japanese interest in the region. During these visits, S. Abe announced 24 billion USD of assistance to Central Asia (Udovik, 2016, p. 58-60).

The "Arc of Freedom and Prosperity" and "Japan - Black Sea Area
Dialogue"
The expansion of Japan's diplomacy to the West was not limited to the introduction of "Eurasian diplomacy" or "Silk Road Diplomacy", which included Russia, China and Central Asia. The next step was the development of relations with the Black Sea region and Eastern Europe, including Ukraine, which became the object of a new Japanese foreign policy initiative called the "Arc of Freedom and Prosperity".

The concept of the "Arc of Freedom and Prosperity" and "value-oriented diplomacy" was first put forth in a speech by Japan's Foreign Minister Aso Taro in 2006. According to T. Aso, "value-oriented diplomacy" means taking into account such "universal values" as democracy, freedom, human rights, the rule of law and market economy while engaging in foreign policy. The Minister proposed the creation of an "Arc of Freedom and Prosperity" consisting of young democracies located in the "outer rim of Eurasia" and proclaimed this idea as a new principle of Japan's foreign policy (Speech by Mr. Taro Aso, Minister for Foreign Affairs, 2006). The "Arc of Freedom and Prosperity" included such organizations and countries as "CLV" (Cambodia, Laos and Vietnam), India, Afghanistan, the Central Asian countries (Kazakhstan, Uzbekistan, Kyrgyzstan, Turkmenistan, Tajikistan), the Middle East, the GUAM countries (Georgia, Ukraine, Azerbaijan, Moldova), the Community of Democratic Choice (Ukraine, Moldova, Latvia, Lithuania, Estonia, Slovenia, Macedonia, Romania, Georgia), the Visegrad Four (Czech Republic, Hungary, Poland, Slovakia) and the Baltic States (Latvia, Lithuania and Estonia).

The importance of this initiative lies in the fact that it was the first time the Black Sea, Ukraine, GUAM, and the Community of Democratic Choice (CDC) were mentioned in the foreign policy concept of Japan. In the process of developing this concept, it was initially intended to be applied only to the countries of the Black Sea region, but later its coverage was extended to the entire Eurasian continent (Mutsushika, 2017, p. 20-21). However, despite the wide geographical range of this concept, T. Aso stressed the need to ensure 
stability in the GUAM countries and paid close attention to the efforts of Ukraine, Georgia, Lithuania and Romania in the formation of CDC which, according to the Minister, "promotes formation of stronger roots for democracy in the Baltic - Black Sea region as well as in the Caspian Sea area". He also called for intensified contacts between Japan and members of the CDC and GUAM, emphasizing that "it is best to pursue cooperation with countries that are capable of partnering with Japan" (Speech by Mr. Taro Aso, Minister for Foreign Affairs, 2006).

The "Arc of Freedom and Prosperity" became the fourth principle of Japan's foreign policy, complementing the principles of "international cooperation through the United Nations", "cooperation with the liberal world" and "maintaining its position as an Asian nation", which were proclaimed in 1957. By virtue of this initiative, Japan was not only able to strengthen relations with countries that shared universal values, but also to expand its diplomatic horizons by intensifying relations with new regions, in particular the Black Sea area.

Many Japanese experts gave a positive evaluation to the introduction of value-oriented diplomacy. According to Japanese diplomat N. Kanehara and Osaka University professor K. Sakamoto, the "Arc of Freedom and Prosperity" confirmed Japan's success in helping Eastern Europe and Southeast Asia to develop democracies and market economies. It is noted that most Eastern European countries are now stable democracies and members of NATO and the EU, and that they are willing to cooperate with Japan - a fact that can be considered an example of the success of Japan's post-war diplomacy (Kanehara, \& Sakamoto, 2007, p. 23).

S. Mutsushika, a Japanese specialist in Black Sea regional studies, considers the proclamation of the "Arc of Freedom and Prosperity" a "revolution" in Japanese diplomacy. According to Mutsushika, this concept is a step towards the globalization of Japan's foreign policy, which will reduce the gap between the goals of its diplomacy and its responsibility for international affairs. He believes that the "Arc of Freedom and Prosperity" has confirmed Japan's intention to take responsibility for global security - an appropriate position for a country aspiring to become a permanent member of the UN Security Council. Professor Mutsushika also states that by virtue of cooperation with the EU and the NATO in building relations with Central Asia and the Black Sea region, Japan will have more room for maneuver in relations with Russia and China (Mutsushika, 2007, p. 2-4).

The Japanese Ambassador to Ukraine Mabuchi Matsuo (2005-2008) also praised this initiative, claiming that it altered Ukraine's position in Japan's foreign policy. In his opinion, the proclamation of this initiative gave 
Ukraine an opportunity to become a leader in the Baltic, Black Sea and Caspian regions (Mabuchi, 2009, p. 36).

The establishment of the "GUAM plus Japan" dialogue was a practical result of the introduction of the "Arc of Freedom and Prosperity". Japan's support for GUAM - a regional forum set up in 1997 by Ukraine, Azerbaijan, Georgia and Moldova to promote democracy and market economics, and institutionalized in 2007 - was a logical continuation of the democratic wave that embraced Japan's foreign policy. In 2007, the first meeting of the "GUAM plus Japan" dialogue took place in Baku, and the second meeting, dedicated to the anniversary of the founding of GUAM, was held in Tokyo with the participation of national coordinators, the Secretary General of the organization, and representatives of the Japanese government, political and scientific circles. In 2008, "GUAM plus Japan" meetings continued at the Batumi Summit and during the OSCE Ministerial Council in Helsinki. The fourth meeting of GUAM and the Japan's Foreign Ministry was held in Tokyo in 2009. The main focus of the discussions was energy, transport, environmental protection, investment, trade and peaceful conflict resolution in accordance with UN Security Council resolutions.

After the victory of the Democratic Party of Japan in the 2009 elections, certain conceptual changes were observed in Japan's foreign policy. Prime Minister Hatoyama Yukio proposed the concept of "yuai", which can be translated as "fraternal love" and is associated with the ideas of the French Revolution "liberté", "egalité" and "fraternité". According to this concept, Y. Hatoyama positioned Japan as a "bridge" between East and West, between rich and poor countries, as well as between different civilizations. Given the priority of the Asian dimension of Japan's foreign policy for the Hatoyama government, it was also intended to improve relations with China and create the East Asian Community (Stewart, 2009).

With the return of the Liberal Democratic Party to power in 2012, the emphasis on the democratic direction of Japan's foreign policy was restored and support for democratic organizations such as GUAM was further strengthened. In his speech "The Bounty of the Open Seas: Five New Principles for Japanese Diplomacy" in 2013, Prime Minister of Japan Abe stressed the importance of "universal values", emphasizing the need to protect freedom of thought and speech (The Bounty of the Open Seas, 2013). The 2013 National Security Strategy enshrined "maintaining and protecting the international order based on universal values" as one of Japan's national interests (National Security Strategy, 2013).

Such events contributed to the fact that, in 2013 and 2015, new meetings of the "GUAM plus Japan" forum took place in Tokyo, where the parties 
exchanged views on various issues of mutual cooperation, in particular on water resources management, energy security, tourism and international relations. In 2015, the Japan-GUAM Cooperation Program was adopted, outlining the main objectives of cooperation such as "consultations on broad range of actual problems of international and regional relations in order to maintain international peace and security on basis of the UN Charter, generally recognized principles and norms of international law, particularly those related to the sovereignty and territorial integrity of states" (GUAM, 2018). Thus, the issue of the occupation of Crimea by Russia was included in the agenda of "GUAM plus Japan".

Cooperation within this structure was also fostered through meetings between foreign ministers which took place in 2008, 2011, and 2015-2019. In addition, a number of seminars and workshops were held on topics such as energy security, health care, water resources management, investment cooperation, transport, tourism and agricultural development.

The introduction of the "Arc of Freedom and Prosperity" was an important step for the development of Japan's relations with the states of the Black Sea region; by virtue of this initiative, the geographical gaps in Japan's foreign policy strategy were filled. Japan's support for GUAM through the "Arc of Freedom and Prosperity" has given this organization more confidence in the development of democratic institutions. Japan's introduction of "value-oriented diplomacy" has also improved Japan's relations with Ukraine and strengthened our country's position in the international arena.

Another important factor that contributed to the deepening of Japan's relations with the BSEC was the establishment of a new mechanism of international expert and political cooperation - the "Japan - Black Sea Area Dialogue". In 2005, the first meeting of the forum on "Peace and Prosperity of the Wider Black Sea Area and Japan's Role" was held in Tokyo under the auspices of the Ministry of Foreign Affairs of Japan, the research institute the "Global Forum of Japan", and one of the leading Japanese newspapers, the Yomiuri Shimbun. Further meetings were held in 2007 ("Japan and Black Sea Area in the Rapidly Changing World"); 2010 ("Prospects of Changing Black Sea Area and Role of Japan") and 2013 ("How to Develop Japan and Black Sea Area Cooperation"), in which participants discussed the "Arc of Freedom and Prosperity" and the prospects for cooperation between Japan and the region.

On the Ukrainian side, these meetings were attended by Ambassadors of Ukraine to Japan Y. Kostenko in 2005 and M. Kulinich in 2007 and 2010. At the third meeting, M. Kulinich participated as the main speaker with a report on "Addressing the Challenges to Economic Development in the Black 
Sea Area: a Ukraine's vision". In 2013, Ambassador of Ukraine for Special Assignments M. Melenevsky co-chaired the "Japan - Black Sea Area Dialogue".

The Japanese academic community, represented by professors S. Mutsushika (Shizuoka University), Y. Hasumi (Rikkyo University), Y. Hirose (Keio University) and others, actively advocated for the development of Japan's relations with the Black Sea region, emphasizing the need for cooperation between Japan and the EU, Russia, the United States, the importance of attracting new players to reduce the dependence of the BSEC countries on traditional partners, as well as the experience that Japan can share with the Black Sea states as an Asian nation.

Following the recommendations proposed during the abovementioned forums, Japan became the BSEC's Sectoral Dialogue Partner in 2010. This status is flexible and does not limit the dialogue to any specific subject. Representatives of Japan may attend meetings, observe discussions of working groups in the BSEC member states, and participate in high-level councils such as meetings between foreign ministers.

Japan's cooperation with the BSEC includes the following: in 2012, BSEC Secretary General Victor Tvircun paid a courtesy visit to Parliamentary Vice-Minister for Foreign Affairs Hamada Kazuyuki in Tokyo; in 2013, the BSEC and Japan held a seminar in Istanbul on disaster prevention measures in Japan, organized within the framework of the cooperation between the BSEC and Japan as its Sectoral Dialogue Partner; and in 2020, BSEC PERMIS Secretary General Michael Christides held meetings with Heads of Missions of SDPs, including Japan, in Ankara.

An analysis of the aforementioned events gives grounds to note the leading role played by the academic community in the institutionalization of Japan's relations with the BSEC and to emphasize the importance of such events in the future. The joint work of the political elite with researchers allows for an exploration of the full range of areas of cooperation, as well as the establishment of direct contacts between the stakeholders, which is especially important for multilateral cooperation. In Japan's case, the introduction of the "Arc of Freedom and Prosperity" against the background of the development of academic and political dialogue has become an example of the successful achievement of its foreign policy objectives.

\section{The current stage in Japan's relations with the Black Sea region}

The temporary occupation of the Crimean peninsula by the Russian Federation in 2014 opened a new stage in Japan's cooperation with the Black Sea region, particularly with Ukraine. On March 18, 2014, the Japanese Minister for Foreign Affairs Kishida Fumio made a statement in which he in- 
dicated that the referendum in Ukraine's Crimea violated the Constitution of Ukraine and had no legal force, and that the government of Japan would therefore not recognize its results (Statement by the Minister for Foreign Affairs of Japan, 2014). On March 19, S. Abe stated that Russia's recognition of Crimea's independence and the signing of an agreement on Crimea's accession to Russia violated Ukraine's unity, sovereignty and territorial integrity. He also stressed that Japan would not ignore attempts to change the status quo by force (Speeches and Statements by the Prime Minister, 2014).

Prior to these events in Ukraine, Japan under the leadership of Prime Minister Abe had aimed to achieve a historic breakthrough in relations with Russia. However, the crisis in Ukraine and sanctions against Russia by the G7 called into question the realization of Japan's plan for Japanese-Russian relations. As an active player in international relations advocating strict adherence to international law, Japan supported Ukraine's territorial integrity and imposed sanctions on Russia.

The first wave of sanctions against Russia was announced by Japan in March of 2014. Chief Cabinet Secretary Suga Yoshihide stated that Japan would suspend negotiations with Russia on the abolition of visa restrictions, investment cooperation, the use of outer space for peaceful purposes and the prevention of dangerous military activities. In 2014, Japan suspended the issuance of entry visas to Russian citizens who were involved in the violation of the sovereignty and territorial integrity of Ukraine. It also imposed sanctions on the Crimean companies "Chornomornaftogaz" and "Feodosia", as well as on five Russian banks, and tightened restrictions on arms exports to Russia. These sanctions were further extended.

In June of 2015, Prime Minister Abe visited Ukraine. It was the first visit of Japan's leader to our country. During talks with President Poroshenko, the Prime Minister of Japan made it clear that the Japanese government would not tolerate any attempts to change the status quo by force and that Japan supported the principle of Ukraine's sovereignty and territorial integrity. He stressed the importance of adhering to the Minsk agreements and promised to play an active role in achieving a peaceful settlement of the situation in Ukraine at the G7 summit in Japan in 2016. During his visit to Ukraine, S. Abe announced the provision of financial assistance to Ukraine in the amount of 1.85 billion USD (Udovik, 2020, p. 77).

In accordance with the agreements reached during the visits of S. Abe to Ukraine in 2015 and P. Poroshenko to Japan in 2016, Japan led the discussion on the situation in Ukraine during its presidency at the G7 summit on Ise Island in Mie Prefecture in May of 2016. The summit participants adopted a declaration in which they condemned Russia's occupation 
of Crimea and reaffirmed the course of continuing international sanctions against it. During the press conference, Prime Minister Abe touched upon the problems of the world economy and, among the international conflicts, singled out first and foremost the Ukrainian issue. He asserted the need for a diplomatic settlement of the situation in Ukraine, the importance of implementing the Minsk agreements, and the requirement that Russia take a constructive position.

It is important to emphasize that Japan is the only Asian country that has officially condemned Russia's actions in Ukraine and imposed international sanctions against it. This position of Japan was clearly reflected in its support for Ukraine in the UN. Japan supported the UN General Assembly resolutions on the Territorial Integrity of Ukraine adopted on March 27, 2014 (68/262), as well as those on the Situation of human rights in the Autonomous Republic of Crimea and the city of Sevastopol (71/205) adopted on December 19, 2016, in which Russia was recognized as an occupying power and Crimea as a temporarily occupied territory. Japan also co-sponsored the UN General Assembly resolutions with the same title adopted on December 19, 2017 (72/190) and December 22, 2018 (73/263).

During the adoption of the resolution on the territorial integrity of Ukraine, the Japanese representative to the UN Yoshikawa Motohide stated that "the Russian Federation's recognition of the Autonomous Republic of Crimea's independence, along with its illegal attempt to annex Crimea, represents infringement on the unity, sovereignty and territorial integrity of Ukraine" (Statement by H.E. Ambassador Motohide Yoshikawa, 2014). Japan's position also includes the contention that Russia's actions are a violation of the principles of the UN Charter and pose a serious challenge for the entire international community.

In continuation of this policy, after the capture of Ukrainian ships on the Black Sea by Russia on November 25, 2018, Japan supported the UN General Assembly's resolutions on the "Problem of the militarization of the Autonomous Republic of Crimea and the city of Sevastopol, Ukraine, as well as parts of the Black Sea and the Sea of Azov" adopted on December 17, 2018 (73/194) and December 9, 2019 (74/17).

It is believed that a significant reason for Japan's support of the status quo and non-recognition of its alteration by force is the situation unfolding in the region of the Senkaku Islands (known in China as the Diaoyu Islands), located in the East China Sea. According to Japan's position, these islands were incorporated into Japan in 1895 and, after World War II, they came under US control in accordance with the San Francisco Peace Treaty. It is stated that, in 1972, the United States returned the Senkaku Islands to Japan along with 
Okinawa and, in 2012, the Japanese government purchased three additional islets of this ridge.

However, this position is not supported by China, which announced in 2013 that it would create an "East China Air Defense Identification Zone" which included the Senkaku Islands. The 2019 Japanese Defense White Paper also states that "Chinese government vessels continually violate Japanese territorial waters, and Chinese naval ships continuously operate in waters around the Islands" (Defense of Japan, 2019, p. 44). It also mentions that, in 2016, a Chinese Navy combatant vessel entered Japan's contiguous zone around the Senkaku Islands for the first time and, in 2018, a Chinese submarine also did so (same as above, p. 71-72).

According to Mitsui Institute scholar D. Kitade, the illegal occupation of the Crimean peninsula by Russia creates a "dangerous precedent" that could have global consequences and negatively affect Japan's security. The possibility of reproducing such a scenario in the region around China has prompted Tokyo to seek condemnation of Russia's actions by the international community. D. Kitade also notes that due to intensification of China's activities in the East China Sea, including attempts to restrict air traffic around these islands, Japan has emphasized the importance of implementing a policy of "open and stable seas" (Kitade, 2020).

Some experts, such as Niigata University professor S. Hakamada, point to a "dilemma" in Japan's foreign policy over the need to act in sync with the US regarding the imposition of sanctions on Russia due to its occupation of Crimea and, at the same time, its efforts to improve Japanese-Russian relations (Mizuho, 2014). The official position of the government of Japan on this issue was expressed by the Ambassador of Japan to Ukraine Sumi Shigeki (2014-2019), who noted that the position of Japan is that Russia's actions against Ukraine in Crimea and the Donbas should be separated from negotiations on the return of the Northern Territories. He claims that Japan will continue to refuse to recognize the "annexation" of Crimea and will be implementing anti-Russian sanctions as long as Russia's illegal annexation of Crimea continues (Hirano, 2018). Japan's support for Ukraine's territorial integrity and sovereignty was reaffirmed during a meeting between Ukraine's President V. Zelenskyy and Japan's Prime Minister S. Abe held during the Ukrainian President's 2019 visit to Japan to attend the Emperor's enthronement ceremony.

Ambassador Kurai Takashi (2019 - present), for his part, noted that the key to resolving territorial issues is the upholding of solidarity among the international community (Siruk, 2019). Therefore, further cooperation between Ukraine and Japan in this area is an important element in achieving the de-occupation of Crimea and its return to Ukraine. 


\section{The results of Japan's cooperation with the the Black Sea states}

The results of Japan's cooperation with the Black Sea states can be tracked in several areas. First of all, with the collapse of the Soviet Union Japan has been providing support to post-Soviet countries aimed at stabilization, democratization and the transition to a market economy. In total, Japan has granted 3 billion USD, including technical assistance such as accepting trainees from these countries and sending experts to them, emergency humanitarian assistance, and credits to facilitate trade and economic activities.

In addition to this bilateral assistance, Japan also participated in efforts to provide multilateral assistance to the countries of the former Soviet Union. It hosted the Tokyo Conference on Assistance to the New Independent States in October of 1992 and provided 20 million USD to the International Science and Technology Center, the main purpose of which is to promote cooperation with scientists of the newly independent states of the former USSR, and contributed to the 24 billion USD support package and cooperated in rescheduling of debts. Japan also actively provided technical assistance, food aid and financial support to further efforts toward reform in Central and Eastern Europe after the collapse of the Berlin Wall in November of 1989. Japan's assistance to the region amounted to approximately 4.5 billion USD in total (Objectives and Priorities of Japan's Foreign Policy, 1992).

Nowadays, Japan's attention is focused on providing support to ensure the development of democratic institutions and market economies in the Black Sea states on the basis of the "Arc of Freedom and Prosperity". In particular, Japan is concentrating its efforts on providing support to Ukraine and Moldova, the sustainable development of which is indispensable for the stability of the Black Sea region.

Since 2014, Japan has been steadily implementing assistance totaling 1.85 billion USD to Ukraine, which is one of the largest scales on an individual country basis. To support democracy in Ukraine, Japan held a Seminar on Knowledge and Experience Sharing (2015), provided the Economic Reform Development Policy Loan to support rebuilding the state's finances and carrying out a range of institutional reforms (2015-2016), and launched the Project for Capacity Development of the Public Broadcasting of Ukraine (2017). Through international organizations, Japan has provided assistance to improve the living standards of internally displaced persons and rebuild the infrastructure of eastern Ukraine.

With regard to the Caucasus region, which includes Armenia, Azerbaijan and Georgia, in 2018 the Japanese government launched "Japan's Caucasus Initiative", consisting of such pillars as "Assistance for Human Re- 
source Development for State Building" (training programs for self-sustained development) and "Assistance for Paving the Way to Appealing Caucasus" (infrastructure development and support for the improvement of the business environment).

That same year, Prime Minister Abe announced Japan's commitment to assisting in economic and social reforms in the Western Balkans region, which includes BSEC members such as Albania and Serbia, within the framework of the "Western Balkans Cooperation Initiative".

The development of infrastructure projects and economic ties with the Black Sea partners is another important direction for Japan's foreign policy in the region. Infrastructure and environmental protection assistance has been provided through the Japan International Cooperation Agency in the form of Official Development Assistance. Japan's government aid is designed to promote the economic development and welfare of developing countries. Major projects include the East-West Highway Improvement Project in Georgia, the modernization of the port of Bourgas and expansion of the Sofia metro in Bulgaria, the Bosphorus Rail Tube Crossing Project in Turkey, the Bucharest International Airport Rail Access Link Project in Romania, the Greater Tirana Sewage System Improvement Project in Albania, the Flue Gas Desulphurization Construction Project for Thermal Power Plants in Serbia, and the Boryspil State International Airport Development Project and Modernization of the Bortnychy Aeration Station in Ukraine. The top recipients of Japan's ODA in the Black Sea region as of the end of 2018, including loans, grant aid and technical assistance, were Turkey (7.483 billion USD); Ukraine (1.845 billion USD); Azerbaijan (1.148 billion USD); Serbia (672 million USD); Armenia (438 million USD) and Georgia (412 million USD) (Official Development Assistance, 2018).

In addition, Japan has made a significant contribution to the development of energy projects in the Black Sea - Caspian region, such as the development of a number of major oil and natural gas deposits in the Caspian Sea, the construction of the Baku - Tbilisi - Ceyhan oil pipeline, and a gas pipeline for transporting natural gas from Azerbaijan to Turkey via Georgia.

The largest trading partners of Japan among the BSEC countries, as of the end of 2019, are Russia (23.432 billion USD), Turkey (3.578 billion USD), Romania (1.480 billion USD), Ukraine (1.373 billion USD), Greece (1.208 billion USD) and Georgia (391 million USD) (Trade Statistics of Japan, 2020). The signing of economic partnership agreements will further intensify trade relations with the states of the region. (Currently, such an agreement has been concluded between Japan and the EU; Japan's negotiations with Turkey are in process.) 
In the area of international peace and security, Japan has traditionally expressed its position on developments in the Black Sea region through political statements, analysis of the current situation in the annual Diplomatic Bluebook and White Paper "Defense of Japan", and cooperation within international organizations. In addition to the Crimean issue, Japan took a clear position in support of Georgia's territorial integrity following Russia's recognition of Abkhazia and South Ossetia in 2008, called for a peaceful settlement of the Nagorno-Karabakh conflict on the basis of Azerbaijan's sovereignty and territorial integrity, declared non-recognition of elections in the so-called "LPR" and "DPR" in Ukraine in 2018, and supported the resolution of the UN General Assembly on Russian troops in Transnistria, Moldova "Complete and unconditional withdrawal of foreign military forces from the territory of the Republic of Moldova" (A/72/L.58) in 2018. At the same time, in 2008, Japan recognized the independence of Kosovo.

Japan has been promoting bilateral cooperation with the BSEC members in the area of security since the 2010s. In 2013, Japan's Parliamentary Vice-Minister of Defense Sato Masahisa visited Azerbaijan; in 2015, Japan's State Minister of Defense Sato Akira paid a visit to Bulgaria; and in 2017, Vice-Minister of Defense of Japan for International Affairs Manabe Ro visited Ukraine. The Japanese Minister of Defense Onodera Itsunori met the Minister of National Defense of Turkey Ismet Yilmaz to discuss defense cooperation in accordance with the "Statement of Intent between the Ministry of Defense of Japan and the Ministry of National Defense of the Republic of Turkey" of 2011. In 2015, the Japanese Minister of Defense Nakatani Gen met his counterpart from Georgia, Tinatin Khidasheli, in Tokyo.

Japan also launched bilateral security dialogues with two Black Sea regional powers - Ukraine and Russia. Consultations with Russia in the " $2+2$ " format with the participation of representatives from the ministries of foreign affairs and defense were launched in 2013. Following the occupation of Crimea, such consultations were put on hold, but were resumed in 2017, then held again in 2018 and 2019.

In 2018, "2+2" security consultations between Japan and Ukraine were held for the first time, resulting in the signing of the Memorandum on Cooperation and Exchanges in the Defense Sector. Japanese-Ukrainian security cooperation was further strengthened by a meeting between the Ukrainian Defense Minister Andriy Zagorodnyuk and Defense Minister of Japan Kono Taro at the Munich Security Conference in February of 2020. In 2020, Japan planned to take part for the first time in the Sea Breeze exercise, which is traditionally organized by Ukraine and the United States. However, due to the spread of the coronavirus these plans were cancelled. In addition, as of 
2018, Japan maintained a cybersecurity dialogue with eleven countries, two of which - Ukraine and Russia - are part of the Black Sea region.

The cultural and humanitarian dimension of international cooperation has been developing through the organization of cultural events, in particular the "Year of Japan" which was held in Greece (1999), Romania (2002), Turkey (2010), Ukraine (2017) and Russia (2018). Members of the Imperial Family of Japan visited Bulgaria, Greece, Romania, Russia and Turkey. The organization of such a visit to Ukraine is gaining more relevance as well. The Japanese government provides cultural grants and scholarships to study in Japan. Human exchanges are promoted by virtue of the establishment of a visa-free regime (EU, Serbia, Turkey) and visa relaxation for short-term visits to Japan (Ukraine, Georgia, Russia). Further prospects for cooperation are associated with the holding of the Olympic Games in Tokyo in 2021.

In the context of the global Covid-19 pandemic, Japan's government has decided to provide the drug Avigan, which may be effective in treating the coronavirus, to a number of countries including the Black Sea states, namely Ukraine, Albania, Bulgaria, Georgia, Moldova, Serbia and Turkey.

\section{Conclusions}

In conclusion, one can state that the development of Japan's relations with the Black Sea states took place in the context of the general expansion of Japanese diplomacy carried out by virtue of its transformation into a "normal country" that actively contributes to maintaining international peace and security, and was assisted by the development of Japan's relations with the European Union and post-Soviet countries. At the conceptual level, Japan's strategy with regard to the Black Sea region and Ukraine was formalized in the mid-2000s with the introduction of the "Arc of Freedom and Prosperity" as the fourth principle of Japan's foreign policy, which can be considered a logical continuation of the "Silk Road Diplomacy". An important role was played here by the Japanese community of experts in international relations, which actively promoted the idea of closer cooperation between Japan and the BSEC within the framework of the "Japan - Black Sea Area Dialogue". As a result, in 2010 Japan acquired the status of a Sectoral Dialogue Partner of this organization, shifting cooperation with the states of the region from the bilateral to the multilateral level. The occupation of the Crimean peninsula opened a new stage in Japan's relations with the Black Sea region, while Japan's unwavering support of Ukraine's sovereignty and territorial integrity, based on universal values and S. Abe's "active pacifism", reaffirmed its status as a global state.

Prospects appear positive for further cooperation between Japan and the Black Sea region. With the exception of the territorial dispute with Russia, Ja- 
pan has enjoyed friendly relations with the BSEC members, which provides a firm basis for their further development in the future. Japan is deeply involved in a dialogue with its Black Sea partners on both bilateral, regional and international levels on a wide range of issues, including support for democratization, economic cooperation, improvement of infrastructure and the environment, ensuring international peace and human security, and the strengthening of cultural and inter-societal ties. Japan's expertise as an active member of the UN and the G7 and its status as the world's third largest economic power, a technologically developed state, and one of the biggest international donors, provide vast opportunities for the stabilization of the region, as well as the promotion of prosperity and well-being among its people.

In addition, Japan's involvement in the international processes taking place in the Black Sea region has allowed it to broaden the horizons of its international outreach. With the introduction of the "Arch of Freedom and Prosperity" and adoption of the National Security Strategy, it succeeded in making sure that value-oriented diplomacy would become an important pillar of its foreign policy, as well as ensuring the continuation and integrity of its policies in the region from the Central Asia to the Black Sea, the Balkans and Eastern Europe. This strategy provides Japan with an opportunity to better understand the dynamics of regional affairs, including activities by such players as Russia and China; it confirms its leading role in fostering cooperation between Asia and Europe; and supports the case for Japan's bid for UN Security Council permanent membership.

One of Japan's closest partners in the Black Sea region is Ukraine - a country that shares the same universal values and approach to international relations. Bilateral ties between the two states are based on common interests in the region, such as promoting democracy and a market economy, as well as ensuring peace and security. Japan's support for Ukraine in the context of the illegal occupation of its territories by Russia, the increase in the amount of financial assistance from Japan to our country, and Japan's first ever decision to take part in naval exercise in the Black Sea are in line with the concept of a "Proactive Contribution to Peace" and confirm Japan's status as an active player in international relations. A continued strengthening of the synergy between Ukraine and Japan through such structures as the BSEC, "GUAM plus Japan" and OSCE, Ukraine's accession to ASEM, as well as Japan's support for Eastern Partnership, will contribute to the achievement of common goals and lead to better coordination of joint activities in the Black Sea region. The strengthening of the Ukraine-Japan tandem will also provide a further impetus for the development of cooperation between the Black Sea region and Asia. 


\section{References}

1. Defense of Japan. (2019). Ministry of Defense. Retrieved from https://www. mod.go.jp/e/publ/w_paper/wp2019/pdf/DOJ2019_Full.pdf

2. Gaimusho soshikirei (Decree on the structure of the Ministry of Foreign Affairs). Denshi seifu no sogo madoguchi (e-Government Portal) (2000). Retrieved from https://elaws.e-gov.go.jp/ (in Japanese).

3. GUAM-Japan Cooperation Program. (2015). GUAM. Retrieved from https:// guam-organization.org/en/guam-japan-cooperation-program/

4. Hirano, T. (2018). Shigeki Sumi, Posol Yaponii v Ukraini: zberegennya Yaponieyu sanktsii proty Rosii - pytannya pryntsypu ne lyshe dlya Krymu i Donbasu (Shigeki Sumi, Ambassador of Japan to Ukraine: Maintaining Japan's sanctions against Russia is a matter of principle not only for Crimea and Donbas). Ukrinform. Retrieved from https://www.ukrinform.ua/rubric-world/2606025sigeki-sumi-posol-aponii-v-ukraini.html (in Ukrainian).

5. Iwanaga, K. (2011). Japan's Paradigm Lost? In B. Edström (Ed.), Japan's Foreign Policy in Transition: The Way Forward for Japan as an International Actor in a World in Flux, 58-72. Singapore: Institute for Security and Development Policy. Retrieved from https://www.isdp.eu/content/uploads/images/ stories/isdp-main-pdf/2011_edstrom_japans-foreign-policy.pdf

6. Japan's Energy Supply Situation and Basic Policy. (2015). The Federation of Electric Power Companies in Japan. Retrieved from https://www.fepc.or.jp/ english/energy_electricity/supply_situation/

7. Kitade, D. (2020). The Butterfly Effect: Why Does Eastern Europe Matter to Japan? Retrieved from https://www.iss.europa.eu/content/butterfly-effect-why-does-eastern-europe-matter-japan

8. Mabuchi, M. (2009). Nihon kokka no "katachi" o motomete - nihon gaiko "saisei" e no teigen (In search of a "form" of the Japanese state - proposals for the "revival" of Japanese diplomacy). Diplomatic Forum, 5, 36-42 (in Japanese).

9. Market Intelligence. (2018). World Tourism Organization. Retrieved from https://www.unwto.org/es/market-intelligence

10. Mizuho, A. (2014). Ukraine crisis has Japan on horns of a dilemma. Stance against territory violations endangers closer ties with Russia. Retrieved from https://www.japantimes.co.jp

11. Mutsushika, S. (2007). Seisaku teigen: kokkai kyoryoku. Nihon no tai kokkai seisaku - "Jiyu to han'ei no ko" gaiko o motomete (Policy Recommendations: Black Sea Cooperation. Japan's policy in the Black Sea region - in quest of diplomacy of the "Arc of Freedom and Prosperity"). Retrieved from http:// www2.jiia.or.jp (in Japanese).

12. Mutsushika, S. (2017). Kokkai chiiki no kokusai kankei (International Relations of the Black Sea Region). Nagoya: Nagoya daigaku suppan (in Japanese).

13. National Security Strategy. (2013). Cabinet Secretariat. Retrieved from https://www.cas.go.jp/jp/siryou/131217anzenhoshou/nss-e.pdf

14. Objectives and Priorities of Japan's Foreign Policy. Section 2. (1992). Ministry of Foreign Affairs of Japan. Diplomatic Bluebook. Retrieved from https:// www.mofa.go.jp/policy/other/bluebook/1992/1992-1-2.htm 
15. Official Development Assistance (ODA). (2018). Ministry of Foreign Affairs of Japan. Retrieved from https://www.mofa.go.jp/policy/oda/data/index.html

16. Sakamoto, K. \& Kanehara, N. (2007). "Utsukushii kuni" no "shuccho suru gaiko" ga mezasu mono - shiminken kaifuku gaiko no jidai wa owatta (The goal of "beautiful country" - the end of the era of restoring rights as a member of the international community). Diplomatic Forum, 4, 18-27 (in Japanese).

17. Siruk, M. (2019). Dvi mety posla. Takashi Kurai: "Yaponiya hoche i nadali buty duje dobrym drugom i partnerom Ukraini" (The Ambassador's two goals. Takashi Kurai: "Japan wants to continue to be a very good friend and partner of Ukraine"). Day. Retrieved from https://day.kyiv.ua/ (in Ukrainian).

18. Soeya, Y., Welch, D., \& Tadokoro, M. (2011). Japan as a «Normal Country»?: A Nation in Search of Its Place in the World. Toronto: University of Toronto Press.

19. Speech by Mr. Taro Aso, Minister for Foreign Affairs on the Occasion of the Japan Institute of International Affairs Seminar "Arc of Freedom and Prosperity: Japan's Expanding Diplomatic Horizons”. (2006). Ministry of Foreign Affairs of Japan. Retrieved from http://www.mofa.go.jp/announce/fm/aso/ speech0611.html

20. Speeches and Statements by the Prime Minister. (2014). Prime Minister of Japan and His Cabinet. Retrieved from https://japan.kantei.go.jp/96_abe/statement/201403/0320kaiken.html

21. Statement by H.E. Ambassador Motohide Yoshikawa Permanent Representative of Japan to the United Nations at the Debate on the Situation in Ukraine. (2014). Permanent Mission of Japan to the United Nations. Retrieved from http://www.un.emb-japan.go.jp/statements/yoshikawa032714.html

22. Statement by the Minister for Foreign Affairs of Japan on the Measures against Russia over the Crimea referendum. (2014). Ministry of Foreign Affairs of Japan. Retrieved from https://www.mofa.go.jp/mofaj/press/danwa/ page4_000409.html

23. Stewart, D. T. (2009). How Japan's New Leader May Redefine the Nation. Newsweek. Retrieved from https://www.newsweek.com/how-japans-newleader-may-redefine-nation-80995

24. Trade Statistics of Japan. (2020). Japan Customs. Retrieved from https:// www.customs.go.jp

25. The Bounty of the Open Seas: Five New Principles for Japanese Diplomacy. (2013). Ministry of Foreign Affairs of Japan. Retrieved from https://www. mofa.go.jp/announce/pm/abe/abe_0118e.html

26. Udovik, V. (2016). Zovnishnya polityka Yaponii na postsovets'komu prostori (1991-2016) (Japan's foreign policy in the post-Soviet area (1991-2016). Skhid: Analytical and Information Journal, 5 (145), 56-63 (in Ukrainian).

27. Udovik, V. (2020). The Black Sea Area in Japan's Expanding Strategic Horizons. Ukraine Analytica, 1 (19), 72-79. Retrieved from http://ukraine-analytica.org/wp-content/uploads/Udovik.pdf

28. Uyama, T., Len, K., \& Hirose, T. (2009). Nihon no chuo ajia gaiko - tamesareru chiiki senryaku (Japan's Central Asian diplomacy: a test of regional strategy). Tokyo: Hokkaido Daigaku Suppan (in Japanese). 



\section{CONCLUSIONS}

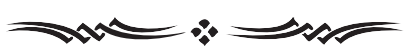


International trade, migration flows, and the struggle for strategic control over the region are all factors which determine the importance of the Black Sea region. Today, the interests and paths of large and small actors intersect in the Black Sea.

The EU in particular has become one of the key forces influencing the region's transformation. The EU is the largest trade and investment partner for all Black Sea countries. The Black Sea's potential in the fields of transport-transit and energy communication is an important aspect of the European economy. The EU's attention to the region is also linked to the presence of factors that negatively affect European security (such as conflicts, economic crises, political instability and organized crime). With the integration of Bulgaria and Romania, the European Union was to become one of the most important actors in the Black Sea; the Baltic States, Greece and Poland were particularly interested in strengthening the EU's role in the region. However, despite the existing interests and existing levers, the EU was wrong regarding the readiness of regional states to unite their efforts for the development of the Black Sea and regarding the influence of European initiatives on regional reform. Finally, the most serious problem was the inconsistency of positions within the Union itself on the importance of the region for Europe. In the future, this will threaten to turn the EU into a minor actor in the region, which will cause it to lose leverage over regional processes and render it capable of acting only with regard to humanitarian projects. Similarly, throughout the period under review, including the adoption of the NATO Strategic Concept in 2010, the Alliance did not see the Black Sea as a region that needed an integrated approach. Although three coastal states are members, NATO has not identified itself as part of the region. Only in 2014 was there a temporary shift in NATO's growing interest in the Black Sea. Today, therefore, the Alliance needs to articulate its future Black Sea strategy, identify risks and threats, and use its full potential for crisis management. The importance of such a reaction is due to the behavior of other actors, most notably the Russian Federation.

After the annexation of Crimea Russia turned the peninsula into a fortress of Russian power which was in turn projected into the region. The annexation of Crimea has made the Black Sea Fleet much more strategically important. In the future, the Black Sea Fleet may be more active in the Red Sea, the Persian Gulf, and even the Arabian Sea. In the future, this could lead to the use of nuclear weapons for de-escalation if Russia's conventional deterrence is not effective enough to deter the West from direct military intervention. The armament potential of the Russian Black Sea Fleet is growing; Russia will continue to use the Black Sea to expand its influence in neighboring regions, including the Balkans, the Middle East and the Mediterranean. In the 
Mediterranean, Russia identifies many threats to its security and to its influence in the Syrian conflict. Russia in turn threatens to use its power to deny (or substantially restrict) NATO military exercises in the region, which would mean the gradual transformation of the Black Sea into a "Russian Lake".

The existence of a number of joint Turkish-Russian projects in the strategic spheres of the defense industry, nuclear energy and the military-industrial complex plays an important role in continuing Turkey's balance between Russia and the West. On the other hand, the level of trust between Ankara and Moscow is quite low. Increasing Russia's military strength is not in Ankara's interests, so Turkey will pay more attention in the future to developing close cooperation with Ukraine and Georgia, as well as other small Black Sea countries.

"Pragmatic balancing" is a cornerstone of regional policy not only in Turkey but also in the so-called "third powers": Japan and China. Interaction with them is not a threat to Russian policy, for example, in Armenia, but it provides Yerevan with some room to maneuver and a stronger position in bilateral talks with the Kremlin. The growth of arms exports from Russia to Azerbaijan and the armed actions in Nagorno-Karabakh in 2016 and 2020 are forcing Armenia to diversify its future policy. As relations with Turkey have gone cold, almost the only serious non-systemic player that Armenia can interact with is China. Georgia has also managed to build a close strategic partnership with China. By attracting investment, abolishing visas and seeking closer ties with non-systemic states, Georgia is trying to offset tensions with Russia. Tbilisi sees Chinese investment as additional protection against Russia's policies in the region. Moldova and Azerbaijan currently have the least developed relations with "third powers", but their potential should not be underestimated. A politically aggressive but economically weak Russia has effectively forced the Black Sea countries to strengthen China's influence in the region. Developing economic ties with China will protect against the excessive influence of strong neighbors, but could potentially also undermine their engagement with the EU if China continues to provide loans and grants free of political conditions and criteria. Although the One Belt, One Road project is described by China exclusively in economic terms, if implemented, the initiative is likely to strengthen China's political influence and could change the balance of power in the Black Sea region.

Ukraine's relations with China are mainly focused on trade and the economy, especially in the military-technical and agricultural spheres. Kyiv's partnership with "third forces" serves several purposes: access to new markets, attracting new investments, diversifying energy sources, providing support in non-recognition of the annexation of Crimea, respect for the rights of 
Crimean Tatars and restoring Ukraine's territorial integrity. Although Ukrainian diplomacy remains largely focused on cooperation with the EU and the United States, Ukraine seeks to develop relations with "third powers" as a way to strengthen its own resilience to Russia's policies. In general, Ukraine's policy in the Black Sea is not so much a history of finding paths to an effective model of interregional economic cooperation, as it is a history of tactical victories, strategic mistakes, and unrealized opportunities. As Ukraine works to implement the Black Sea vector its foreign policy, its political leadership faces the extremely important task of "working on mistakes" and drawing conclusions from previously untapped opportunities. The development of a long-term strategy for the return of the Crimean Peninsula to Ukraine's sovereignty is impossible without taking into account several key factors that will influence the state's policy. First, modern energy strategies will form a new geo-economic regional spatial reality: the Black Sea-Caspian region. Regional actors stand ready to defend their interests fiercely; but now, so too do non-regional actors, including energy TNCs, which have long been present in the hydrocarbon market in the Black and Caspian Seas. The issue of Black Sea security affects not only the military component, but also economic security, which is challenged by growing global competition and protectionism. Secondly, the Black Sea can be considered to be one of the most dangerous regions of the world with a high level of conflict; it is increasingly associated with the beginning of a new Cold War. As a result, the Black Sea region automatically becomes a working studio for the "breaking-in" of new security models that will operate in the medium term. Russia's transformation of the Crimean Peninsula into a military fortress has resulted in a corresponding initiative by NATO to deploy missile defense elements in Romania and Turkey. Ukraine, like the whole region, is becoming a potential hostage to this situation. Third, the geopolitical competition shifts to the plane of cultural value clashes. The penetration of democratic traditions in the Black Sea is superimposed over the lack of historical experience in the implementation of democratic values, and all Black Sea states are experiencing a dramatic process of mental change or even break. This complicates the process states' foreign policy decisions, especially those which have such limited resources as Ukraine.

A study of the policy of the main actors in regional relations has led to the conclusion that the concept of a "Black Sea region" is gradually gaining a purely geographical meaning. For the Black Sea, in terms of economic, political and ideological development, belonging to subsystems (such as the Central and Eastern Europe, North Eastern Europe, and South Eastern Europe) is more important than belonging to a larger Black Sea system. There 
are few regions of the world with such internal contradictions. The explanation lies in the degree of growing issues in the relations of neighboring countries with different, and sometimes opposite, national interests: Russia and Ukraine, Russia and Turkey, Russia and Moldova, Russia and Georgia, Turkey and Greece, and Azerbaijan and Armenia. Although the multiplicity of contradictions in the Black Sea has a negative impact on all actors, it primarily impacts the small countries of the region (in which "small" should be determined not by the size of the country, but by the size of its economic and political resources). The voice of small countries is not heard in the Black Sea; these include Ukraine. Thus, the Black Sea's dysfunction objectively affects the general dysfunction of Ukrainian foreign policy; this is a serious concern, as the Black Sea was identified as the main platform upon which our country aimed to create an alliance of small states which could, while united, successfully protect their interests. At the present time, the chance of accomplishing this goal can be considered almost lost.

In the future, the development of the region will be determined by two regional leaders: Turkey and Russia; both of which will find that their successes in defending their own interests will be indirectly proportional to the coherence of the policies of the EU and NATO. At the same time, if Russia mainly relies upon the tools of brute force, Turkey will become a regional leader in all spheres of socio-political life relying both on sources of domestic growth and successful cooperation with non-systemic actors, the largest of which is China. It is the scenario of Turkey-China cooperation in the region that is the most plausible and acceptable for the vast majority of Black Sea actors. 

ABOUT THE CONTRIBUTORS

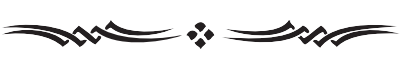


BRUSYLOVSKA Olga, Prof. (2012), Dr (Political Science, 2008). She has been working at Odesa Mechnikov National University (ONU) since 1991; Chair of the International Relations Department since 2015. She defended her Doctoral Thesis (specialisation - Political Problems of International Systems and Global Development) at the Institute of World Economy and International Relations (Kyiv), on the topic "Political-Systemic Transformation in the Region of Eastern Europe (1989-2004)". She is an author of more than 80 academic publications, including the monograph "Post-communist Eastern Europe: External Impact, Internal Changes" (Odesa, 2008); revised and enlarged edition "Systemic Transformation of the Region Eastern Europe (1989-2004)" (Saarbrücken, 2016). She is a member of editorial board of the academic journals: "International and Political Studies" (Odesa, Ukraine), "Political Life" (Vinnycia, Ukraine), "Politology Bulletin" (Kyiv, Ukraine), "Transformations" (Warsaw, Poland), electronic academic journal "Rhetoric and Communication" (Sofia, Bulgaria); a member of Review's Board of the academic journal "Strategic Review" (Poznan, Poland).

E-mail: brusylovska@onu.edu.ua

DUBOVYK Volodymyr, Associate Prof. (2000), PhD (Political Science, 1996). He has been working at Odesa Mechnikov National University since 1992. He is the Director of the Centre for International Studies at ONU (1999). He defended his PhD thesis (specialisation - Political Problems of International Systems and Global Development) at ONU on the topic "U.S. Policy towards Ukraine (1991-1996): Analysis of Foreign Policy Concepts". $\mathrm{He}$ is the author of more than 50 academic publications.

E-mail: volodymyrdubovyk@gmail.com

GABER Yevgeniya, PhD (Political Science, 2014), is a Deputy Director of the Hennadii Udovenko Diplomatic Academy of Ukraine at the MFA since 2018. She has previously worked as Assistant Professor at the International Relations Department of Odesa Mechnikov National University (2009-2014) and second secretary (political affairs) in the Ukrainian Embassy in Turkey (2014-2018). Dr. Gaber defended her PhD thesis (specialisation - Political Problems of International Systems and Global Development) in Kyiv National Shevchenko University on "The Turkish-US Relations in the Post-Cold War Era: Regional Dimensions". She is an author of more than 40 academic publications and co-author of several monographs on the matters of the Black Sea regional security, Middle Eastern studies, Turkish and Ukrainian foreign policy.

E-mail: yev.gaber@gmail.com 
GLEBOV Sergii, Associate Prof. (2008), PhD (Political Science, 2002). He has been working at Odesa Mechnikov National University since 1999; Deputy Director of the Institute of Social Sciences; Senior Research Fellow at the Centre for International Studies at ONU. He is a political observer, an author and an anchorman of a regular TV and Radio political shows for the media outlet "GLAS". He defended his PhD thesis (specialisation Political Problems of International Systems and Global Development at ONU on the topic "Constructing Security and Cooperation System in the Black Sea Region and the Role of Ukraine in this Process (1990s)." He is the author of more than 60 academic publications.

E-mail: sergglebov@gmail.com

KOVAL Igor, Prof. (2001), Dr (Political Science, 2000); Honoured Science and Technology Figure of Ukraine. He has been working at Odesa Mechnikov National University since 1978; Chair of the International Relations Department (1999-2015); Director of the Institute of Social Sciences (1996-2010); Rector of ONU since 2010. He defended his Doctoral Thesis (specialisation - Political Problems of International Systems and Global Development) at the Institute of World Economy and International Relations, Ukrainian Academy of Sciences, on the topic "Conceptualization of the US East European Politics at the Beginning of the Global Transformation Process". He is the author of more than 80 academic publications, including the monograph "The Last Battle of the Cold War: The Eastern European Policy of the Superpowers in Concepts of the Western Political Science (1980s - beginning of 1990s)".

E-mail: rector@onu.edu.ua

MAKSYMENKO Iryna, PhD (Political Sciences, 2014), Assistant Prof. of the International Relations Department (since 2009), Senior Research Fellow of the Centre for International Studies at the ONU (since 2001). In 2003, she took the position of Assistant Lecturer under the Civic Education Project on the premises of ONU. In 2004-2015, she was a Senior Research Fellow at the Odesa Regional Branch of the National Institute for Strategic Studies. She defended her PhD Thesis in the specialty 23.00.04 - "Political Problems of International Systems and Global Development" at the Y. Fedkovych Chernivtsi National University on the topic «Impact of the Great Britain, France and Germany on the European Politics Making: Economic, Foreign and Security Policy Dimensions». She is the author of more than 30 scientific publications.

E-mail: ira.maksymenko@gmail.com 
SHELEST Hanna, PhD (Political Science, 2012). Member of Board at the Foreign Policy Council "Ukrainian Prism". She defended her PhD thesis (specialization - Political Problems of International Systems and Global Development) at the Institute of World Economy and International Relations, Ukrainian Academy of Sciences, on the topic "Institute of Mediation in the Process of Peace Settlement of Military Conflicts". From 2004 to 2015 worked as a Senior Researcher at the National Institute for Strategic Studies under the President if Ukraine, Odesa Branch. In 2014 was a Visiting Research Fellow at NATO Defence College in Rome. Editor-in-Chief at English language analytical journal «Ukraine Analytica». Chief Editor of the Annual "Scorecards of the Foreign Policy of Ukraine". She is the author of more than 50 academic articles and numerous policy reports for the governmental institutions in Ukraine and abroad on security issues, conflict resolution, hybrid threats and the Black Sea Cooperation.

Email: shelest@prismua.org

SINOVETS Polina, Associate Prof. (2008), PhD (Political Science, 2004). She has been working at Odesa Mechnikov National University since 2000. She defended her PhD thesis (specialisation - Political Problems of International Systems and Global Development) at the Institute of World Economy and International Relations, Ukrainian Academy of Sciences, on the topic "Nuclear Deterrence in the Policies of the USA and Russia in the Post-Bipolar Period". She has been the Head of Odesa Centre for Non-proliferation at ONU since 2015. She is the author of more than 70 academic publications.

E-mail: polina.sinovets@gmail.com

UDOVIK Violetta, $\mathrm{PhD}$ (History, 2018). Recipient of scholarship from the Ministry of Education, Culture, Sports, Science, and Technology of Japan ("Research Student" program, 2009-2012). Obtained a degree of Master of Law from the University of Tokyo (Japan), where she took courses on the history of foreign policy of Japan and international relations in the Asia-Pacific region. Defended her PhD thesis (specialization - World History) on "Japan-Ukraine relations (1991-2016)" at Odesa Mechnikov National University. She is the author of more than 20 academic publications and media articles, including in Japanese. Academic fellow of the Institute for Languages and Cultures of Europe and Asia (Japan).

E-mail: violettaudovik@yahoo.co.jp 


\title{
Editors:
}

Brusylovska Olga,

Dubovyk Volodymyr, \&

Koval Igor

\section{BLACK SEA REGION IN WORLD POLICY: ACTORS, FACTORS, AND SCENARIOS OF THE FUTURE}

\author{
Monograph \\ In the author's version on
}

Text layout: S. A. Ostapenko

Signed in Print 30.11.2020. Format 60x84/16.

Conv. pr. Sheets 10.23. Circulation of 100 copies.

Order № 2181.

Publisher

Odesa I. I. Mechnikov National University

Ukraine, 65082, Odesa, Elisavetyns'ka str. 12

Tel. (048) 723-28-39. E-mail: druk@onu.edu.ua

Certificate of state registration of the print media DK № 4215 dated November, 22, 2011

\section{Editor}

Ukraine, Odesa 65009 Zooparkova str. 25

Tel. 3805077759 01; 38 (048) 7959160

E-mail: fenix-isd@ukr.net

Certificate of state registration of the print media DK № 1044 dated August, 17, 2002 
